\title{
ANÁLISE DA PRESCRIÇÃo DE MEDICAMENTOS DOS \\ CIRURGIÕES-DENTISTAS QUE ATUAM NAS UNIDADES DE \\ SAÚDE DE CAMPO GRANDE, MS, 2000.
}

ELENIR ROSE JARDIM CURY PONTES

Tese de Doutorado apresentada à Faculdade de Saúde Pública da Universidade de São Paulo para obtenção do Grau de Doutor.

Área de concentração: Serviços de Saúde Pública

Orientadora: Prof ${ }^{\mathrm{a}}$. Dr ${ }^{\mathrm{a}}$. Sandra Maria Ottati Oliveira Nitrini 
Autorizo, exclusivamente para fins acadêmicos e científicos, a reprodução total ou parcial desta tese, por processos fotocopiadores. Assinatura: \&lerybontes

Data: $\quad 16 / 05 / 2002$

$42121 / 2002$ doc 


\section{AGRADECIMENTOS}

À Prof ${ }^{\mathrm{a}}$. Dr ${ }^{\mathrm{a}}$. Sandra Maria Ottati Oliveira Nitrini pela orientação prestada e pelo incentivo na realização deste trabalho acadêmico;

À Prof ${ }^{\mathrm{a}}$. Dr ${ }^{\mathrm{a}}$. Aracy Witt de Pinho Spinola, à Prof ${ }^{\mathrm{a}}$. Dr ${ }^{\mathrm{a}}$. Lia Luzitana Cardozo de Castro, à Prof ${ }^{\mathrm{a}}$. $\mathrm{Dr}^{\mathrm{a}}$. Maria Jacira Silva Simões, ao Prof ${ }^{\circ}$. Dr. Roberto Augusto Castellanos Fernandez, pela atenção dispensada e sugestões na correção final deste trabalho e;

A todos os pacientes, cirurgiões-dentistas, farmacêuticos, supervisores odontológicos e demais funcionários da Secretaria de Saúde de Campo Grande / MS, sem os quais não poderia ter realizado esta pesquisa. Em especial agradeço ao Ailton Diogo Morilhas Rodrigues, Antônio Pedro Vilela, Daiselene Baena Castilho, Édio de Figueiredo, Jacinta de Fátima Franco Machado, Maria Aparecida de Menezes Machado, Maria Cândia Nunes da Cunha, Valéria Rodrigues de Lacerda e Welington Moreira Mello. 


\section{RESUMO}

Pontes ERJC. Análise da prescrição de medicamentos dos cirurgiões-dentistas que atuam nas unidades de saúde de Campo Grande, MS, 2000. São Paulo; 2002. [Tese de Doutorado - Faculdade de Saúde Pública da USP].

Objetivo. Considerando que avaliações sobre consumo de medicamentos são relevantes para detectar possíveis problemas nos serviços de saúde, realizou-se um estudo para conhecer alguns aspectos em relação a prescrição odontológica e o uso de medicamentos. Métodos. Pesquisou-se uma população de cirurgiões-dentistas em unidades de saúde de Campo Grande, MS, Brasil. Foram realizadas quatro atividades: (a) questionário dirigido aos cirurgiões-dentistas $(\mathrm{n}=159)$ para obter dados relacionados ao ato de prescrever; (b) análise de prescrições odontológicas $(\mathrm{n}=509)$, a fim de detectar possíveis falhas de preenchimento e posologia, e conhecer o padrão de prescrição; (c) questionário dirigido aos pacientes $(n=324)$ das prescrições odontológicas analisadas, para checar se houve anamnese precedendo às prescrições; (d) análise dos prontuários destes pacientes $(n=509)$ para detectar prescrições inadequadas em relação à idade e ao estado de saúde. Resultados. Das respostas dos cirurgiões-dentistas (636) sobre situações simuladas de utilização de medicamentos, $29,6 \%$ estavam incorretas, não tendo sido constatada associação com os seguintes fatores: tempo de formado do profissional, cursos de pós-graduação, conteúdo de farmacologia oferecido na graduação, auxílio para prescrever (livros, guias etc.), cursos sobre farmacologia. Das prescrições analisadas, 78,8\% estavam com preenchimento incorreto e $74,5 \%$ com posologia inadequada. Aproximadamente dois terços dos pacientes não foram submetidos à anamnese, no entanto, 81,5\% do total, receberam explicações sobre os medicamentos prescritos. Ocorreram prescrições inadequadas para gestantes, lactantes, crianças, pacientes hipertensos, com distúrbios gástricos, diabéticos e asmáticos. $\mathrm{O}$ uso de antiinflamatórios nãoesteróides foi o padrão de prescrição. Conclusão. Recomenda-se um programa de monitoramento da utilização de medicamentos no serviço público.

Descritores: Prescrição de medicamentos. Prescrição na Odontologia. Avaliação da assistência odontológica. 


\section{SUMMARY}

Pontes ERJC. Análise da prescrição de medicamentos dos cirurgiões-dentistas que atuam nas unidades de saúde de Campo Grande, MS, 2000. [An analysis of the prescription of drugs by dentists practicing at state-run health care units in Campo Grande, MS, Brazil, 2000]. São Paulo (BR); 2002. [Tese de Doutorado Faculdade de Saúde Pública da Universidade de São Paulo].

Objective. Because assessments of drug consumption are relevant for detecting ongoing deficiencies in health care services, this investigation was aimed at providing knowledge on features of the prescriptions issued by dentists and on the use of drugs. Methods. The population studied was composed of dentists practicing at state-run health care units in Campo Grande, MS, Brazil. Four approaches were employed: (a) a questionnaire directed at dentists $(n=159)$, to gather data on their prescribing practice; (b) an analysis of dental prescriptions $(n=509)$, to detect possible faults in information and posology, and also to make prescription patterns evident; (c) a questionnaire directed at the patients $(n=324)$ of the prescriptions analyzed, to verify whether prescribing was preceded by anamnesis; (d) an analysis of these patients' records $(n=509)$, to identify inadequate prescriptions regarding age and health status. Results. Of 636 responses from dentists for questions on simulated situations of drug use, $29,6 \%$ were incorrect. No association, however, was found between these responses and any of the following factors: time elapsed since professional degree was awarded, graduation courses, pharmacology contents provided during the undergraduate course, use of prescribing aides (books, manuals, etc.) and several courses about pharmacology. Of the prescriptions analyzed, $78.8 \%$ were incorrectly written, and posology was inadequate for $74.5 \%$. Nearly two thirds of the patients did not subject by the anamnesis, although $81.5 \%$ of the total number, received explanations on the drugs prescribed. Inadequate prescriptions were found for pregnant and lactating women, for children, and for patients with hypertension, gastric disorders, diabetes, and asthma. The prescription pattern identified was that of nonsteroidal anti-inflammatories. Conclusion. A drug-use monitoring program is recommended for implementation in the setting of state-run health care services.

Descriptors: Drug prescription. Prescriptions in Dentistry. Dental care assessment. 


\section{ÍNDICE}

1 Introdução 1

1.1 Medicamento 1

1.2 Prescrição medicamentosa 3

$\begin{array}{ll}1.3 \text { Características das patologias odontológicas } & 6\end{array}$

1.4 Grupos farmacológicos mais utilizados na Odontologia 9

1.4.1 Analgésicos 9

$\begin{array}{ll}\text { 1.4.2 Antiinflamatórios } & 12\end{array}$

$\begin{array}{ll}\text { 1.4.3 Antimicrobianos } & 13\end{array}$

$\begin{array}{ll}1.5 \text { Interações medicamentosas } & 18\end{array}$

$\begin{array}{ll}1.6 \text { Pacientes especiais } & 20\end{array}$

$\begin{array}{ll}1.7 \text { Considerações finais } & 26\end{array}$

2 Objetivos $\quad 28$

$\begin{array}{ll}2.1 \text { Objetivo geral } & 28\end{array}$

2.2 Objetivos específicos 28

3 Método 29

$\begin{array}{ll}3.1 \text { Tipo de pesquisa } & 29\end{array}$

3.1.1 Instituição onde efetuou-se a pesquisa 29

3.2 Coleta de dados 29

3.2.1 Questionário dirigido aos cirurgiões-dentistas 29

3.2.2 Análise de prescrições odontológicas e questionário dirigido aos pacientes 31

3.2.3 Análise dos prontuários de pacientes 35

3.3 Análise estatística $\quad 36$

4 Resultados $\quad 37$

4.1 Questionário dirigido aos cirurgiões-dentistas 37

4.2 Análise de prescrições odontológicas e questionário dirigido aos pacientes 49

4.3 Análise dos prontuários de pacientes $\quad 55$

5 Discussão

5.1 Anos de formado, pós-graduação e tempo de serviço do cirurgião-dentista 62

5.2 Conteúdo sobre farmacologia oferecido na graduação e cursos $\quad 63$

5.3 Cursos recentes sobre prescrição, livros, guias, cartilhas e similares $\quad 64$ 
5.4 Guias ou similares sobre prescrição odontológica oferecidos pela

SESAU e protocolos de atendimento

5.5 Prescrições odontológicas 66

$\begin{array}{ll}5.6 \text { Medicamentos prescritos } & 69\end{array}$

5.7 Grupos terapêuticos e forma de apresentação dos medicamentos $\quad 74$

$\begin{array}{ll}5.8 \text { Tipo de prescrição } & 75\end{array}$

$\begin{array}{ll}5.9 \text { Anamnese } & 77\end{array}$

$\begin{array}{ll}5.10 \text { Pacientes especiais } & 80\end{array}$

5.11 Prescrições coincidentes $\quad 83$

5.12 Interações medicamentosas $\quad 84$

$\begin{array}{ll}5.13 \text { Prescrições inusitadas } & 85\end{array}$

6 Conclusões $\quad 86$

$\begin{array}{ll}6.1 \text { Conclusões } & 86\end{array}$

6.2 Sugestões $\quad 92$

7 Referências $\quad 95$

8 Bibliografia complementar $\quad 109$

9 Glossário $\quad 110$

Anexo 1 - Questionário dirigido aos cirurgiões-dentistas $\quad$ A1

Anexo 2 - Questionário dirigido aos pacientes $\quad \mathbf{A 6}$

Anexo 3 - Impresso para cópia e análise das prescrições odontológicas $\quad \mathbf{A 8}$

Anexo 4 - Posologia $\quad$ A9

Anexo 5 - Tabelas referentes ao questionário dirigido aos pacientes $\quad \mathbf{A 1 0}$

$\begin{array}{ll}\text { Anexo 6 - Ficha de atendimento odontológico } & \mathbf{A 1 2}\end{array}$ 


\section{ÍNDICE DE TABELAS}

Tabela 1 - Número e porcentagem de respostas dos cirurgiões-dentistas, segundo formação, tempo de trabalho, se realiza ou não plantões, SESAU/Campo Grande-MS, 2000.

Tabela 2 - Número e porcentagem de respostas dos cirurgiões-dentistas, segundo conhecimento sobre farmacologia na graduação, cursos e outros, SESAU/Campo Grande-MS, 2000.

Tabela 3 - Participação dos cirurgiões-dentistas em cursos sobre prescrição odontológica nos últimos 12 meses, carga horária e responsável pela promoção dos cursos, SESAU/Campo Grande-MS, 2000.

Tabela 4 - Número e porcentagem das respostas corretas e incorretas dos cirurgiões-dentistas, em relação a questões sobre medicamentos e posologia, SESAU/Campo Grande-MS, 2000.

Tabela 5 - Número e porcentagem de respostas corretas e incorretas dos cirurgiões-dentistas, em relação a questões sobre medicamentos e posologia, segundo formação, tempo de trabalho, se realiza ou não plantões, Campo Grande-MS, 2000.

Tabela 6 - Número e porcentagem de respostas corretas e incorretas dos cirurgiões-dentistas, em relação a questões sobre medicamentos e posologia, segundo conhecimento sobre farmacologia na graduação, cursos e outros, Campo Grande-MS, 2000.

Tabela 7 - Número e porcentagem de preenchimentos corretos e incorretos, em prescrições odontológicas de Unidades de Saúde de Campo Grande - MS, 2000 .

Tabela 8 - Número e porcentagem dos tipos de erros de preenchimento em prescrições odontológicas de Unidades de Saúde de Campo Grande - MS, 2000. 
Tabela 9 - Número e porcentagem de posologias corretas e incorretas, em prescrições odontológicas de Unidades de Saúde de Campo Grande - MS, 2000.

Tabela 10 - Número e porcentagem dos tipos de erros de posologia em prescrições odontológicas de Unidades de Saúde de Campo Grande - MS, 2000.

Tabela 11 - Número e porcentagem dos medicamentos em relação às prescrições odontológicas de Unidades de Saúde de Campo Grande - MS, 2000.

Tabela 12 - Número e porcentagem* dos medicamentos em relação às prescrições odontológicas, segundo grupos terapêuticos, nas Unidades de Saúde de Campo Grande - MS, 2000.

Tabela 13 - Número e porcentagem das prescrições odontológicas, segundo tipo de prescrição, nas Unidades de Saúde de Campo Grande - MS, 2000.

Tabela 14 - Número e porcentagem prescrições odontológicas, segundo a quantidade de medicamentos prescritos, em Unidades de Saúde de Campo Grande - MS, 2000.

Tabela 15 - Número e porcentagem das respostas em relação aos motivos que levaram os pacientes a procurarem o atendimento odontológico, em Unidades de Saúde de Campo Grande - MS, 2000.

Tabela 16 - Número e porcentagem de respostas dos pacientes, em relação a se o cirurgião-dentista perguntou sobre o estado de saúde, durante o atendimento odontológico, em Unidades de Saúde de Campo Grande - MS, 2000.

Tabela 17 - Número e porcentagem de respostas dos pacientes, em relação a se o cirurgião-dentista explicou sobre a utilização dos medicamentos prescritos, durante o atendimento odontológico, em Unidades de Saúde de Campo Grande - MS, 2000. 
Tabela 18 - Número e porcentagem de registros de enfermidades ou condições fisiológicas / anatômicas específicas de pacientes odontológicos, em prontuários de Unidades de Saúde de Campo Grande - MS, 2000.

Tabela 19 - Número de indicações de medicamentos inadequadas, em relação às enfermidades ou condições fisiológicas / anatômicas específicas dos pacientes odontológicos, em prontuários de Unidades de Saúde de Campo Grande - MS, 2000.

Tabela 20 - Número de indicações medicamentosas adequadas ou inadequadas, em relação às enfermidades ou condições de fisiológicas / anatômicas específicas dos pacientes odontológicos e faixa etária, em prontuários de Unidades de Saúde de Campo Grande - MS, 2000.

Tabela 21 - Número de respostas dos pacientes em relação a se o cirurgiãodentista perguntou sobre terem ou não algum problema de saúde, durante o atendimento odontológico, em Unidades de Saúde de Campo Grande - MS, 2000.

Tabela 22 - Número de respostas dos pacientes em relação a se o cirurgiãodentista perguntou sobre terem ou não passado mal ao utilizarem algum medicamento, durante o atendimento odontológico, em Unidades de Saúde de Campo Grande - MS, 2000.

Tabela 23 - Número de respostas dos pacientes em relação a se o cirurgiãodentista perguntou sobre estarem ou não utilizando algum outro medicamento, durante o atendimento odontológico, em Unidades de Saúde de Campo Grande - MS, 2000.

Tabela 24 - Número de respostas das pacientes em relação a se o cirurgiãodentista perguntou sobre estarem ou não grávidas ou amamentando, durante o atendimento odontológico, em Unidades de Saúde de Campo Grande - MS, 2000 . 


\section{ÍNDICE DE QUADROS}

Quadro 1 - Algumas interações farmacológicas nocivas de interesse para a Odontologia e os efeitos adversos.

Quadro 2 - Pacientes com condições fisiológicas / anatômicas específicas e precauções a serem tomadas, quando houver necessidade de prescrições odontológicas de medicamentos de uso sistêmico.

Quadro 3 - Pacientes com doenças sistêmicas e precauções a serem tomadas, quando houver necessidade de prescrições odontológicas de medicamentos de uso sistêmico.

Quadro 4 - Unidades de saúde selecionadas para análise das prescrições, segundo Distrito Sanitário da Secretaria Municipal de Saúde, Campo Grande MS, 2000.

Quadro 5 - Porcentagem de $C D(s)$ em relação à atitude de pedir autorização ao médico para utilizar medicamentos em pacientes com algum problema de saúde (pressão alta, diabetes, cardiopatias etc.), SESAU/Campo Grande- MS, 2000 .

Quadro 6 - Porcentagem de $\mathrm{CD}(\mathrm{s})$ em relação a pedir autorização para utilização de medicamentos em mulheres grávidas ou que estão amamentando, SESAU/Campo Grande-MS, 2000.

Quadro 7 - Porcentagem de $\operatorname{CD}(\mathrm{s})$ em relação a seguir ou não a autorização por escrito do médico, da prescrição de medicamentos para pacientes com problemas de saúde ou mulheres grávidas ou que estão amamentando, SESAU/Campo Grande-MS, 2000.

Quadro 8 - Porcentagem de $C D(s)$ em relação a ter ou não disponibilidade de dados sobre a saúde geral do paciente do prontuário médico da Unidade de Saúde, no momento do atendimento odontológico, SESAU/Campo GrandeMS, 2000. 
Quadro 9 - Porcentagem de $C D(s)$ que registram diagnóstico e medicamentos prescritos após o atendimento odontológico, SESAU/Campo Grande-MS, 2000.

Quadro 10 - Valores do Quiquadrado $\left(\chi^{2}\right)$ com a respectiva interpretação, para as variáveis aleatórias do estudo sobre prescrição de medicamentos, Campo Grande-MS, 2000.

Quadro 11 - Número de prescrições medicamentosas coincidentes de pacientes odontológicos, segundo tipo de coincidência, profissionais envolvidos e medicamentos utilizados, em prontuários de Unidades de Saúde de Campo Grande - MS, 2000.

Quadro 12 - Número de interações medicamentosas de pacientes odontológicos, segundo tipo de interação e profissionais envolvidos, em prontuários de Unidades de Saúde de Campo Grande-MS, 2000.

Quadro 13 - Número de casos inusitados de prescrição medicamentosa, em prontuários de Unidades de Saúde de Campo Grande - MS, 2000.

Quadro 14 - Medicamentos utilizados em atendimentos odontológicos e as respectivas posologias, Campo Grande - MS, 2000. 


\section{INTRODUÇÃO}

\subsection{Medicamento}

O medicamento* é uma substância utilizada para prevenir, reverter ou atenuar um dado processo patológico, e para que isto ocorra, o fármaco escolhido deve manter as concentrações terapêuticas junto ao sítio-alvo, sendo necessária a escolha adequada de doses, vias de administração $e$ intervalos entre doses (WANNMACHER e FERREIRA 1995a). Isto parece bastante objetivo, o profissional prescreve um medicamento e o paciente o utiliza até o momento da "cura".

No entanto, há vários fatores envolvidos no consumo de medicamentos, tais como: (a) fatores estruturais - educação, cultura, conhecimento específico, vontade política, legislação etc.; (b) fatores técnicos - informação, comércio de medicamentos, prática de prescrição, dispensação, administração de medicamentos, promoção de drogas etc.; e (c) fatores humanos - carreira profissional, conhecimento e experiência prática, envolvimento etc. (LEMBER e col. 1997, CARNEIRO e CASTRO 1998, WESTERLUND e col. 1999) .

Há também outros problemas, como por exemplo, a inclusão no comércio de medicamentos, de produtos inapropriados, caros ou dispensáveis, acarretando em aumento com gastos farmacêuticos (ROLLE e col. 1995, MADRID e col. 1998). Isto, sem dúvidas, tem um peso substancial em relação às verbas públicas destinadas à saúde, visto que no Brasil, ainda são inferiores ao que seria necessário. Segundo Foster (1988) citado por LINARES e col. (1995, p.38), tem sido demonstrado que a prescrição racional pode significar uma redução de pelo menos $50 \%$ dos gastos em medicamentos.

\footnotetext{
* As palavras em itálico constam do glossário.
} 
Com o uso de uma lista limitada de medicamentos essenciais no serviço público, os profissionais de saúde podem conhecer melhor cada medicamento, diminuindo as possibilidades de confusão na prescrição, melhorando a qualidade do tratamento dos pacientes, na medida que evita o consumo de medicamentos desnecessários, demasiadamente perigosos ou excessivamente caros. Há maiores facilidades de produção, visto que estes medicamentos não estão protegidos por uma patente, facilitando o abastecimento das unidades de saúde e o acesso pela população. Permite um controle fácil e a redução de gastos administrativos nos processos de distribuição e armazenagem (ARA e MARCHAND 1995).

FRESLE e WOLFHEIM (1997), estudaram 38 países, 25 em desenvolvimento e 13 desenvolvidos, em relação a se possuíam projetos de intervenção pública na educação para o uso racional de medicamentos, e com exceção da Austrália, nenhum país estava empreendendo algum programa neste sentido. Isto é talvez compreensível em países em desenvolvimento, devido a limites e restrições e problemas prioritários, na regulação e racionalização do setor farmacêutico, no entanto, é mais difícil de explicar em países desenvolvidos.

A Organização Mundial da Saúde estabeleceu uma série de recomendações, para garantir o acesso e o uso racional dos medicamentos, que podem ser aplicadas segundo a situação de cada país. São elas: estabelecer uma lista de medicamentos essenciais (baseada no tipo de unidades de saúde e nas prescrições usuais dos profissionais); capacitar os profissionais de saúde em relação ao correto uso dos medicamentos (vantagens dos medicamentos essenciais com nomes genéricos); facilitar para estes profissionais, informações objetivas sobre medicamentos, através de formulários terapêuticos, revistas, manuais etc.; informar a população, sobre os 
benefícios, as limitações e os riscos dos medicamentos; estabelecer e aplicar leis e normas para o controle do uso dos medicamentos; garantir a qualidade dos medicamentos; favorecer a produção de certos medicamentos essenciais no próprio país; e garantir a disponibilidade com um sistema adequado de aquisição e distribuição (ARA e MARCHAND 1995).

De acordo com CASTRO (1999), a farmacoepidemiologia no Brasil está em fase final de consolidação, e através de ações fundamentais de Saúde Pública, como a implantação do Sistema Nacional de Farmacovigilância e a difusão da terapêutica informada, será possível a concretização do uso racional de medicamentos, como prática imprescindível para a saúde e para a qualidade de vida da população.

\subsection{Prescrição medicamentosa}

Para que se tenha uma prescrição racional e correta, é necessário seguir os seguintes passos: (a) diagnóstico do problema de saúde ou enfermidade, através do exame do paciente; (b) avaliação da gravidade e evolução do problema ou enfermidade; (c) especificação de um tratamento; (d) escolha do medicamento mais apropriado, levando em conta efeitos desejados e não desejados, contra-indicações, forma farmacêutica, via de administração, dose, horário, duração do tratamento e preço; (e) fornecimento de informações, instruções e advertências ao paciente e (e) monitoramento da efetividade do tratamento (WORLD HEALTH ORGANIZATION 1994, ARA e MARCHAND 1995, LINARES e col. 1995).

Muitos fatores influenciam a prescrição de medicamentos, como a questão sócio-econômica e cultural da sociedade, a indústria farmacêutica, a formação e educação profissional, a comunicação entre profissional e paciente, a disponibilidade do medicamento, dentre outros, diante disto, é certo que uma prescrição inadequada tende a aumentar os riscos e diminuir os benefícios da utilização de medicamentos 
(YERRO 1993, PEPE 1994, CÁRDENAS e ISENRICH 1995, SIXEL e col. 1995, CARNEIRO e CASTRO 1998, RANALI e ANDRADE 1998, BENITES 1999).

SIMÕES e col. (1986), em um estudo sobre o consumo de medicamentos em Araraquara, SP, constataram que $57,9 \%$ dos medicamentos consumidos pela população estudada, foram adquiridos por prescrição médica e $11,97 \%$ devido a prescrições anteriores. Observaram então, que a prescrição medicamentosa pode ser considerada a principal porta de entrada para o consumo de fármacos.

No entanto, a utilização de medicamentos sem a prescrição médica ou odontológica, por indicações de amigos, familiares, ou na própria farmácia, tem sido alvo de investigações, visto que há uma tendência crescente para a automedicação (SIMÕES e col. 1986, CEME 1989, COSTA e col. 1992, LÓPEZ 1996, SOUSA 1996, FONSECA 1998, JONES 1999). Em Campo Grande (MS), há vários estudos neste sentido, podendo-se citar: SILVA (1998), COSTA (1999), ROSSINI e CASTRO (1999), CASTRO (2000). Pode-se dizer que, uma prescrição adequada por escrito, limita este tipo de consumo (RANALI e ANDRADE 1998).

A Lei $\mathrm{n}^{\circ} 5.081 / 66$, que regula o exercício da Odontologia no Brasil, dá competência legal ao cirurgião-dentista (CD) para prescrever medicamentos. No artigo $6^{\circ}$ II , lê-se o seguinte: "prescrever e aplicar especialidades farmacêuticas de uso interno e externo, indicados em Odontologia." Vale ressaltar que, se o cirurgiãodentista prescrever algum medicamento que não seja de uso odontológico, estará cometendo uma infração penal (exercício ilegal de profissão), prevista no Código Penal Brasileiro (Art. 282), constituindo também, em infração ética, conforme Código de Ética Odontológico em vigor (Art. $6^{\circ}$ III) (CARDOZO e CALVIELLI 1988, RAMOS e col. 1995). 
As formalidades das prescrições medicamentosas estão contidas na lei $n^{\circ}$ 5.991, de $17 / 01 / 73$, regulamentada pelo decreto $n^{\circ} 74.170 / 74$, que foi alterado posteriormente pelo Decreto $n^{\circ} 793 / 93$, também chamado de lei dos genéricos. São elas: prescrever o medicamento pela denominação genérica (é obrigatório nos serviços públicos, conveniados e contratados do Sistema Único de Saúde); escrever à tinta, de modo legível, observando a nomenclatura e sistema de pesos e medidas oficiais, com indicação de posologia e duração total do tratamento; escrever o nome, endereço do paciente (há o costume de colocar o endereço somente em receitas sob controle), data, assinatura do profissional e número de inscrição no respectivo Conselho Regional (quando estes dados não estiverem tipografados, no caso do papel receituário conter o timbre da instituição prestadora de assistência odontológica, o profissional deverá utilizar carimbo, ou escrever de forma legível, o nome completo e o número de inscrição no Conselho Regional) (CARDOZO e CALVIELLI 1988, RAMOS e col. 1995).

Quando se tratar de medicamentos entorpecentes ou a estes equiparados, e os demais sob regime de controle, deverá ser utilizada a "Notificação de Receita", isto é, um impresso que ficará retido na farmácia no momento da dispensação, segundo normas da portaria DIMED (Divisão Nacional de Vigilância Sanitária de Medicamentos, órgão do Ministério da Saúde) nº 28, de 13/11/86 (BERNABA 1982, CANTO PEREIRA e col. 1995).

$\mathrm{Na}$ Odontologia, a prescrição medicamentosa faz parte, de maneira significativa, da conduta clínica. SIXEL e col. (1995), entrevistaram 100 cirurgiõesdentistas e observaram que: $54 \%$ dos profissionais freqüentemente prescrevem medicamentos. De acordo com MENDES (1986), os cirurgiões-dentistas 
especialistas em cirurgia buco-maxilo-facial e os clínicos gerais são os que mais prescrevem.

Após a confecção da prescrição medicamentosa, o cirurgião-dentista deverá fornecer todas as explicações necessárias, em relação ao porquê da escolha de determinadas drogas e a forma de utilizá-las, evitando assim, que o paciente deixe de usá-las no primeiro sinal de melhora, prejudicando a evolução do tratamento, ou ao contrário, continue usando-as por tempo maior que o necessário, aumentando as chances de ocorrerem efeitos colaterais (CARDOZO e CALVIELLI 1988, LIFSHITZ 1995, THORNHILL e DUXBURY 1996).

O monitoramento do tratamento também é de responsabilidade do profissional que indicou a terapia medicamentosa. Se o paciente não retornar, é porque melhorou. Se houver continuidade dos sintomas, instruir para que o paciente retorne, a fim de avaliar as possíveis razões do fracasso do tratamento, tais como: (a) não foi efetivo; (b) não foi seguro, ocorrendo, por exemplo, efeitos colaterais; (c) não foi conveniente, por exemplo, o horário das doses foi muito difícil de seguir (WORLD HEALTH ORGANIZATION 1994).

Em relação aos efeitos colaterais dos medicamentos, segundo ARBENZ (1988), estes que podem ser mais graves que a própria doença que se quer tratar, portanto, é necessário sempre avaliar, durante a escolha de determinado medicamento, se os beneficios que serão alcançados no tratamento de determinada patologia, suplantarão os riscos provenientes da utilização do mesmo.

\subsection{Características das patologias odontológicas}

Os problemas decorrentes de patologias odontológicas são, principalmente: dor, infecção e inflamação. 
É comum a presença de dor, em todas as áreas da Odontologia, causadas por: infecções dentais, cáries dentárias, doença periodontal, aparelhos ortodônticos, dentaduras mal adaptadas etc., o próprio tratamento dentário em geral determina algum grau de desconforto ou dor (WANNMACHER e FERREIRA 1995d).

Segundo a Associação Internacional para o Estudo da Dor, a dor é subjetiva, isto é, um mesmo estímulo nocivo, exógeno (mecânico, químico, físico, biológico) e endógeno (inflamação, exposição de dentina, isquemia tecidual), pode produzir variados graus de dor em diferentes indivíduos (reatividade emocional à dor). Estes estímulos são recebidos pelo sistema nervoso, a nivel periférico, em terminações nervosas livres (nociceptores). Quando os tecidos estão normais e os estímulos são leves, não há resposta dos nociceptores, no entanto, na presença de inflamação, estes podem ser sensibilizados por prostaglandinas e dopamina, tendo como mediadores AMP cíclico e cálcio, tornando-os mais receptivos à ativação por bradicinina e histamina, substâncias endógenas indutoras de dor. Os estímulos, então, são conduzidos até o sistema nervoso central, onde em nivel talâmico e cortical, se faz a integração da sensação dolorosa. No cérebro há dois fenômenos antagônicos na modulação da dor, a ação dos neurotransmissores, anteriormente descrita e dos neuromoduladores, que a inibem (CHAPMAN 1986, WANNMACHER e FERREIRA 1995d).

Levando em conta a percepção subjetiva da dor, há indícios que o medo do tratamento odontológico (ansiedade) intensificaria a mesma, no entanto não há consenso na literatura. A ansiedade aumentaria a atividade simpática (produção de epinefrina), ativando os nociceptores, ou ao contrário, haveria a liberação de endorfinas (opióides endógenos), diminuindo a dor (KENT 1984, CHAPMAN 1986, 
A inflamação está presente em quase todas lesões produzidas no organismo humano. É uma resposta inespecífica de defesa do organismo a estímulos etiopatogênicos de natureza diversa, apresentando como manifestações clínicas - dor, hiperalgesia, eritema e edema. Na Odontologia está associada a traumatismos, infeç̧ões e depósitos antígeno-anticorpo (WANNMACHER e FERREIRA 1995c).

A nível histopatológico, nas primeiras 24 horas, ocorre vasodilatação arteriolar e venular, formação de edema e exsudato inflamatório na intimidade do tecido, e migração de polimorfonucleares e macrófagos. De 36 a 48 horas após, a migração leucocitária continua. Há sinais de regeneração e reconstrução de matriz conjuntiva (WANNMACHER e FERREIRA 1995c).

A nivel molecular, em conseqüência da ação dos fagócitos, há ruptura da membrana dos lisossomos, e liberação de enzimas (proteases, esterases, colagenases), ocasionando desnaturação protéica. Há, então, a ativação de uma série de sistemas que sintetizam e liberam substâncias intermediárias de lesão, como histamina, serotonina, bradicinina, prostaglandinas, leucotrienos e vários fatores quimiotáticos. Estas substâncias são responsáveis por vasodilatação, aumento da permeabilidade vascular, migração leucocitária, agregação plaquetária, além de outras manifestações do processo inflamatório agudo (WANNMACHER e FERREIRA 1995c).

Frente à agressão por microorganismos, o organismo apresenta respostas de defesa, que se expressam por resposta inflamatória aguda, destinada à destruição dos agentes invasores (fagocitose por macrófagos) ou à limitação do processo infeccioso (fibrina). Porém, nestes mecanismos, podem ocorrer também lesões das células do hospedeiro. Assim, endotoxinas, enzimas e componentes bacterianos podem estimular o sistema de complemento, o processo quimiotático e a imunidade celular, levando ao surgimento de algumas manifestações clínicas de infecção: reabsorção 
óssea, encistamento ou formação de granuloma, dor, febre e edema (WANNMACHER e FERREIRA 1995c).

\subsection{Grupos farmacológicos mais utilizados na Odontologia}

Os medicamentos mais utilizados, de uso sistêmico, são dos seguintes grupos terapêuticos: analgésicos, antiinflamatórios e antimicrobianos (YOHKOH 1984, CIANCIO e col. 1989, BATTELLINO e BENNUN 1993, CASTILHO e col. 1999).

\subsubsection{Analgésicos}

No tratamento terapêutico da dor, primeiramente deve-se identificar a origem da mesma, se é apenas sintomática ou se é proveniente de um processo infeccioso, neste caso, a dor será eliminada com o tratamento antimicrobiano apropriado, e o analgésico será apenas coadjuvante, podendo ser administrado no período que precede a remissão da infecção. O manejo sintomático está condicionado ao diagnóstico estabelecido, bem como ao comportamento do paciente frente à dor, o que origina diferentes respostas ao emprego de medidas medicamentosas ou não. A seqüência racional de emprego de analgésicos privilegia analgésicos não-opióides, associações de opióides e não-opióides e, finalmente, opióides (pouco utilizados na prática odontológica). Uma alternativa aos opióides, para tratamento de dores intensas consiste no uso de diclofenaco injetável ou naproxeno por via oral (WANNMACHER e FERREIRA 1995d).

Os analgésicos opióides afetam a percepção e reação aos impulsos que atingem o sistema nervoso central, não atuando no local da lesão ou sobre a condução nervosa. Os analgésicos não-opióides ou de ação periférica inibem diretamente os mediadores bioquímicos, que promovem a ativação das terminações nervosas livres nociceptivas no tecido afetado (COOPER e DESJARDINS 1991). 
Os analgésicos não-opióides que constam da lista de medicamentos da Secretaria Municipal de Saúde Pública de Campo Grande - MS (SESAU), são os seguintes: ácido acetilsalicílico (ácido salicílico), dipirona (pirazolona) e paracetamol (paraminofenol). Todos têm comprovada eficácia no tratamento de dores leves a moderadas, assim, na seleção de algum destes, deve-se levar em consideração os seguintes critérios: toxicidade relativa, efeitos adversos, diferenças farmacocinéticas que influenciam a comodidade de esquemas terapêuticos, experiência acumulada pelo profissional e respostas positivas previamente apresentadas pelo paciente (anamnese)(WANNMACHER e FERREIRA 1995e).

O ácido acetilsalicílico pode provocar efeitos adversos gastrointestinais, e também, afetar a agregação plaquetária. Em crianças e adolescentes, pode ocorrer a síndrome de Reye (encefalopatia e dano hepático grave), durante surtos de varicela ou quadros virais por influenza. Pode precipitar asma em adultos (WANNMACHER e FERREIRA 1995e).

O paracetamol geralmente é inócuo para os pacientes, no entanto, quando o uso é prolongado, mesmo em doses terapêuticas, leva a manifestações crônicas, como zumbidos, úlceras gástricas, comprometimentos renal e hepático (WANNMACHER e FERREIRA 1995e).

A dipirona teve o uso proibido nos Estados Unidos em 1977, devido à associação com a agranulocitose e aplasia medular, havendo a opção por produtos farmacêuticos alternativos e tratamentos não farmacológicos, com objetivo de diminuir o risco para o paciente (CHETLEY 1994). Segundo FUCHS (1988), por seus efeitos potenciais graves, só deve ser empregada quando há necessidade de uso parenteral. 
Em doses terapêuticas, a dipirona e o paracetamol mostram efeitos analgésicos e antitérmicos, mas não antiinflamatórios (WANNMACHER e FERREIRA 1995e). Os salicilatos apresentam as três propriedades, no entanto, para se obter efeitos antiinflamatórios, devem ser usadas grandes doses diárias (até $5 \mathrm{~g}$ ) durante longo período (COOPER e DESJARDINS 1991).

Há relatos na literatura que sugerem maior efeito analgésico da dipirona, em relação ao ácido acetilsalicílico e paracetamol, visto que seria capaz de bloquear diretamente a sensibilização dos receptores da dor, em vez da inibição da síntese de prostaglandinas nos tecidos inflamados, o que no entanto, não foi amplamente confirmado (LORENZETTI e FERREIRA 1985, MARQUEZ e FERREIRA 1987).

MAIA e VALENÇA (1994), estudaram os períodos pré e pós-cirúrgico de 69 pacientes submetidos a cirurgia odontológica seletiva, e não encontraram diferença estatisticamente significativa ao nível de $1 \%$ a $5 \%\left(\mathrm{p}>0,01\right.$ e $\left.\mathrm{p}>0,05-\chi^{2}=4,39\right)$, em relação ao alívio da dor (leve ou moderada), com a utilização dos seguintes medicamentos: Novalgina ${ }^{\circledR}$ (dipirona), Dôrico ${ }^{\circledR}$ (paracetamol) e AAS $^{\circledR}$ (ácido acetilsalicilico). Em relação à ausência ou presença de sangramento após a cirurgia para os diferentes medicamentos, também não houve diferença estatisticamente significativa ao nível de $1 \%$ a $5 \%\left(p>0,01\right.$ e $\left.p>0,05-\chi^{2}=7,18\right)$.

O alívio da dor é mais eficaz quando os analgésicos são dados precocemente, visto que o tratamento da dor já instalada é mais dificil, pois já foram desencadeados os mecanismos envolvidos na sensibilidade dolorosa. Recomenda-se o uso dos mesmos, nas situações em que a dor pós-operatória é esperada, de preferência antes que desapareça o efeito do anestésico local, indicando doses fixas ao invés da indicação "se necessário ou se sentir dor" (CIANCIO e col. 1989, WANNMACHER e FERREIRA 1995e). 
Em relação ao intervalo entre doses, a do ácido acetilsalicílico é de 4 horas, pois tem meia-vida aproximada de 2,5 horas, o que pode trazer certo incomodo na administração. A dipirona e o paracetamol podem ser administrados de 6 em 6 horas. A duração do tratamento deve ser tão breve quanto possível no manejo da dor, já que os efeitos adversos são proporcionais às doses e tempo de uso (WANNMACHER e FERREIRA 1995e).

\subsubsection{Antiinflamatórios}

Os antiinflamatórios só deverão ser utilizados quando as manifestações inflamatórias (dor, edema, trismo, limitação funcional) suplantarem o benefício da regeneração tecidual determinado pela reação inflamatória. Nas infecções, a reação inflamatória representa um mecanismo de defesa imunitária, não justificando o uso de antiinflamatórios, apenas a quimioterapia antimicrobiana específica. Nos casos de dor isolada ou preponderante sobre os outros sintomas, ou nos períodos de latência dos antibióticos, é recomendado o uso de analgésicos, para alívio temporário da dor e hipertemia (FERREIRA e WANNMACHER 1995a).

$\mathrm{Na}$ Odontologia são utilizados os antiinflamatórios esteróides e nãoesteróides. Os esteróides só deverão ser utilizados quando não houver resposta com o uso dos não-esteróides, ou quando for necessária uma ação inicial mais decisiva, por um período suficientemente curto (48 a 72 horas). A duração de tratamento consiste no tempo necessário para debelar o processo inflamatório (WANNMACHER e FERREIRA 1995f).

Os antiinflamatórios não-esteróides inibem a síntese de prostaglandinas, efetuada mediante a inativação da enzima cicloxigenase. Esse mecanismo de ação é, presumivelmente, responsável por alguns efeitos adversos, como a toxicidade renal e gastrintestinal (redução do efeito citoprotetor gástrico das prostaglandinas) 
(FERREIRA e WANNMACHER 1995a). O diclofenaco sódico é o medicamento disponível nas Unidades de Saúde da SESAU, para uso oral e injetável.

Os antiinflamatórios esteróides inibem a síntese de prostaglandinas, inibindo o edema, a vasodilatação e o efeito quimiotático dos leucócitos. Em altas concentrações teciduais, diminuem a fagocitose e digestão de antígenos. Como moduladores da reação imunitária, alteram, predominantemente, subpopulações de linfócitos (WANNMACHER 1995b).

No uso prolongado do esteróide, sistêmico ou tópico, podem ocorrer efeitos adversos. Nos tratamentos sistêmicos crônicos, mais do que 7 dias, os efeitos indesejados aparecem na vigência das doses farmacológicas ou na suspensão destas (supressão do eixo hipotálamo-hipófise-adrenal). Podem ocorrer efeitos metabólicos, endócrinos e outros, tais como a predisposição a infecções. Os tratamentos agudos (habituais na Odontologia) não apresentam efeitos adversos e podem ser suspensos abruptamente (TRUMMEL 1991, WANNMACHER 1995b).

Nas Unidades de Saúde da SESAU, encontra-se os três tipos de corticóides, segundo duração do efeito: curta (< 12 horas), hidrocortisona (injetável); intermediária (18-36 horas), prednisona (oral); e longa (36-54 horas), dexametasona (uso oral, tópico e injetável).

\subsubsection{Antimicrobianos}

Para tratamento das infecções, são usados antimicrobianos, direcionados à erradicação dos microorganismos. Não se trata de medidas sintomáticas, embora os sinais e sintomas desapareçam com o extermínio das bactérias, visto que cessa a produção de componentes bacterianos, geradores de reação inflamatória. Assim sendo, os analgésicos e antiinflamatórios, são secundários e coadjuvantes, sendo 
eventualmente ministrados no período de latência do antimicrobiano (MENDES 1995).

Os antimicrobianos devem ser tóxicos, ou preferencialmente letais, para os microorganismos invasores, mas sem possuir efeito sobre as células do hospedeiro, isto é, deve ter toxicidade seletiva, que é determinada pelo mecanismo de ação dos mesmos, como inibidores da sintese da parede celular, protéica ou do ácido nucleico (MONTGOMERY 1991a).

Quando há inibição da síntese da parede celular, consegue-se toxicidade seletiva máxima, visto que as células dos mamíferos não possuem paredes celulares, no entanto, tais fármacos só são eficazes, durante a fase do ciclo celular bacteriano, no qual as bactérias estão crescendo (produção de novo material da parede celular). A penicilina e a cefalosporina são alguns exemplos deste grupo. Assim sendo, este tipo de antibiótico (bactericida) não pode ser prescrito em associação com outros que inibem o crescimento bacteriano (bacteriostático), senão haverá perda do efeito bactericida (MONTGOMERY 1991a).

Dentre os antibióticos bactericidas, os de interesse para a Odontologia são os seguintes: penicilinas, cefalosporinas, metronidazol. Dentre os bacteriostáticos, podese citar: eritromicina, clindamicina, tetraciclina etc.. Vale ressaltar que estas designações não são absolutas, visto que concentrações subletais de fármacos bactericidas podem inibir a multiplicação bacteriana e altas concentrações de alguns fármacos bacteriostáticos podem matar microorganismos sensíveis (MONTGOMERY 1991a).

$\mathrm{Na}$ inibição da síntese protéica, o crescimento e sobrevida celular bacteriana são inibidos pela ausência de proteínas. Há portanto, menor grau de toxicidade seletiva, visto que ocorre o bloqueio de uma reação vital tanto para o hospedeiro 
quanto para o microorganismo. Neste grupo tem-se o cloranfenicol, eritromicina, lincomicina e clindamicina (MONTGOMERY 1991a).

A rifampicina e o metronidazol são opções dentre os fármacos inibidores de ácido ribonucléico (RNA), através da ligação à RNA-polimerase dependente do DNA nos microorganismos, mas não nas células humanas (MONTGOMERY 1991a).

Um passo importante para o sucesso da antibioticoterapia, é o diagnóstico correto do microorganismo ( ou microorganismos) infectantes e a escolha do fármaco mais específico e eficaz (FERREIRA e WANNMACHER 1995b). As infecções dentárias, geralmente são causadas por microorganismos aeróbios Gram-positivos e anaeróbios Gram-positivos e Gram-negativos (MONTGOMERY 1991a). Quando o antibiótico é ativo contra a maioria das bactérias Gram-positivas e Gram-negativas, é chamado de "largo espectro" e se atua em um número restrito de microorganismos é de "pequeno espectro". Já que a eficácia se relaciona com a especificidade, é sempre preferivel escolher um antibiótico de pequeno espectro (MENDES 1995).

$\mathrm{Na}$ prática odontológica, os antimicrobianos são usados principalmente para: tratamento de infecção dentária aguda, profilaxia em pacientes em risco de desenvolver problemas em conseqüência da bacteremia causada por procedimentos odontológicos (com sangramento) ou lesão traumática (por exemplo, endocardite bacteriana), e profilaxia em pacientes com comprometimento nos mecanismos de defesa (causados por certas doenças ou tratamento farmacológico) (MONTGOMERY 1991a).

A cobertura antibiótica deve durar, no mínimo, 48 horas após a remissão completa dos sintomas clínicos, assim sendo, a duração do tratamento varia com o tipo de infecção, o estado dos mecanismos de defesa do paciente e vários outros fatores. Geralmente, o tratamento das infecções habituais da boca, de origem 
bacteriana, requer uma média de 5 a 7 dias de antibioticoterapia (MONTGOMERY 1991a).

Levando em conta os antibióticos disponíveis nas Unidades de Saúde da SESAU, e as recomendações na literatura para a utilização na Odontologia, a penicilina é o antibiótico de primeira escolha. As outras opções são: eritromicina e cefalosporina (cefalexina). A eritromicina é a opção para pacientes alérgicos à penicilina. A tetraciclina pode ser utilizada em certos tipos de doença periodontal. $O$ metronidazol é usado em associação com outro antibiótico, atuando como agente anaerobicida (MONTGOMERY 1991b, MENDES 1995)

No grupo das penicilinas, há a disponibilidade na SESAU, dos seguintes medicamentos: ampicilina, penicilina $G$ benzatina e penicilina $G$ procaína. Agem na sintese da parede celular bacteriana. A ampicilina é de amplo espectro, e as demais são de pequeno espectro. Os efeitos adversos mais freqüentes são as reações alérgicas, principalmente no uso parenteral; da ampicilina tem-se os seguintes: rash cutâneo e diarréia (MONTGOMERY 1991b, MENDES 1995).

A penicilina $\mathrm{G}$ procaína apresenta maior eficácia microbiológica, porém o inconveniente da administração parenteral, sendo que o mesmo espectro com administração por via oral, é encontrado na penicilina $\mathrm{V}$, não disponível na SESAU. A penicilina $G$ benzatina não deve ser usada no tratamento ou na profilaxia de infecções odontológicas, em função do seu baixo nivel sérico $(0,10-0,15 \mathrm{UL} / \mathrm{ml})$ (MONTGOMERY 1991b, MENDES 1995).

Em relação aos testes de sensibilidade à penicilina, há consenso na literatura que possuem valor limitado. A não-reatividade da prova não é conclusiva, visto que podem ocorrer reações tardias. Além disso, o paciente corre o risco de sofrer choque anafilático com o próprio teste. A melhor conduta antes de aplicar a droga, é a de 
perguntar ao paciente se já utilizou penicilina ou outro antibiótico, e se teve alguma reação (urticária, edema dos lábios, das pálpebras ou da língua, prurido, dificuldade respiratória). No caso da resposta ser positiva, não aplicar o antibiótico (SILVA 1996).

A ampicilina é utilizada principalmente no tratamento de infecções por Gramnegativos ou infecções mistas por Gram-positivos e Gram-negativos, sendo menos ativa contra Gram-positivos (predominantes nas infecções odontológicas). Não deve ser utilizada, portanto, como substituto das penicilinas $\mathrm{G}$ ou $\mathrm{V}$, de pequeno espectro (mais especificidade, maior eficácia). A penicilina $\mathrm{V}$ é de primeira escolha para a Odontologia, visto que a absorção da penicilina $G$ por via oral é deficiente (MONTGOMERY 1991b, MENDES 1995).

A eritromicina tem espectro antimicrobiano similar ao da penicilina $G$, no entanto, o mecanismo de ação não é o mesmo. É bacteriostático, embora em altas concentrações, possam agir como bactericida. Atua inibindo a síntese protéica. Pode causar manifestações digestivas (MENDES 1995).

As cefalosporinas são bactericidas e apresentam o mesmo mecanismo de ação das penicilinas, isto é, inibição da síntese da parede bacteriana. Classificam-se em várias gerações, conforme as modificações nas cadeias laterais da estrutura básica, no entanto, a cefalexina (primeira geração) é o grupo mais ativo contra cocos Grampositivos. Apresentam baixa toxicidade. As reações alérgicas são similares às das penicilinas, porém com menor incidência ( $5 \%$ dos casos). A hipersensibilidade cruzada com alérgicos à penicilina, ocorre em $1 \%$ dos pacientes. Pode causar distúrbios digestivos (MENDES 1995).

O metronidazol não deve ser utilizado como agente único em infeções odontogênicas, exceto em certas doenças periodontais (gengivite ulcerativa 
necrosante aguda e periodontite avançada), pois é altamente ativo para germes anaeróbios, especialmente bacilos Gram-negativos. Em geral, é bem tolerado, podendo ocorrer: sintomas gastrointestinais leves, gosto metálico na boca, neuropatia periférica, boca seca, estomatite, glossite e neutropenia reversível (MENDES 1995).

\subsection{Interações medicamentosas}

Quando dois ou mais fármacos são prescritos simultaneamente ou seqüencialmente, pode ocorrer o seguinte: indiferentismo farmacológico, quando há independência de ação dos fármacos associados; ou interação farmacológica, quando uma das drogas interfere de algum modo sobre as outras, alterando o efeito esperado (WANNMACHER e FERREIRA 1995b).

As interações podem ser benéficas, portanto, terapeuticamente aproveitáveis, quando se deseja aumentar a eficácia ou corrigir algum defeito indesejável sem comprometer a resposta terapêutica; ou nocivas, quando diminuem a eficácia de uma ou mais drogas, ou produzem efeitos adversos, constituindo-se em risco para o paciente (WANNMACHER e FERREIRA 1995b).

De acordo com Sloan (1986) citado por PAUNOVICH e col. (1997, p.702), quando duas drogas são prescritas, o potencial de interação é de $6 \%$; com cinco drogas, passa para $50 \%$; e com oito ou mais drogas, é de $100 \%$.

Alguns pacientes são mais propensos a evidenciar interações adversas, como os idosos (pelo uso de muitos fármacos), os insuficientes renais, hepáticos, cardíacos e respiratórios, os com hipotireoidismo, epilepsia grave, asma aguda e diabete descompensado (WANNMACHER e FERREIRA 1995b). 


\section{Quadro 1}

Algumas interações farmacológicas nocivas de interesse para a Odontologia e os efeitos adversos.

\begin{tabular}{|c|c|}
\hline Interações medicamentosas & Efeitos adversos \\
\hline antibiótico bacteriostático + antibiótico bactericida & $\begin{array}{l}\text { diminuição do efeito dn } \\
\text { antibiótico bactericida }\end{array}$ \\
\hline $\begin{array}{l}\text { prescrição de dois ou mais medicamentos } \\
\text { relacionados à irritação gástrica (paracetamol, } \\
\text { cetoconazol, aminofilina, metronidazol, } \\
\text { diclofenaco, ácido acetilsalicílico, prednisona, } \\
\text { eritromicina, amoxicilina, dexametasona etc.) }\end{array}$ & irritação gástrica \\
\hline metronidazol + fenobarbital & perda do efeito do metronidazol \\
\hline $\begin{array}{l}\text { anticoncepcional + antibiótico (ampicilina, } \\
\text { penicilina } \mathrm{V} \text {, tetraciclina) }\end{array}$ & $\begin{array}{llll}\text { perda do efeito do } \\
\text { anticoncepcional }\end{array}$ \\
\hline penicilina + ácido acetilsalicílico & $\begin{array}{l}\text { aumento da toxicidade do ácido } \\
\text { acetilsalicílico }\end{array}$ \\
\hline hidróxido de alumínio + ácido acetilsalicílico & $\begin{array}{l}\text { reduz a concentração plasmática } \\
\text { do salicilato }\end{array}$ \\
\hline tetraciclina + ácido acetilsalicílico & $\begin{array}{l}\text { o ácido acetilsalicílico diminui a } \\
\text { absorção oral das tetraciclinas }\end{array}$ \\
\hline fenobarbital + penicilina & $\begin{array}{l}\text { perda do efeito antimicrobiano , } \\
\text { podendo levar à continuidade da } \\
\text { infecção }\end{array}$ \\
\hline fenobarbital + tetraciclina & $\begin{array}{l}\text { perda do efeito antimicrobiano, } \\
\text { podendo levar à continuidade da } \\
\text { infecção }\end{array}$ \\
\hline antiinflamatórios não esteróides + anti-hipertensivo & \begin{tabular}{|llcc} 
redução da & síntese & de \\
prostaglandina & ou & retenção & de \\
sódio & & & \\
\end{tabular} \\
\hline $\begin{array}{l}\text { ácido acetilsalicílico + anticoagulante / } \\
\text { antiplaquetários }\end{array}$ & alteração da coagulação sangüínea \\
\hline ácido acetilsalicílico + corticosteróide & $\begin{array}{l}\text { redução da concentração e efeito } \\
\text { dos salicilatos }\end{array}$ \\
\hline corticosteróide + diurético & 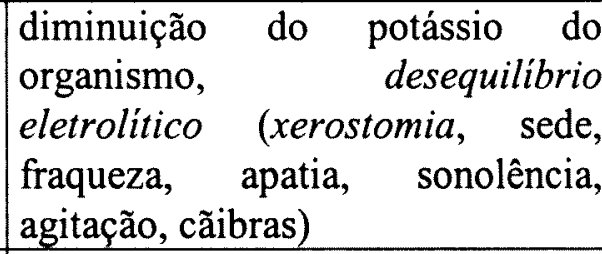 \\
\hline corticosteróide + antibiótico & pode ocorrer superinfecções \\
\hline
\end{tabular}

Fontes: WANNMACHER e FERREIRA 1995b, WYNN 1997, SECRETARIA MUNICIPAL DE SAÚDE DE VITÓRIA 1998, ARMONIA e TORTAMANO 1998. 


\subsection{Pacientes especiais}

Pacientes especiais são todos aqueles que requerem cuidados extras, devido à presença de doenças sistêmicas, ou condições fisiológicas / anatômicas específicas, tais como: gravidez e amamentação. Estão incluídos também, a criança e o idoso (LORO 1986, NEDER 1995, ARMONIA e TORTAMANO 1998).

Estes pacientes apresentam alterações nas condições orgânicas, influenciando eventos associados à prática odontológica, como ansiedade, dor, sangramento etc., além disto, habitualmente utilizam medicamentos que podem causar alguma alteração na cavidade bucal (xerostomia, por exemplo), ou mesmo interagir com aqueles de emprego odontológico, determinando efeitos adversos. O cirurgiãodentista só saberá se o paciente tem ou não uma condição especial, se realizar a anamnese ou se receber um laudo do médico do paciente (FERREIRA e WANNMACHER 1995d, MILLER e col. 1997).

A anamnese, segundo padrão mínimo da Associação Dental Americana, deve conter os seguintes itens, que deverão ser atualizados a cada visita: nome e número do telefone do paciente; data do último atendimento médico e odontológico; avaliação da saúde geral e aparência do paciente (impressão do cirurgião-dentista); lista de doenças sistêmicas (principalmente alterações cardíacas); medicamentos que o paciente faz uso; tratamentos que estão em andamento (se há ou não história de radioterapia ou quimioterapia); presença de desordens sangüíneas, alergias a drogas, consumo de álcool ou cigarro e reações adversas a anestésicos; pressão sangüínea e pulso; gravidez ou outra condição física; tolerância física e emocional frente aos procedimentos odontológicos (LAWNEY 1995).

A gestação compreende situação única, na qual a exposição a determinada droga envolve dois organismos, sendo que em ambos, os efeitos adversos de 
fármacos diferem muito dos que ocorrem em mulheres não-grávidas. A resposta fetal, diante da medicação, é diferente da observada na mãe, podendo resultar em toxicidade fetal, com lesões de variada natureza, algumas irreversíveis. O primeiro trimestre da gestação é o período de desenvolvimento fetal mais sujeito à teratogenia (GOMES e col. 1999, WANNMACHER e FERREIRA 1995d).

É dificil determinar os efeitos dos medicamentos sobre o feto, visto que há impossibilidades éticas envolvidas na pesquisa em humanos. As informações disponíveis são oriundas de observação clínica de casos em que se associem os fatores causa-efeito, e nem sempre podem ser generalizadas, devido às diferentes respostas individuais nas populações. Nos casos de necessidade de prescrição de medicamentos na gravidez, deve haver sempre a opção por medicamentos cujos benefícios à mãe e ao feto sejam maiores que os riscos causados aos dois (GOMES e col. 1999).

Na lactação, deve-se ter o cuidado de usar fármacos que não prejudiquem o lactente, visto que a excreção dos mesmos pode ser prejudicada pela imaturidade dos órgãos de eliminação do recém-nascido. São poucos os fármacos comprovadamente proibidos nesta situação (vide Quadro 2), de qualquer modo, deve-se recomendar o uso das menores doses cabíveis, um maior espaçamento entre as doses, a menor duração de tratamento possível e a ingestão dos medicamentos logo após o término de uma mamada, pois assim o pico sérico materno ocorrerá num período em que a criança não está sendo amamentada (WANNMACHER e FERREIRA 1995g, ABREU e col. 1996).

Segundo DOERING e KERBER (1993), embora pareça racional a ingestão de medicamentos logo após o término de uma mamada, este procedimento pode ter um efeito contrário, pois a presença de um fármaco no leite materno, na maioria das 
vezes, é um efeito tardio à administração. Há a necessidade de difundir informações sobre os riscos da utilização de medicamentos durante a lactação, e a realização de estudos farmacocinéticos e de farmacovigilância, principalmente dos fármacos mais utilizados, pois não existem estudos suficientes (COSTA e CASTRO 1999).

A criança não é um adulto de pequenas dimensões. A simples correção da dose de um medicamento, em relação ao peso, não garante a obtenção de concentrações plasmáticas médias para o estado de equilíbrio, quando se compara com o adulto, visto que, são complexas as alterações fisiológicas relacionadas à sua maturação. Estas alterações vão afetar todas as etapas da transformação dos medicamentos no organismo (absorção, distribuição, metabolismo e excreção), sendo necessárias adaptações posológicas (SANZ e col. 1989, NUNES 1997).

Um exemplo de diversidade da resposta da criança, é a coloração marrom permanente e hipoplasias dentárias, causada pelo uso da tetraciclina, quando este medicamento é ingerido durante a fase de formação das coroas dentárias. A remoção das manchas é bastante difícil, mesmo utilizando técnicas de clareamento dental. Diante disto, a conduta correta é não utilizar este fármaco, até os 8-9 anos de idade (PITREZ 1995, DUNN 1998).

O envelhecimento das populações é observado em todo o mundo. Há maior número de idosos, e ainda com os dentes presentes, pela menor incidência de cárie dental, devido aos avanços da odontologia preventiva. Isto significa que maior número de idosos estará buscando algum tipo de tratamento odontológico, no qual haverá ou não a necessidade da prescrição de medicamentos (NEIDLE e PICOZZI 1991).

O idoso sofre mais doenças que os jovens, também usa mais medicamentos, prescritos ou não. Além disto, o envelhecimento fisiológico e cronológico 
freqüentemente evolui em velocidades diferentes, $\mathrm{e}$ isto torna a população idosa mais heterogênea que, por exemplo, uma população de crianças entre o nascimento e a puberdade, resultando em respostas diferentes do organismo às drogas (NEIDLE e PICOZZI 1991, SPENCER 1997).

Na insuficiência renal, há um decréscimo na filtração glomerular, bem como das funções de absorção e secreção do rim. Como a maioria das drogas são eliminadas do organismo através dos rins, na presença de disordens no sistema renal, há alteraçð̃es significantes no metabolismo das drogas (NAYLOR e FREDERICKS 1996).

No tratamento odontológico do cardiopata, devem ser tomadas medidas extras, com os seguintes pacientes: portadores de valvulopatias ou cardiopatias congênitas, nos quais realiza-se a profilaxia antibiótica, visando à prevenção da endocardite infecciosa; portadores de prótese valvular metálica ou aqueles com história pregressa de embolia pulmonar ou acidente vascular cerebral isquêmico, que rotineiramente utilizam anticoagulante, e portanto correm o risco de hemorragias após intervenção cirúrgica; e os coronariopatas hipertensos submetidos a intervenção odontológica, nos quais o estresse pode provocar parada cárdiorespiratória, devendo os mesmos serem compensados por medicamentos específicos (MURRAH e col. 1987, AMARAL e col. 1994).

A seguir, nos Quadros 2 e 3, são enfocadas algumas doenças e condições específicas, para as quais são necessárias algumas precauções na prática odontológica usual. 
Quadro 2

Pacientes com condições fisiológicas / anatômicas específicas e precauções a serem tomadas, quando houver necessidade de prescrições odontológicas de medicamentos de uso sistêmico.

\begin{tabular}{|c|c|}
\hline Pacientes & Precauções \\
\hline \multirow[t]{5}{*}{ Grávidas } & não utilizar benzodiazepínicos, visto que pode haver o aparecimento de fenda labial ou palatina \\
\hline & os antiinflamatórios não esteróides podem causar hipertensão pulmonar no feto \\
\hline & a tetraciclina causa descoloração permanente dos dentes da criança \\
\hline & o estolato de eritromicina pode causar alterações hepáticas no feto \\
\hline & o ácido acetilsalicílico pode prolongar o trabalho de parto e sangramento na mãe \\
\hline \multirow[t]{2}{*}{ Lactantes } & o metronidazol causa vômitos, anorexia e citopenia na criança \\
\hline & a tetraciclina causa coloração anormal permanente nos dentes da criança \\
\hline \multirow[t]{4}{*}{ Crianças } & $\begin{array}{l}\text { são contra-indicados os antiinflamatórios não esteróides (ex., piroxicam, diclofenaco), visto que não } \\
\text { foram aprovados para uso infantil nos Estados Unidos }\end{array}$ \\
\hline & evitar a dipirona, devido a agranulocitose \\
\hline & $\begin{array}{l}\text { pode ocorrer Síndrome de Reye, quando o ácido acetilsalicílico é prescrito na presença de doenças } \\
\text { virais, principalmente gripe ou varíola }\end{array}$ \\
\hline & $\begin{array}{l}\text { a tetraciclina até os 8-9 anos de idade, visto que pode causar descoloração dos dentes e hipoplasia no } \\
\text { esmalte dentário, de forma permanente }\end{array}$ \\
\hline \multirow[t]{5}{*}{ Idosos } & $\begin{array}{l}\text { cuidado com as reações adversas e interações medicamentosas, visto que o idoso geralmente usa mais } \\
\text { drogas, prescritas ou não }\end{array}$ \\
\hline & $\begin{array}{l}\text { os idosos são mais sensiveis que os adultos jovens aos efeitos depressores das drogas sobre o sistema } \\
\text { nervoso central, podendo ser necessária a redução de doses de analgésicos e ansiolíticos }\end{array}$ \\
\hline & $\begin{array}{l}\text { devido à perda na competência homeostática, as drogas que alteram a pressão arterial, freqüência } \\
\text { cardiaca e tônus do músculo liso, devem ser utilizadas com cuidado }\end{array}$ \\
\hline & $\begin{array}{l}\text { para a prevenção e tratamento das infecções, pode ser necessária uma antibioticoterapia mais agressiva, } \\
\text { devido à senilidade imunológica }\end{array}$ \\
\hline & monitorar o uso de drogas eliminadas principalmente pelo rim, pois pode estar diminuída a função renal \\
\hline
\end{tabular}




\section{Quadro 3}

Pacientes com doenças sistêmicas e precauções a serem tomadas, quando houver necessidade de prescrições odontológicas de medicamentos de uso sistêmico.

\begin{tabular}{|c|c|}
\hline Pacientes & Precauções \\
\hline Com doença neuropsicológica & $\begin{array}{l}\text { cautela com a prescrição de analgésicos opióides e ansiolíticos benzodiazepínicos, em função da interação entre } \\
\text { depressores do sistema nervoso central }\end{array}$ \\
\hline \multirow[t]{2}{*}{ Com doença cardiovascular } & $\begin{array}{l}\text { nos pacientes tratados com diuréticos, bloqueadores alfa-adrenérgicos e inibidores da convertase, o efeito } \\
\text { hipertensivo é prejudicado pelo uso de antiinflamatórios não-esteróides e esteróides }\end{array}$ \\
\hline & $\begin{array}{l}\text { pacientes portadores de patologias cardíacas de risco para desenvolver endocardite bacteriana, necessitam de } \\
\text { profilaxia antimicrobiana ante procedimentos cruentos }\end{array}$ \\
\hline Com doença respiratória & adultos com asma brônquica podem ter a doença precipitada por aspirina e os demais antiinflamatórios não-esteróides \\
\hline \multirow[t]{2}{*}{ Com doença digestiva } & $\begin{array}{l}\text { em presença de doença ulcerosa péptica, os analgésicos não-opióides e os antiinflamatórios não esteróides estão } \\
\text { contra-indicados por seus efeitos inibidores da proteção gástrica }\end{array}$ \\
\hline & $\begin{array}{l}\text { o uso de antiácidos e antagonistas } \mathrm{H} 2 \text { diminuem a absorção de outros fármacos administrados concomitantemente } \\
\text { (em relação às tetraciclinas, a atividade antimicrobiana se anula) }\end{array}$ \\
\hline Com doença endócrina & o uso de antiinflamatórios esteróides e não-esteróides aumenta a glicemia \\
\hline Com doença renal & fármacos indutores de nefrotoxicidade são contra-indicados (ex., tetraciclina ) \\
\hline Com doença hematológica & $\begin{array}{l}\text { pacientes anticoagulados ou com discrasias sangüíneas não devem receber analgésicos não-opióides ou } \\
\text { antiinflamatórios não-esteróides (tipo aspirina) que interferem com a agregação plaquetária pelo risco de aumentar a } \\
\text { tendência hemorrágica }\end{array}$ \\
\hline \multirow[t]{2}{*}{ Epiléticos } & $\begin{array}{l}\text { os anticonvulsionantes, em geral, são depressores do sistema nervoso central (SNC), portanto, deve-se evitar associar } \\
\text { drogas estimulantes ou depressoras do SNC }\end{array}$ \\
\hline & $\begin{array}{l}\text { os anticonvulsionantes mais utilizados são estimulantes potentes das enzimas hepáticas responsáveis pela degradação } \\
\text { de outros medicamentos (ex., tetraciclinas) }\end{array}$ \\
\hline Hipertensos & evitar antiinflamatórios (ácido acetilsalicílico e diclofenaco) e corticosteróides. \\
\hline Imunodeprimidos & necessitam do uso profilático de antibióticos \\
\hline Trombose & evitar uso de hemostáticos. \\
\hline
\end{tabular}

Fontes: SECRETARIA MUNICIPAL DE SAÚDE DE VITÓRIA, 1998; ARMONIA e TORTAMANO, 1998; WANNMACHER e FERREIRA, 1995. 


\subsection{Considerações finais}

Segundo WANNMACHER (1995a), a prescrição medicamentosa apesar de não ser utilizada em todos pacientes odontológicos, é uma necessidade da prática clínica, no entanto, não tem sido uma preocupação cotidiana dos cirurgiões-dentistas. Estes profissionais devem constituir o próprio armamentário terapêutico, levando em conta o real papel dos medicamentos no processo de cura e alívio de sintomas, e os preceitos que regem a correta seleção, administração e controle dos fármacos empregados, precavendo-se da influência das propagandas mercadológicas, nem sempre concernentes com princípios científicos e éticos.

A Organização Mundial da Saúde tem se preocupado, de maneira crescente, com o consumo de medicamentos, sendo que os estudos desta natureza, são de suma importância para detectar possíveis problemas nos serviços de saúde, na medida que fatos relevantes destacam a amplitude das interferências sociais, econômicas e epidemiológicas na utilização de medicamentos (ORGANIZAÇÃO MUNDIAL DA SAÚDE 1993a, NEUTEL 1998).

Segundo CASTILHO e col. (1999), na Odontologia, a inserção do medicamento na prática clínica, tem sido pouco analisada. Um dos motivos da pequena produção científica existente, talvez seja devido ao consenso geral de que o dentista prescreve pouco, em comparação aos médicos (por exemplo); o arsenal de drogas é restrito; e a utilização de tratamentos não-medicamentosos (intervenções clínicas locais) é freqüente.

Algumas características da prescrição de medicamentos de cirurgiõesdentistas da Rede Municipal de Saúde de Campo Grande, foram estudadas por PINTO (1998), através de questionário aplicado a 53 profissionais e pela análise de 543 receitas odontológicas, tendo sido observado o seguinte: há um certo 
desconhecimento em relação à lista de medicamentos disponíveis nas Unidades de Saúde e deficiências em relação às prescrições odontológicas, que apresentaram posologia $(56 \%)$ e preenchimento $(60,2 \%)$ incorretos. Diante destes resultados, e sabendo que no campo da Odontologia, são escassas as pesquisas sobre uso de medicamentos no serviço público, considerou-se relevante o presente estudo. 


\section{OBJETIVOS}

\subsection{Objetivo Geral}

Conhecer alguns aspectos da prescrição odontológica e o uso de medicamentos no serviço público, dos Cirurgiões-Dentistas que atuam nas Unidades de Saúde de Campo Grande - MS.

\subsection{Objetivos Específicos}

2.2.1 Conhecer algumas peculiaridades do perfil de capacitação dos CirurgiõesDentistas que atuam nas Unidades de Saúde de Campo Grande - MS, em relação ao uso de medicamentos no serviço público e a prescrição odontológica.

2.2.2 Identificar fatores predominantes que interferem nas prescrições dos Cirurgiões-Dentistas que atuam nas Unidades de Saúde de Campo Grande - MS.

2.2.3 Observar se os Cirurgiões-Dentistas que atuam nas Unidades de Saúde de Campo Grande - MS, preocupam-se com o uso racional de medicamentos.

2.2.4 Propor medidas que visem o uso racional de medicamentos, no atendimento odontológico das Unidades de Saúde. 


\section{MÉTODO}

\subsection{Tipo de Pesquisa}

É um levantamento de alguns aspectos do padrão de prescrição dos cirurgiões-dentistas que atuam no serviço público, sendo portanto, um survey analítico.

\subsubsection{Instituição onde efetuou-se a pesquisa}

Secretaria Municipal de Saúde Pública de Campo Grande-MS (SESAU). A pesquisa foi devidamente autorizada pelo responsável da instituição e aprovada pelo Comitê de Ética da Faculdade de Saúde Pública da Universidade de São Paulo (FSP/USP).

\subsection{Coleta de dados}

O trabalho de campo constou das seguintes atividades:

- questionário dirigido aos cirurgiões-dentistas;

- análise de prescrições odontológicas e questionários dirigidos a pacientes, no momento da dispensação dos medicamentos e

- análise dos prontuários de pacientes identificados nas prescrições odontológicas analisadas.

\subsubsection{Questionário dirigido aos cirurgiões-dentistas}

Para a obtenção de informações dos cirurgiões-dentistas sobre prescrição e uso de medicamentos no serviço público, foi empregado um questionário (ver Anexo 1), previamente testado (PINTO 1998), com 14 questões objetivas, sendo a última subdividida em quatro partes, pois é uma simulação de três casos clínicos, com as alternativas de possiveis prescrições medicamentosas e uma questão sobre 
contra-indicação de medicamentos. Esta última questão tem por objetivo, checar o conhecimento farmacológico do profissional em relação ao tratamento de enfermidades bucais especificas, visto que no serviço odontológico isto não seria possível, pois não há dados disponíveis quanto ao diagnóstico da enfermidade que gerou determinada prescrição medicamentosa. As respostas consideradas corretas estão assinaladas no questionário disponível no Anexo 1 .

As quatro perguntas iniciais abordam dados relacionados à formação profissional e ao tempo de inserção no serviço. As outras contemplam alguns objetivos desta pesquisa, em relação a: utilização de livros ou similares para prescrever medicamentos, cursos e palestras afins, se o profissional conhece ou não a lista dos medicamentos disponíveis nas Unidades de Saúde e situações relacionadas ao ato de prescrever.

$\mathrm{Na}$ distribuição dos questionários a todos os cirurgiões-dentistas lotados em Unidades de Saúde de Campo Grande-MS, foram excluídos: 3 cirurgiões-dentistas lotados no nível central e 8 coordenadores odontológicos, 2 de cada distrito sanitário (Leste, Norte, Oeste e Sul), por realizarem atividades de coordenação e supervisão; 8 profissionais que atuam em áreas rurais e 3 cirurgiões-dentistas cedidos para outras instituições, por efetuarem atendimentos odontológicos distintos e diferenciados, restaram então 188 profissionais, que receberam os questionários.

Os questionários (contendo: nota explicativa inicial, com dados da pesquisa e envelope com lacre) foram deixados no início do turno de trabalho dos profissionais, e recolhidos no dia seguinte. Para garantir o anonimato, os envelopes foram abertos somente após o encerramento da coleta dos dados. 


\subsubsection{Análise de prescrições odontológicas e questionário dirigido aos pacientes}

Foi realizada para avaliar a qualidade das prescrições odontológicas, a fim de detectar possiveis falhas de preenchimento e na posologia. A amostra constituiu de prescrições efetuadas pelos cirurgiões-dentistas durante o mês de agosto de 2000, em Unidades de Saúde pré-selecionadas (Quadro 4).

As prescrições odontológicas ocorrem principalmente para o tratamento de infecções ou em períodos pré e/ou pós-cirúrgicos, sendo portanto pouco influenciadas, qualitativamente, por aspectos geográficos, infra-estrutura das Unidades de Saúde ou tipo de atendimento (ambulatorial ou plantão).

\section{Quadro 4}

Unidades de Saúde selecionadas para análise das prescrições, segundo Distrito Sanitário da Secretaria Municipal de Saúde, Campo Grande - MS, 2000.

\begin{tabular}{|l|c|}
\hline Distrito & Unidades de Saúde \\
\hline Oeste & Vila Almeida \\
\hline Norte & $\begin{array}{c}\text { Coronel Antonino } \\
\text { Nova Bahia }\end{array}$ \\
\hline Leste & $\begin{array}{c}\text { Tiradentes } \\
\text { Moreninha }\end{array}$ \\
\hline Sul & Guanandy \\
\hline
\end{tabular}

Na seleção das Unidades de Saúde foram observados os seguintes aspectos:

- possuem farmácia, com horário de funcionamento até às 24:00 horas, e além disto, oferecem atendimento odontológico 24 horas- atendimento ambulatorial (de Segunda a Sexta-feira, em horário comercial), plantão odontológico noturno (todos os dias) e plantão odontológico diurno (aos finais de semana) - o que proporciona 
maior volume de prescrições odontológicas, devido ao número expressivo de pacientes que são atendidos;

- foram excluídas as Unidades de Saúde que não fazem a dispensação de medicamentos, que são as Unidades Escolares e Unidades Conveniadas, e também, as Unidades de Saúde com atendimento estritamente ambulatorial, que apesar de efetuarem a dispensação de medicamentos, não possuem um volume de prescrições odontológicas que justificasse, em relação às interferências na rotina de trabalho, a inclusão nesta etapa da coleta de dados, restando portanto as Unidades de Saúde citadas no Quadro 4;

- a exclusão das Unidades citadas anteriormente, não afetaram qualitativamente a amostra, visto que os profissionais que atuam nos plantões (mais ou menos $60 \%$ do cirurgiões-dentistas lotados na SESAU) também fazem atendimento ambulatorial, estando lotados nos diversos tipos de Unidades de Saúde. A escala de plantão é feita independentemente da lotação ambulatorial do cirurgião-dentista, podendo um profissional de um distrito fazer plantão em outro distrito. Além disso, a escala de plantão é mensal, de modo que todos os cirurgiões-dentistas plantonistas atuam no período de 1 mês, o que justifica a escolha deste tempo para a análise das prescrições.

Para esta etapa da coleta de dados, foi necessário o treinamento dos farmacêuticos responsáveis pelas farmácias e dos farmacêuticos plantonistas das referidas unidades, após concordância da chefia destes profissionais. As instruções metodológicas, e também demais informações pertinentes sobre a proposta da pesquisa, foram repassadas em reunião com a pesquisadora.

Alguns dias antes do início da coleta, os farmacêuticos responsáveis foram visitados nas próprias farmácias nas Unidades de Saúde, tendo sido reafirmada a 
colaboração destes. Efetuou-se a entrega do material necessário (impresso numerado do questionário a ser entregue para o paciente (Anexo 2), prancheta com caneta acoplada, caixa para acondicionar as prescrições odontológicas e grampeador. Junto à janela que ocorre a dispensação, em local visível para o profissional, foi fixado um cartaz com um lembrete quanto ao período de coleta de dados e de forma bem sucinta, as instruções metodológicas.

O farmacêutico responsável pela farmácia, ou plantonista, separou as prescrições odontológicas ( $2^{\mathrm{a}}$ via) das demais, colocando-as no local previamente estabelecido, a fim de que não ficassem misturadas com as prescrições médicas, impossibilitando desta forma, a posterior identificação, pela ausência de carimbo e assinatura, ou assinatura ilegivel do profissional.

Além de separar as prescrições odontológicas, no momento da dispensação dos medicamentos, o farmacêutico forneceu ao paciente o questionário fixado em prancheta com caneta, solicitando seu preenchimento e devolução. Depois de respondido, este foi grampeado junto com a prescrição odontológica. Nos casos nos quais outra pessoa foi buscar o(s) medicamento(s) para o paciente, ou na impossibilidade deste em responder o questionário, apenas foi recolhida a prescrição.

O questionário do paciente após ser testado em populações similares a do estudo, ficou constituído com perguntas em relação a: motivo da consulta odontológica; estado de saúde do paciente; gravidez e amamentação; se já passou mal após a utilização de algum medicamento; se faz uso de algum outro medicamento além dos prescritos pelo cirurgião-dentista; se o cirurgião-dentista perguntou sobre estas questões durante a consulta odontológica e se explicou como utilizar os medicamentos prescritos por ele. 
O objetivo deste questionário foi o de obter indícios, se o cirurgião-dentista realiza ou não anamnese, antes de efetuar alguma prescrição medicamentosa. Não houve a intenção de utilizá-lo para conhecer a situação de saúde do paciente, até porque as perguntas são bastante limitadas neste sentido. As perguntas foram formuladas no sentido de evitar confusões do paciente, entre ele ter alguma condição de saúde e o cirurgião-dentista perguntar sobre isto durante a consulta, como por exemplo: perguntou-se ao paciente se ele tinha algum outro problema de saúde, a não ser o problema no dente, e em outra pergunta, se o dentista perguntou sobre isto.

A coleta de dados nas referidas Unidades de Saúde, e a checagem do material e das possíveis dificuldades encontradas pelos funcionários da farmácia, era feita semanalmente, procedendo-se o recolhimento dos questionários respondidos pelos pacientes, efetuando-se a seguir a cópia das prescrições odontológicas em impresso apropriado para este fim (ver Anexo 3), visto que não podem ser retiradas do local.

Posteriormente pela análise dos impressos referentes à cópia das prescrições, considerou-se os erros quanto ao preenchimento e posologia, classificando-os em leves e graves.

Em relação ao preenchimento das prescrições odontológicas, foi considerado erro grave: ausência do nome do paciente ou nome incompleto; ausência do nome do medicamento; ausência de posologia, data, legibilidade e identificação profissional (nome completo do profissional + número de inscrição no Conselho Regional de Odontologia); e a utilização incorreta dos termos uso interno ou externo dos medicamentos. Foi considerado erro leve: não utilizar o nome genérico do medicamento; não mencionar a quantidade de medicamentos necessária ou indicar uma quantidade não compatível com a posologia (é rotina a correção dos dois itens anteriores pelo farmacêutico das unidades de saúde); ausência da assinatura 
profissional (visto que se tratava de $2^{\mathrm{a}}$ via); e a ausência da indicação se 0 medicamento é de uso interno ou externo (considerando que é menos grave não indicar o uso do medicamento, do que indicar de maneira incorreta).

Estando presente a posologia na prescrição, foi considerado erro grave: dose administrada incorreta (cruzando a forma de apresentação do medicamento e o tempo de administração diária, e também observando a dose diária permitida, mínima e máxima do medicamento, considerando as indicações para a Odontologia - Anexo 4); tempo de administração diária ausente ou incorreto; tempo total de administração ausente ou incorreto; e ausência da forma de apresentação do medicamento ou forma

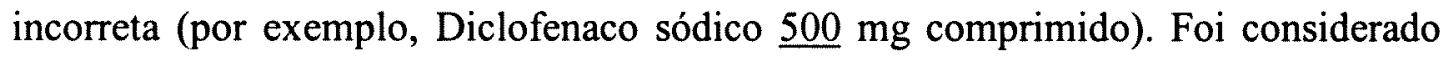
erro leve: ausência da via de administração do medicamento (através da forma de apresentação do medicamento é possível deduzir a via indicada).

Foi possível também, conhecer quais são os medicamentos mais prescritos pelos cirurgiões-dentistas e a que grupos terapêuticos pertencem. Em relação às prescrições odontológicas, analisou-se o tipo de prescrição e a quantidade de medicamentos prescritos.

\subsubsection{Análise dos prontuários de pacientes}

Dos pacientes odontológicos cujas prescrições foram separadas, foram coletadas informações dos prontuários, disponíveis pelo sistema de registro de dados informatizados da SESAU, tais como: diagnóstico de enfermidades, procedimentos efetuados e medicamentos prescritos nos atendimentos médicos, com propósito de detectar se houve alguma prescrição odontológica inadequada em relação à idade, ao estado de saúde do paciente ou ao tipo de medicamentos prescritos, o que sem dúvidas pode sinalizar se o cirurgião-dentista realiza ou não a anamnese do paciente, 
confrontando assim com as respostas dos pacientes obtidas através do questionário anteriormente descrito.

\subsection{Análise estatística}

Com a finalidade de testar a consistência dos achados provenientes das variáveis aleatórias utilizadas no estudo, foram realizados testes estatísticos.

Para a verificação de possíveis associações entre duas variáveis aleatórias, foi utilizado o Teste Qui-quadrado. Foram consideradas associações estatisticamente significantes aquelas que apresentaram valores de $p$ (probabilidade de significância) iguais ou menores do que $5 \%(0,05)$, em distribuição bicaudal. Utilizou-se também teste de comparação de proporções. Para o processamento dos dados foi utilizado o software Epi Info - versão 6 (CENTERS FOR DISEASE CONTROL, WORLD HEALTH ORGANIZATION, 1990). 


\section{RESULTADOS}

\subsection{Questionários respondidos pelos cirurgiões-dentistas (CD)}

Dos 188 questionários distribuídos, 29 não foram preenchidos, devido à ausência do profissional no dia da coleta (licença médica, licença maternidade, férias etc., e apenas uma recusa). Diante disto, obteve-se 159 questionários respondidos, correspondendo a $85 \%$ do total. Os resultados estão descritos nas tabelas de 1 a 4 e quadros de 5 a 9.

\section{Tabela 1}

Número e porcentagem de respostas dos cirurgiões-dentistas, segundo formação, tempo de trabalho, se realiza ou não plantões, SESAU/Campo Grande-MS, 2000.

\begin{tabular}{lrr}
\hline Variáveis & $\mathbf{N}^{\mathbf{0}}$ & \multicolumn{1}{c}{$\%$} \\
\hline Anos de formado & 1 & 0,6 \\
NR* & 88 & 55,4 \\
Mais do que 15 anos & 70 & 44,0 \\
Entre 5 e 15 anos & 3 & 1,9 \\
Curso de pós-graduação (concluído ou ainda cursando) & 84 & 52,8 \\
NR & 72 & 45,3 \\
Não & & \\
Sim & 1 & 0,6 \\
Tempo de Trabalho & 84 & 52,8 \\
NR & 50 & 31,5 \\
Entre 5 e 15 anos & 24 & 15,1 \\
Mais de 15 anos & & \\
Menos de 5 anos & 3 & 1,9 \\
Plantões & 105 & 66,0 \\
NR & 51 & 32,1 \\
Sim & & \\
Não & & \\
\hline
\end{tabular}

${ }^{*} \mathrm{NR}$ = não respondeu a esta pergunta. 


\section{Tabela 2}

Número e porcentagem de respostas dos cirurgiões-dentistas, segundo conhecimento sobre farmacologia na graduação, cursos e outros, SESAU/Campo Grande-MS, 2000.

\begin{tabular}{|c|c|c|}
\hline Variáveis & $\mathbf{N}^{\mathbf{0}}$ & $\%$ \\
\hline \multicolumn{3}{|l|}{ Conteúdo sobre farmacologia oferecido na graduação } \\
\hline $\mathrm{NR}^{*}$ & 16 & 10,1 \\
\hline Insuficiente & 101 & 63,5 \\
\hline Suficiente & 42 & 26,4 \\
\hline \multicolumn{3}{|l|}{ Recorrer a algum auxílio (livros etc.) para prescrever } \\
\hline NR & 2 & 1,3 \\
\hline $\operatorname{Sim}$ & 131 & 82,4 \\
\hline Não & 26 & 16,3 \\
\hline \multicolumn{3}{|l|}{$\begin{array}{l}\text { Participação em cursos relacionados à prescrição } \\
\text { odontológica }\end{array}$} \\
\hline NR & 2 & 1,3 \\
\hline Sim & 128 & 80,5 \\
\hline Não & 29 & 18,2 \\
\hline \multicolumn{3}{|l|}{$\begin{array}{l}\text { Se a SESAU oferece algum tipo de auxílio (guia etc.) para } \\
\text { a prescrição odontológica }\end{array}$} \\
\hline NR & 4 & 2,5 \\
\hline Não & 89 & 56,0 \\
\hline Sim & 66 & 41,5 \\
\hline \multicolumn{3}{|l|}{ Se o CD conhece a lista de medicamentos da SESAU } \\
\hline Sim & 111 & 69,8 \\
\hline Não & 48 & 30,2 \\
\hline
\end{tabular}

* NR = não respondeu a esta pergunta. 


\section{Tabela 3}

Participação dos cirurgiões-dentistas em cursos sobre prescrição odontológica nos últimos 12 meses, carga horária e responsável pela promoção dos cursos, SESAU/Campo Grande-MS, 2000.

\begin{tabular}{|c|c|c|}
\hline Variáveis & $\mathbf{N}^{\mathbf{0}}$ & $\%$ \\
\hline \multicolumn{3}{|c|}{$\begin{array}{l}\text { Participação em algum curso de prescrição nos últimos } 12 \\
\text { meses }\end{array}$} \\
\hline NR* & 2 & 1,2 \\
\hline Sim & 110 & 69,2 \\
\hline Não & 47 & 29,6 \\
\hline \multicolumn{3}{|l|}{ Carga horária } \\
\hline NR & 19 & 17,3 \\
\hline 8 horas & 40 & 36,4 \\
\hline 4 horas & 38 & 34,5 \\
\hline 12 horas & 12 & 10,9 \\
\hline 3 horas & 1 & 0,9 \\
\hline \multicolumn{3}{|l|}{ Quem promoveu } \\
\hline NR & 19 & 17,3 \\
\hline SESAU & 47 & 42,7 \\
\hline Congressos, Jornadas e similares & 28 & 25,5 \\
\hline $\mathrm{CRO}-\mathrm{MS}^{1}$ & 12 & 10,9 \\
\hline $\mathrm{ABO}-\mathrm{MS}^{2}$ & 3 & 2,7 \\
\hline Curso pela Internet & 1 & 0,9 \\
\hline
\end{tabular}




\section{Quadro 5}

Porcentagem de $\mathrm{CD}(\mathrm{s})$ em relação à atitude de pedir autorização ao médico para utilizar medicamentos em pacientes com algum problema de saúde (pressão alta, diabetes, cardiopatias etc.), SESAU/Campo Grande- MS, 2000.

\begin{tabular}{|l|l|}
\hline Atitude do CD em pedir autorização & \multicolumn{1}{|c|}{ Motivo } \\
\hline $\begin{array}{l}\mathbf{7 1 , 7} \% \text { dos CD(s) (114) quando } \\
\text { necessário, a depender do quadro do } \\
\text { paciente }\end{array}$ & $\begin{array}{l}\text { Para dividir responsabilidades, no entanto, } \\
\text { mais no sentido de troca de idéias com o } \\
\text { médico, dado que este profissional pode } \\
\text { ter mais informações sobre o estado de } \\
\text { saúde do paciente }\end{array}$ \\
\hline $\begin{array}{l}\mathbf{2 4 , 5} \% \text { dos CD(s) (39) responderam } \\
\text { que sempre pedem }\end{array}$ & $\begin{array}{l}\text { Por considerarem que esta atitude dá maior } \\
\text { segurança ao profissional, pois há a } \\
\text { divisão de responsabilidade sobre o } \\
\text { tratamento do paciente com o médico, } \\
\text { evitando inclusive as interações } \\
\text { medicamentosas, } 2 \text { CD(s) responderam } \\
\text { que pedem para o próprio médico } \\
\text { prescrever, por acharem que é uma } \\
\text { responsabilidade muito grande }\end{array}$ \\
\hline $\mathbf{3 , 8} \%$ dos CD(s) (6) nunca pedem & $\begin{array}{l}\text { Pois entendem que o CD tem } \\
\text { conhecimento suficiente para prescrever }\end{array}$ \\
\hline
\end{tabular}




\section{Quadro 6}

Porcentagem de $\mathrm{CD}(\mathrm{s})$ em relação a pedir autorização para utilização de medicamentos em mulheres grávidas ou que estão amamentando, SESAU/Campo Grande-MS, 2000.

\begin{tabular}{|c|c|}
\hline Atitude do CD em pedir autorização & Motivo \\
\hline $\begin{array}{l}2,5 \% \text { dos } C D(s)(4) \text { não responderam a } \\
\text { esta pergunta }\end{array}$ & - \\
\hline $\begin{array}{l}35,8 \% \text { dos } \mathrm{CD}(\mathrm{s})(57) \text { pedem } \\
\text { dependendo do período gestacional e } \\
\text { quando a gestante apresenta algum } \\
\text { problema de saúde (pressão alta, } \\
\text { diabetes, cardiopatias etc.) }\end{array}$ & $\begin{array}{l}\text { Por considerarem dificil a prescrição de } \\
\text { medicamentos até o } 3^{\circ} \text { mês. Para que } \\
\text { fiquem protegidos de qualquer problema } \\
\text { que possa advir da medicação (interações } \\
\text { medicamentosas), para maior segurança da } \\
\text { paciente (pacientes de risco) e por ser uma } \\
\text { recomendação da SESAU (protocolo para } \\
\text { atendimento de gestantes). }\end{array}$ \\
\hline $\begin{array}{l}25,8 \% \text { dos } C D(s)(41) \text { pedem quando a } \\
\text { gestante apresenta algum problema de } \\
\text { saúde (pressão alta, diabetes, } \\
\text { cardiopatias etc.) }\end{array}$ & $\begin{array}{l}\text { Para que fiquem protegidos de qualquer } \\
\text { problema que possa advir da medicação } \\
\text { (interações medicamentosas), para maior } \\
\text { segurança da paciente (pacientes de risco) e } \\
\text { por ser uma recomendação da SESAU } \\
\text { (protocolo para atendimento de gestantes) }\end{array}$ \\
\hline $\begin{array}{l}14,5 \% \text { dos } \mathrm{CD}(\mathrm{s})(23) \text { responderam } \\
\text { que sempre pedem }\end{array}$ & $\begin{array}{l}\text { Para que fiquem protegidos de qualquer } \\
\text { problema que possa advir da medicação, } 3 \\
\mathrm{CD}(\mathrm{s}) \text { pedem para o médico prescrever, } \\
\text { pois pensam que a responsabilidade é dele }\end{array}$ \\
\hline $\begin{array}{l}10,7 \% \text { dos } \mathrm{CD}(\mathrm{s})(17) \text { pedem às vezes } \\
\text { dependendo do período gestacional }\end{array}$ & $\begin{array}{l}\text { Por considerarem dificil a prescrição de } \\
\text { medicamentos até o } 3^{\circ} \text { mês }\end{array}$ \\
\hline $10,7 \%(17)$ dos $\mathrm{CD}(\mathrm{s})$ nunca pedem & $\begin{array}{l}\text { Pois acham o CD embasado para } \\
\text { prescrever ou ainda podem consultar o } \\
\text { DEF ou o protocolo de atendimento da } \\
\text { SESAU, } 2 \text { CD(s) acham que os } \\
\text { medicamentos prescritos na Odontologia } \\
\text { não interferem no feto ou na mãe. }\end{array}$ \\
\hline
\end{tabular}




\section{Quadro 7}

Porcentagem de $\mathrm{CD}(\mathrm{s})$ em relação a seguir ou não a autorização por escrito do médico, da prescrição de medicamentos para pacientes com problemas de saúde ou mulheres grávidas ou que estão amamentando, SESAU/Campo Grande-MS, 2000.

\begin{tabular}{|c|c|}
\hline $\begin{array}{l}\text { Atitude do CD em seguir às orientações } \\
\text { médicas }\end{array}$ & Motivo \\
\hline $\begin{array}{l}4,4 \% \text { dos } C D(s)(7) \text { não responderam a } \\
\text { esta pergunta }\end{array}$ & - \\
\hline $\begin{array}{l}57,2 \%(91) \text { voltam a questionar o } \\
\text { médico, se não concordam com alguma } \\
\text { orientação }\end{array}$ & $\begin{array}{l}\text { Pensam que deve haver concordância nas } \\
\text { opiniões dos profissionais, visto que o CD } \\
\text { tem conhecimento suficiente para } \\
\text { questionar o médico e para prescrever } \\
\text { medicamentos que não trarão maleficios } \\
\text { ao paciente, e que também o médico nem } \\
\text { sempre está com a razão, dado que } \\
\text { conhece pouco certos medicamentos } \\
\text { utilizados na Odontologia (por exemplo: } \\
\text { anestésicos) }\end{array}$ \\
\hline $\begin{array}{l}37,8 \%(60) \text { sempre seguem } \\
\text { independentemente se concordam ou } \\
\text { não }\end{array}$ & $\begin{array}{l}\text { Para não assumir a responsabilidade sobre } \\
\text { quaisquer conseqüências do tratamento, } \\
\text { porque consideram muito difícil a troca de } \\
\text { idéias com o médico e que jamais o } \\
\text { paciente concordará com o CD e } \\
\text { discordará do médico }\end{array}$ \\
\hline $\begin{array}{l}0,6 \% \text { (1) não leva em conta as } \\
\text { orientações fornecidas pelo médico }\end{array}$ & - \\
\hline
\end{tabular}




\section{Quadro 8}

Porcentagem de $\mathrm{CD}(\mathrm{s})$ em relação a ter ou não disponibilidade de dados sobre a saúde geral do paciente do prontuário médico da Unidade de Saúde, no momento do atendimento odontológico, SESAU/Campo Grande-MS, 2000.

\begin{tabular}{|l|l|}
\hline Disponibilidade de dados & \multicolumn{1}{|c|}{ Motivo } \\
\hline $\begin{array}{l}\text { 2,5 \% dos CD(s) (4) não responderam a } \\
\text { esta pergunta }\end{array}$ & \multicolumn{1}{|c|}{-} \\
\hline $\mathbf{6 7 , 3} \%$ dos CD(s) (107) - Não & $\begin{array}{l}\text { O acesso do prontuário do paciente só é } \\
\text { possivel nas Unidades de Saúde que estão } \\
\text { interligados com a rede de computação da } \\
\text { SESAU. Nas unidades que estão } \\
\text { interligadas, este procedimento não é } \\
\text { rotina; o CD tem que solicitar a } \\
\text { impressão do prontuário completo do } \\
\text { paciente, no entanto pode ocorrer da } \\
\text { auxiliar não saber acessá-lo, ou de não } \\
\text { haver tempo hábil para isto. }\end{array}$ \\
\hline $\mathbf{3 0 , 2} \%$ dos CD(s) (48) - Sim & $\begin{array}{l}\text { Apenas quando o CD solicita para que } \\
\text { seja impresso o prontuário completo do } \\
\text { paciente, no entanto pode ocorrer da } \\
\text { auxiliar não saber acessá-lo, ou do } \\
\text { mesmo apresentar dados restritos. }\end{array}$ \\
\hline
\end{tabular}




\section{Quadro 9}

Porcentagem de $\mathrm{CD}(\mathrm{s})$ que registram diagnóstico e medicamentos prescritos após o atendimento odontológico, SESAU/Campo Grande-MS, 2000.

\begin{tabular}{|c|c|}
\hline $\begin{array}{l}\text { Registro de diagnóstico e } \\
\text { medicamentos prescritos }\end{array}$ & Motivo \\
\hline $\begin{array}{l}3,2 \% \text { dos } \mathrm{CD}(\mathrm{s})(5) \text { não } \\
\text { responderam a esta pergunta }\end{array}$ & - \\
\hline $\begin{array}{l}50,3 \% \text { dos } \mathrm{CD}(\mathrm{s})(80) \text { não } \\
\text { registram }\end{array}$ & $\begin{array}{l}\text { Não há prontuário ou ficha clínica própria e } \\
\text { adequada para fazer anotações, não há campo } \\
\text { específico no registro informatizado de dados } \\
\text { da SESAU (mesmo se anotar na ficha de } \\
\text { atendimento, as informações não são } \\
\text { digitadas). No serviço público, não há } \\
\text { preocupação com isso, apenas com o número } \\
\text { de pacientes atendidos (não há orientações da } \\
\text { Coordenação Odontológica para efetuar estes } \\
\text { registros). Não faz parte da rotina (escassez } \\
\text { de tempo); falta de costume e negligência. }\end{array}$ \\
\hline $46,5 \%$ dos $\mathrm{CD}(\mathrm{s})(74)$ registram & $\begin{array}{l}\text { É realizado o registro no atendimento do } \\
\text { ambulatório, utilizando fichas clínicas, no } \\
\text { plantão não é possível, pois não há fichas } \\
\text { clínicas, apenas o registro dos procedimentos, } \\
\text { via computador }\end{array}$ \\
\hline
\end{tabular}




\section{Tabela 4}

Número e porcentagem das respostas corretas e incorretas dos cirurgiões-dentistas, em relação a questões sobre medicamentos e posologia, SESAU/Campo GrandeMS, 2000.

\begin{tabular}{|c|c|c|c|c|c|c|c|c|}
\hline \multirow[t]{3}{*}{ Questões } & \multicolumn{6}{|c|}{ Respostas } & \multirow{2}{*}{\multicolumn{2}{|c|}{ Total }} \\
\hline & \multicolumn{2}{|c|}{ Corretas } & \multicolumn{2}{|c|}{ Incorretas } & \multicolumn{2}{|c|}{ NR* } & & \\
\hline & $\mathbf{N}^{0}$ & $\%$ & $\mathbf{N}^{0}$ & $\%$ & $\mathbf{N}^{0}$ & $\%$ & $\mathbf{N}^{\mathbf{0}}$ & $\%$ \\
\hline $\begin{array}{l}\text { Grávida alérgica à } \\
\text { penicilina com dor }\end{array}$ & 107 & 67,3 & 44 & 27,7 & 8 & 5,0 & 159 & 100,0 \\
\hline $\begin{array}{l}\text { Criança com dor e } \\
\text { febre }\end{array}$ & 100 & 62,9 & 56 & 35,2 & 3 & 1,9 & 159 & 100,0 \\
\hline $\begin{array}{l}\text { Adulto diabético com } \\
\text { dor e infecção }\end{array}$ & 122 & 76,7 & 28 & 17,6 & 9 & 5,7 & 159 & 100,0 \\
\hline $\begin{array}{l}\text { Medicamentos contra- } \\
\text { indicados na } \\
\text { amamentação }\end{array}$ & 92 & 57,9 & 60 & 37,7 & 7 & 4,4 & 159 & 100,0 \\
\hline Total & 421 & 66,2 & 188 & 29,6 & 27 & 4,2 & 636 & 100,0 \\
\hline
\end{tabular}

A fim de verificar se as variáveis aleatórias: conteúdo oferecido na graduação, anos de formado, pós-graduação, participação em cursos sobre prescrição medicamentosa antes ou nos últimos 12 meses, se recorre a algum auxílio para prescrever medicamentos, tempo de trabalho na rede Pública, plantões, são independentes dos erros e acertos dos $C D(s)$, procedeu-se a realização do teste quiquadrado ao nível de significância de 5\% (ver Tabelas 5 e 6, Quadro 10), cujos resultados estão demonstrados a seguir: 


\section{Tabela 5}

Número e porcentagem de respostas corretas e incorretas dos cirurgiões-dentistas, em relação a questões sobre medicamentos e posologia, segundo formação, tempo de trabalho, se realiza ou não plantões, Campo Grande-MS, 2000.

\begin{tabular}{|c|c|c|c|c|c|c|c|c|}
\hline \multirow{3}{*}{ Variáveis } & \multicolumn{6}{|c|}{ Respostas } & \multirow{2}{*}{\multicolumn{2}{|c|}{ Total }} \\
\hline & \multicolumn{2}{|c|}{ Corretas } & \multicolumn{2}{|c|}{ Incorretas } & \multicolumn{2}{|c|}{$\mathbf{N R}^{*}$} & & \\
\hline & $\mathbf{N}^{0}$ & $\%$ & $\mathbf{N}^{\mathbf{0}}$ & $\%$ & $\mathbf{N}^{\mathbf{o}}$ & $\%$ & $\mathbf{N}^{\mathbf{0}}$ & $\%$ \\
\hline \multicolumn{9}{|l|}{ Anos de formado } \\
\hline NR & 3 & 75,0 & 1 & 25,0 & - & - & 4 & 100,0 \\
\hline Entre 5 e 15 anos & 192 & 68,6 & 78 & 27,8 & 10 & 3,6 & 280 & 100,0 \\
\hline Mais do que 15 anos & 226 & 64,2 & 109 & 31,0 & 17 & 4,8 & 352 & 100,0 \\
\hline \multicolumn{9}{|l|}{$\begin{array}{l}\text { Curso de pós-graduação } \\
\text { (concluído ou ainda cursando) }\end{array}$} \\
\hline NR & 8 & 67,0 & 4 & 33,0 & - & - & 12 & 100,0 \\
\hline Sim & 199 & 69,1 & 76 & 26,4 & 13 & 4,5 & 288 & 100,0 \\
\hline Não & 214 & 63,7 & 108 & 32,1 & 14 & 4,2 & 336 & 100,0 \\
\hline \multicolumn{9}{|l|}{ Tempo de Trabalho } \\
\hline NR & 2 & 50,0 & 2 & 50,0 & - & - & 4 & 100,0 \\
\hline Menos de 5 anos & 69 & 71,9 & 26 & 27,1 & 1 & 1,0 & 96 & 100,0 \\
\hline Entre 5 e 15 anos & 231 & 68,7 & 95 & 28,3 & 10 & 3,0 & 336 & 100,0 \\
\hline Mais de 15 anos & 119 & 59,5 & 65 & 32,5 & 16 & 8,0 & 200 & 100,0 \\
\hline \multicolumn{9}{|l|}{ Plantões } \\
\hline NR & 7 & 58,3 & 5 & 41,7 & - & - & 12 & 100,0 \\
\hline Sim & 284 & 67,6 & 124 & 29,5 & 12 & 2,9 & 420 & 100,0 \\
\hline Não & 130 & 63,7 & 59 & 28,9 & 15 & 7,4 & 204 & 100,0 \\
\hline
\end{tabular}

* NR = não respondeu a esta pergunta 


\section{Tabela 6}

Número e porcentagem de respostas corretas e incorretas dos cirurgiões-dentistas, em relação a questões sobre medicamentos e posologia, segundo conhecimento sobre farmacologia na graduação, cursos e outros, Campo Grande-MS, 2000.

\begin{tabular}{|c|c|c|c|c|c|c|c|c|}
\hline \multirow{3}{*}{ Variáveis } & \multicolumn{6}{|c|}{ Respostas } & \multirow{2}{*}{\multicolumn{2}{|c|}{ Total }} \\
\hline & \multicolumn{2}{|c|}{ Corretas } & \multicolumn{2}{|c|}{ Incorretas } & \multicolumn{2}{|c|}{ NR* } & & \\
\hline & $\mathbf{N}^{\mathbf{0}}$ & $\%$ & $\mathbf{N}^{0}$ & $\%$ & $\mathbf{N}^{\mathbf{0}}$ & $\%$ & $\mathbf{N}^{0}$ & $\%$ \\
\hline \multicolumn{9}{|c|}{$\begin{array}{l}\text { Conteúdo sobre farmacologia } \\
\text { oferecido na graduação }\end{array}$} \\
\hline NR & 40 & 62,5 & 22 & 34,4 & 2 & 3,1 & 64 & 100,0 \\
\hline Suficiente & 118 & 70,2 & 47 & 28,0 & 3 & 1,8 & 168 & 100,0 \\
\hline Insuficiente & 263 & 65,1 & 119 & 29,5 & 22 & 5,4 & 404 & 100,0 \\
\hline \multicolumn{9}{|c|}{$\begin{array}{l}\text { Recorrer a algum auxílio } \\
\text { (livros etc.) para prescrever }\end{array}$} \\
\hline NR & 5 & 62,5 & 3 & 37,5 & - & - & 8 & 100,0 \\
\hline Sim & 348 & 66,4 & 157 & 30,0 & 19 & 3,6 & 524 & 100,0 \\
\hline Não & 68 & 65,4 & 28 & 26,9 & 8 & 7,7 & 104 & 100,0 \\
\hline \multicolumn{9}{|c|}{$\begin{array}{l}\text { Participação em cursos } \\
\text { relacionados à prescrição } \\
\text { odontológica }\end{array}$} \\
\hline NR & 6 & 75,0 & 2 & 25,0 & - & - & 8 & 100,0 \\
\hline Sim & 345 & 67,4 & 147 & 28,7 & 20 & 3,9 & 512 & 100,0 \\
\hline Não & 70 & 60,4 & 39 & 33,6 & 7 & 6,0 & 116 & 100,0 \\
\hline \multicolumn{9}{|c|}{$\begin{array}{l}\text { Participação em algum curso } \\
\text { de prescrição nos últimos } 12 \\
\text { meses }\end{array}$} \\
\hline NR & 5 & 62,5 & 1 & 12,5 & 2 & 25,0 & 8 & 100,0 \\
\hline Sim & 301 & 68,4 & 128 & 29,1 & 11 & 2,5 & 440 & 100,0 \\
\hline Não & 115 & 61,2 & 59 & 31,4 & 14 & 7,4 & 188 & 100,0 \\
\hline
\end{tabular}

* NR = não respondeu a esta pergunta 


\section{Quadro 10}

Valores do Quiquadrado* $\left(\chi^{2}\right)$ com a respectiva interpretação, para as variáveis aleatórias do estudo sobre prescrição de medicamentos, Campo Grande-MS, 2000.

\begin{tabular}{|l|c|c|c|}
\hline Variáveis aleatórias & Valores do $\chi^{\mathbf{2}}$ & $\mathbf{p}$ & Independência \\
\hline Anos de formado & 1,33 & 0,2492 & sim \\
\hline Pós-graduação & 2,03 & 0,1547 & sim \\
\hline Tempo de trabalho & 6,38 & 0,0412 & não \\
\hline Plantão & 0,93 & 0,3343 & sim \\
\hline Conteúdo graduação & 1,41 & 0,2352 & sim \\
\hline Auxílio para prescrever & 0,04 & 0,8396 & sim \\
\hline Cursos sobre prescrição & 2,09 & 0,1483 & sim \\
\hline Cursos sobre prescrição - últimos 12 meses & 3,09 & 0,0789 & sim \\
\hline
\end{tabular}

* para o cálculo do quiquadrado: (a) foram excluídos os dados referentes aos que não responderam às perguntas (NR) em relação às variáveis aleatórias; (b) em relação às questões sobre medicamentos e posologia, foram somadas as perguntas não respondidas (NR) e as respostas incorretas, considerando que os $\mathrm{CD}(\mathrm{s})$ que não responderam a determinada questão, tinham dúvidas sobre a prescrição, errando portanto, pela omissão da resposta. 


\subsection{Análise das prescriçð̃es odontológicas e questionário dirigido aos}

\section{pacientes}

Foram analisadas 509 prescrições odontológicas, cujos resultados estão descritos a seguir. Em relação aos erros de preenchimento, vide Tabela 7 e 8.

\section{Tabela 7}

Número e porcentagem de preenchimentos corretos e incorretos, em prescrições odontológicas de Unidades de Saúde de Campo Grande - MS, 2000.

\begin{tabular}{llc}
\hline Preenchimento & $\mathbf{N}^{\mathbf{0}}$ & $\%$ \\
\hline Correto & 108 & 21,2 \\
Incorreto & 401 & 78,8 \\
\hline Total & 509 & 100,0 \\
\hline
\end{tabular}

\section{Tabela 8}

Número e porcentagem* dos tipos de erros de preenchimento em prescrições odontológicas de Unidades de Saúde de Campo Grande - MS, 2000.

\begin{tabular}{r|l|r|r}
\hline Erro & \multicolumn{1}{|c|}{ Descrição } & $\mathbf{N}^{\mathbf{0}}$ & \multicolumn{1}{c}{$\%$} \\
\hline Grave & Ausência de data & 92 & 18,1 \\
& Ausência de identificação profissional & 72 & 14,1 \\
& Nome do paciente incompleto & 16 & 3,1 \\
& Ausência de legibilidade & 13 & 2,6 \\
& Utilizar uso interno ou externo incorretamente & 8 & 1,6 \\
& Ausência de posologia & 3 & 0,6 \\
& Ausência do nome do paciente & 1 & 0,2 \\
\hline Leve & Quantidade da medicação incorreta ou ausente & 368 & 72,3 \\
& Ausência do modo de usar o medicamento - uso interno ou & 64 & 12,6 \\
& externo & & \\
& A não utilização do nome genérico do medicamento & 27 & 5,3 \\
& Ausência de assinatura profissional & 5 & 1,0 \\
\hline
\end{tabular}

\footnotetext{
* Porcentagem relativa ao total de 509 prescrições, sendo que cada prescrição pode apresentar mais de um tipo de erro.
} 
Em relação aos erros de posologia, vide Tabela 9 e 10.

\section{Tabela 9}

Número e porcentagem de posologias* corretas e incorretas, em prescrições odontológicas de Unidades de Saúde de Campo Grande - MS, 2000.

\begin{tabular}{lcc}
\hline Posologia & $\mathbf{N}^{\mathbf{0}}$ & $\%$ \\
\hline Correta & 129 & 25,3 \\
Incorreta & 380 & 74,7 \\
\hline Total & 509 & 100,0 \\
\hline * Foram excluídos desta & Tabela os dados referentes à via de \\
administração. &
\end{tabular}

\section{Tabela 10}

Número e porcentagem* dos tipos de erros de posologia em prescrições odontológicas de Unidades de Saúde de Campo Grande - MS, 2000.

\begin{tabular}{l|l|c|c}
\hline Erro & \multicolumn{1}{|c|}{ Descrição } & $\mathbf{N}^{\mathbf{0}}$ & $\%$ \\
\hline Grave & Tempo de administração diária ausente ou incorreto & 237 & 46,6 \\
& Forma de apresentação ausente ou incorreta & 181 & 35,6 \\
& Tempo total de administração ausente ou incorreto & 164 & 32,2 \\
& Dose administrada incorreta & 160 & 31,4 \\
\hline Leve & Via de administração ausente & 489 & 96,1 \\
\hline " Porcentagem relativa ao total de 509 prescrições, sendo que cada prescrição \\
pode apresentar mais de um tipo de erro.
\end{tabular}

Para fim de comparação com estudo anterior (mesmo universo), PINTO (1998), foram elaboradas as Tabelas 7 e 9, seguindo o mesmo procedimento metodológico do referido trabalho, no qual: (a) não houve a classificação dos erros em leves ou graves; (b) a prescrição foi considerada incorreta na presença de um ou mais erros e (c) não foi analisado nenhum aspecto em relação à via de administração.

Foram prescritos 771 medicamentos, em 509 prescrições odontológicas, conforme Tabela 11. Do total de medicamentos (771), apenas 4,8 \% (37) não 
constam na lista de medicamentos da SESAU / Campo Grande - MS. Na posologia, o esquema "tome ... se sentir dor", ocorreu em: em 52,3\% (126) de 241 prescrições de analgésicos não-opióides; em 2,5 \% (6) de 238 prescrições de Diclofenaco (referente a todas as formas de apresentação); e em $0,3 \%$ (1) de 290 prescrições de antibiótico.

Neste estudo, o ácido acetilsalicílico foi considerado somente como analgésico não-opióide, visto que não foram encontradas, nas prescrições odontológicas observadas, doses suficientes para conseguir efeito antiinflamatório. $\mathrm{O}$ diclofenaco, apesar de ser classificado na literatura como antiinflamatório nãoesteróide e também como analgésico não-opióide, foi considerado como antiinflamatório, devido a indicações específicas, já discutidas anteriormente (vide capítulo da Introdução).

De 20 prescrições de Penicilina injetável, em $60 \%$ (12), o profissional solicitou que fosse feito o teste de sensibilidade; destes 12 pacientes, o cirurgiãodentista perguntou para 2, se passavam mal utilizando algum medicamento, 5 não foram questionados a respeito e 5 não foi possível saber (pacientes não responderam ao questionário). Estes 20 antibióticos injetáveis, representaram: 6,9\% de 290 antibióticos prescritos, e $45,5 \%$ de 44 medicamentos injetáveis prescritos.

$\mathrm{Na}$ tabela 12, tem-se a distribuição de medicamentos segundo grupo terapêutico, na tabela 13 , por tipo de prescrição e na tabela 14 , por quantidade de medicamentos prescritos. 


\section{Tabela 11}

Número e porcentagem* dos medicamentos em relação às prescrições odontológicas de Unidades de Saúde de Campo Grande - MS, 2000.

\begin{tabular}{|c|c|c|}
\hline Medicamento prescrito & $\mathbf{N}^{\mathbf{0}}$ & $\%$ \\
\hline Diclofenaco sódico $50 \mathrm{mg}$ & 203 & 39,9 \\
\hline Ampicilina $500 \mathrm{mg}$ & 191 & 37,5 \\
\hline Paracetamol $500 \mathrm{mg}$ & 94 & 18,5 \\
\hline Dipirona $500 \mathrm{mg} / \mathrm{ml}$ gotas & 77 & 15,1 \\
\hline Diclofenaco $10 \mathrm{mg} / \mathrm{ml}$ gotas $* *$ & 32 & 6,3 \\
\hline Paracetamol $200 \mathrm{mg} / \mathrm{ml}$ gotas & 29 & 5,7 \\
\hline Cefalexina $500 \mathrm{mg}$ & 27 & 5,3 \\
\hline Ampicilina $250 \mathrm{mg} / 5 \mathrm{ml}$ suspensão & 22 & 4,3 \\
\hline Penicilina G Benzatina 1.200.000 UI frasco/ampola & 20 & 3,9 \\
\hline Dipirona $500 \mathrm{mg}$ injetável ampola $2 \mathrm{ml}$ & 19 & 3,7 \\
\hline Ácido Acetil Salicílico $500 \mathrm{mg}$ & 15 & 2,9 \\
\hline Eritromicina $250 \mathrm{mg}$ & 7 & 1,4 \\
\hline Ácido Acetil Salicílico $100 \mathrm{mg}$ & 6 & 1,2 \\
\hline Tetraciclina $250 \mathrm{mg}$ & 6 & 1,2 \\
\hline Metronidazol $250 \mathrm{mg}$ & 6 & 1,2 \\
\hline Ampicilina $250 \mathrm{mg} * *$ & 4 & 0,8 \\
\hline Diclofenaco $75 \mathrm{mg}$ injetável ampola $3 \mathrm{ml}$ & 3 & 0,6 \\
\hline Cloranfenicol $250 \mathrm{mg}$ & 3 & 0,6 \\
\hline Eritromicina $2,5 \%$ suspensão & 2 & 0,4 \\
\hline Cefalexina $250 \mathrm{mg} / 5 \mathrm{ml}$ suspensão & 2 & 0,4 \\
\hline Ácido Tramexamico $250 \mathrm{mg}$ injetável ampola $5 \mathrm{ml}$ & 2 & 0,4 \\
\hline Dipirona $500 \mathrm{mg} * *$ & 1 & 0,2 \\
\hline
\end{tabular}




\section{Tabela 12}

Número e porcentagem* dos medicamentos em relação às prescrições odontológicas, segundo grupos terapêuticos, nas Unidades de Saúde de Campo Grande - MS, 2000.

\begin{tabular}{lrr}
\hline Grupos Terapêuticos & $\mathbf{N}^{\mathbf{0}}$ & $\mathbf{\%}$ \\
\hline Antibióticos & 290 & 57,0 \\
Analgésicos não opióides & 241 & 47,3 \\
Antiinflamatórios não-esteróides & 238 & 46,8 \\
Hemostático - uso sistêmico & 2 & 0,4 \\
\hline * Porcentagem relativa ao total de 509 prescrições, visto que cada \\
prescrição pode conter mais de um grupo terapêutico.
\end{tabular}

\section{Tabela 13}

Número e porcentagem das prescrições odontológicas, segundo tipo de prescrição, nas Unidades de Saúde de Campo Grande - MS, 2000.

\begin{tabular}{|c|c|c|}
\hline Tipo de prescrição & $\mathrm{N}^{\mathrm{O}}$ & $\%$ \\
\hline Somente antibiótico & 101 & 19,8 \\
\hline Somente antiinflamatório não-esteróide & 86 & 16,9 \\
\hline Analgésico não-opióide + antibiótico & 82 & 16,1 \\
\hline Antiinflamatório não-esteróide + antibiótico & 80 & 15,7 \\
\hline Somente analgésico não-opióide & 77 & 15,1 \\
\hline Analgésico não-opióide + antiinflamatório não-esteróide & 55 & 10,8 \\
\hline $\begin{array}{l}\text { Analgésico não-opióide + antiinflamatório não-esteróide }+ \\
\text { antibiótico }\end{array}$ & 11 & 2,2 \\
\hline Antibiótico + antibiótico + analgésico não-opióide ${ }^{1}$ & 5 & 1,0 \\
\hline Analgésico não-opióide + analgésico não-opióide ${ }^{2}$ & 3 & 0,6 \\
\hline Antibiótico + antibiótico ${ }^{3}$ & 2 & 0,4 \\
\hline $\begin{array}{l}\text { Antiinflamatório não-esteróide + Antiinflamatório não- } \\
\text { esteróide }{ }^{4}\end{array}$ & 2 & 0,4 \\
\hline Somente hemostático & 2 & 0,4 \\
\hline $\begin{array}{l}\text { Analgésico não-opióide }+ \text { analgésico não-opióide }+ \\
\text { antibiótico }\end{array}$ & 1 & 0,2 \\
\hline $\begin{array}{l}\text { Analgésico não-opióide }+ \text { analgésico não-opióide }+ \\
\text { analgésico não-opióide }{ }^{6}\end{array}$ & 1 & 0,2 \\
\hline $\begin{array}{l}\text { Antiinflamatório não-esteróide }+ \text { antiinflamatório não- } \\
\text { esteróide }+ \text { antibiótico }\end{array}$ & 1 & 0,2 \\
\hline Total & 509 & 100,0 \\
\hline
\end{tabular}

1 Ampicilina + metronidazol + analgégico não-opióide (3)

Ampicilina comprimido + penicilina injetável + analgésico não-opióide (2)

2 Ácido acetilsalićlico + paracetamol (2)

Ácido acetilsalicílico + dipirona (1)

3 Ampicilina + metronidazol (1) / Tetraciclina + metronidazol (1)

4 Diclofenaco via oral + diclofenaco injetável (2)

5 Dipirona injetável + paracetamol + ampicilina

6 Dipirona injetável + dipirona gotas + paracetamol

7 Diclofenaco via oral + diclofenaco injetável + penicilina injetável 


\section{Tabela 14}

Número e porcentagem prescrições odontológicas, segundo a quantidade de medicamentos prescritos, em Unidades de Saúde de Campo Grande-MS, 2000.

\begin{tabular}{l|r|r}
\hline Quantidade de medicamentos & $\mathbf{N}^{\mathbf{0}}$ & \multicolumn{1}{c}{$\%$} \\
\hline Um medicamento & 263 & 51,7 \\
Dois medicamentos & 220 & 43,2 \\
Três medicamentos & 26 & 5,1 \\
\hline Total & 509 & 100,0 \\
\hline
\end{tabular}

Dos 509 pacientes que procuraram a farmácia das Unidades de Saúde, 63,7 \% (324) responderam ao questionário fornecido no momento da dispensação dos medicamentos e 36,3 \% (185), não responderam. Os resultados, que serão analisados no capítulo da discussão, estão descritos nas Tabelas 15,16 e 17, os demais constam no Anexo 5.

\section{Tabela 15}

Número e porcentagem das respostas em relação aos motivos que levaram os pacientes a procurarem o atendimento odontológico, em Unidades de Saúde de Campo Grande - MS, 2000.

\begin{tabular}{lrr}
\hline \multicolumn{1}{c}{ Motivo } & $\mathbf{N}^{\mathbf{0}}$ & \multicolumn{1}{c}{$\%$} \\
\hline NR* & 25 & 7,8 \\
Dor & 174 & 53,7 \\
Tratamento odontológico & 59 & 18,2 \\
Extração & 34 & 10,5 \\
Inflamação & 24 & 7,4 \\
Trauma dental (lesões por queda) & 4 & 1,2 \\
Infecção & 4 & 1,2 \\
\hline Total & 324 & 100,0 \\
\hline
\end{tabular}

* NR = não respondeu a esta pergunta 


\section{Tabela 16}

Número e porcentagem de respostas dos pacientes, em relação a se o cirurgiãodentista perguntou sobre o estado de saúde, durante o atendimento odontológico, em Unidades de Saúde de Campo Grande - MS, 2000.

\begin{tabular}{|c|c|c|c|c|c|c|c|c|}
\hline \multirow[t]{2}{*}{ Perguntas sobre } & \multicolumn{6}{|c|}{ Se o cirurgiåo-dentista perguntou } & \multicolumn{2}{|c|}{ Total } \\
\hline & NR* & $\%$ & Sim & $\%$ & Não & $\%$ & $\mathbf{N}^{\mathbf{o}}$ & $\%$ \\
\hline Problema de saúde & 8 & 2,5 & 109 & 33,6 & 207 & 63,9 & 324 & 100,0 \\
\hline $\begin{array}{l}\text { Passar mal ao utilizar algum } \\
\text { medicamento }\end{array}$ & 6 & 1,9 & 107 & 33,0 & 211 & 65,1 & 324 & 100,0 \\
\hline $\begin{array}{l}\text { Estar utilizando algum outro } \\
\text { medicamento }\end{array}$ & 7 & 2,2 & 98 & 30,2 & 219 & 67,6 & 324 & 100,0 \\
\hline Gravidez e amamentação ** & 84 & 38,2 & 45 & 20,4 & 91 & 41,4 & 220 & 100,0 \\
\hline
\end{tabular}

\section{Tabela 17}

Número e porcentagem de respostas dos pacientes, em relação a se o cirurgiãodentista explicou sobre a utilização dos medicamentos prescritos, durante o atendimento odontológico, em Unidades de Saúde de Campo Grande - MS, 2000.

\begin{tabular}{lrr}
\hline Explicação do cirurgião-dentista & \multicolumn{1}{c}{$\mathbf{N}^{\mathbf{0}}$} & \multicolumn{1}{c}{$\%$} \\
\hline NR* $^{*}$ & 4 & 1,2 \\
Sim & 264 & 81,5 \\
Não & 56 & 17,3 \\
\hline Total & 324 & 100,0 \\
\hline${ }^{*}$ NR = não respondeu a esta pergunta & &
\end{tabular}

\subsection{Análise dos prontuários de pacientes}

Dos pacientes odontológicos cujas prescrições foram separadas (509), foram coletadas informaçð̃es dos prontuários, disponíveis pelo sistema de registro de dados informatizados da SESAU. Na odontologia, foram encontrados apenas os registros dos procedimentos efetuados no paciente (não constava o diagnóstico, nem a terapêutica medicamentosa empregada); na medicina, havia dados referentes ao 
diagnóstico (Código Internacional de Doenças - CID, ORGANIZAÇÃO MUNDIAL DA SAÚDE 1993b), sintomatologia, exames complementares solicitados e terapêutica aplicada (medicamentosa ou não), no entanto, em muitos prontuários os registros estavam incompletos. Os resultados estão descritos a seguir, nas Tabelas 18 , 19 e 20 e Quadros 11, 12 e 13.

\section{Tabela 18}

Número e porcentagem de registros de enfermidades ou condições fisiológicas / anatômicas específicas de pacientes odontológicos, em prontuários de Unidades de Saúde de Campo Grande - MS, 2000.

\begin{tabular}{|c|c|c|}
\hline Enfermidades ou condições fisiológicas / anatômicas específicas & $\mathbf{N}^{\circ}$ & $\%$ \\
\hline Crianças & 67 & 13,16 \\
\hline Hipertensão ${ }^{2}$ & 24 & 4,71 \\
\hline Distúrbios gástricos & 13 & 2,55 \\
\hline Gravidez & 10 & 1,96 \\
\hline Amamentação & 10 & 1,96 \\
\hline Asma & 7 & 1,38 \\
\hline Idosos & 5 & 0,98 \\
\hline Problemas renais & 4 & 0,79 \\
\hline Hipertensão + amamentação & 3 & 0,59 \\
\hline Alterações cardiovasculares ${ }^{1}$ & 3 & 0,59 \\
\hline Diabetes $^{3}$ & 3 & 0,59 \\
\hline Epilepsia & 3 & 0,59 \\
\hline Hipertensão + distúrbios gástricos ${ }^{4}$ & 2 & 0,39 \\
\hline Hipertensão + distúrbios gástricos + alterações cardiovasculares & 1 & 0,20 \\
\hline Hipertensão + alterações cardiovasculares & 1 & 0,20 \\
\hline Hipertensão + diabetes & 1 & 0,20 \\
\hline Gravidez + distúrbios gástricos & 1 & 0,20 \\
\hline Gravidez + epilepsia & 1 & 0,20 \\
\hline Hanseníase & 1 & 0,20 \\
\hline Diabetes + Problemas renais & 1 & 0,20 \\
\hline Subtotal & 161 & 31,6 \\
\hline Sem registro & 348 & 68,4 \\
\hline Total & 509 & 100,0 \\
\hline
\end{tabular}

1 Dos 3 pacientes com alteraç̃es cardíacas, 2 são usuários crônicos de ácido acetil salicílico.

2 Dos 24 pacientes hipertensos, 2 são usuários crônicos de diclofenaco.

3 Dos 3 pacientes diabéticos, 1 é usuário crônico de prednisona.

4 Dos 2 pacientes hipertensos e com distúrbios gástricos, 1 é usuário crônico de diclofenaco. 
Dos 6 pacientes usuários crônicos de algum medicamento (ver Tabela 18), 50

\% (3) tiveram interação medicamentosa após a prescrição odontológica (dois medicamentos que provocam irritação gástrica). Em relação a se o cirurgião-dentista perguntou se estavam tomando outro medicamento, além do prescrito por ele, dos 3 pacientes, 2 não responderam o questionário e 1 respondeu que não foi indagado pelo cirurgião-dentista.

\section{Tabela 19}

Número de indicações de medicamentos inadequadas, em relação às enfermidades ou condições fisiológicas / anatômicas específicas dos pacientes odontológicos, em prontuários de Unidades de Saúde de Campo Grande - MS, 2000.

\begin{tabular}{lc}
\hline Indicaçðes inadequadas & $\mathbf{N}^{\mathbf{0}}$ \\
\hline Diclofenaco para crianças & 34 \\
Diclofenaco para hipertenso & 17 \\
Diclofenaco para pacientes com distúrbios gástricos & 7 \\
Paracetamol para pacientes com distúrbios gástricos & 7 \\
Diclofenaco para gestantes & 5 \\
Ácido Acetilsalicílico para pacientes hipertensos & 3 \\
Diclofenaco para pacientes diabéticos & 2 \\
Diclofenaco para pacientes asmáticos & 1 \\
Ácido Acetilsalicílico para pacientes diabéticos & 1 \\
Ácido Acetilsalicílico para pacientes com distúrbios gástricos & 1 \\
Tetraciclina para gestantes & 1 \\
Eritromicina para lactantes & 1 \\
\hline
\end{tabular}




\section{Tabela 20}

Número de indicações medicamentosas adequadas ou inadequadas, em relação às enfermidades ou condições de fisiológicas / anatômicas específicas dos pacientes odontológicos e faixa etária, em prontuários de Unidades de Saúde de Campo Grande - MS, 2000.

\begin{tabular}{|c|c|c|c|c|c|c|}
\hline \multirow[t]{3}{*}{ Pacientes } & \multicolumn{4}{|c|}{ Prescriçð̃es } & \multirow{2}{*}{\multicolumn{2}{|c|}{ Total }} \\
\hline & \multicolumn{2}{|c|}{ Adequadas } & \multicolumn{2}{|c|}{ Inadequadas } & & \\
\hline & $\mathbf{N}^{0}$ & $\%$ & $\mathbf{N}^{0}$ & $\%$ & $\mathbf{N}^{\mathbf{0}}$ & $\%$ \\
\hline Idosos & 5 & 100,0 & - & - & 5 & 100,0 \\
\hline Crianças & 33 & 49,3 & 34 & 50,7 & 67 & 100,0 \\
\hline $\begin{array}{l}\text { Pacientes com alguma enfermidade ou } \\
\text { condições fisiológicas / anatômicas } \\
\text { específicas }\end{array}$ & 48 & 53,9 & 41 & 46,1 & 89 & 100,0 \\
\hline Total & 86 & 53,4 & 75 & 46,6 & 161 & 100,0 \\
\hline
\end{tabular}




\section{Quadro 11}

Número de prescrições* medicamentosas coincidentes de pacientes odontológicos, segundo tipo de coincidência, profissionais envolvidos e medicamentos utilizados, em prontuários de Unidades de Saúde de Campo Grande - MS, 2000.

\begin{tabular}{|c|c|c|}
\hline Tipo de coincidência & Profissional & $\begin{array}{l}\text { Medicamento } \\
\text { coincidente }\end{array}$ \\
\hline $\begin{array}{l}\text { Prescrição do mesmo } \\
\text { medicamento, duas vezes, } \\
\text { uma para tratamento }\end{array}$ & $\begin{array}{l}\text { Cirurgião-dentista e médico } \\
\text { prescreveram no mesmo dia } \\
(2)\end{array}$ & $\begin{array}{l}\text { analgésico (1) } \\
\text { diclofenaco (1) }\end{array}$ \\
\hline $\begin{array}{l}\text { odontológico e uma para } \\
\text { tratamento médico (4) }\end{array}$ & $\begin{array}{|ll|}\text { Médico } & \text { prescreveu } \\
\text { posteriormente à } & \text { prescrição } \\
\text { odontológica (2) } & \\
\end{array}$ & antibiótico \\
\hline $\begin{array}{l}\text { Médico e cirurgião-dentista } \\
\text { prescreveram medicamentos } \\
\text { iguais para o paciente, para } \\
\text { tratamento do mesmo } \\
\text { problema bucal (1) }\end{array}$ & $\begin{array}{l}\text { Cirurgião-dentista e médico } \\
\text { prescreveram no mesmo dia }\end{array}$ & diclofenaco \\
\hline $\begin{array}{l}\text { Médico e cirurgião-dentista } \\
\text { prescreveram medicamentos } \\
\text { distintos para o paciente, } \\
\text { para tratamento do mesmo } \\
\text { problema bucal (trauma } \\
\text { bucal) (1) }\end{array}$ & $\begin{array}{l}\text { Cirurgião-dentista e médico } \\
\text { prescreveram no mesmo dia }\end{array}$ & $\begin{array}{l}\text { analgésico (médico) } \\
+ \\
\text { diclofenaco(cirurgião } \\
\text {-dentista) }\end{array}$ \\
\hline $\begin{array}{l}\text { Médico e cirurgião-dentista } \\
\text { prescreveram o mesmo } \\
\text { medicamento para o } \\
\text { paciente, para tratamento de } \\
\text { odontalgia, sendo que o } \\
\text { médico ainda prescreveu } \\
\text { mais um medicamento (1) }\end{array}$ & $\begin{array}{l}\text { Médico } \\
\text { posteriormente à prescreveção } \\
\text { odontológica }\end{array}$ & $\begin{array}{l}\text { antibiótico (médico) } \\
\quad+ \\
\text { diclofenaco (médico } \\
\text { e cirurgião dentista) }\end{array}$ \\
\hline
\end{tabular}

* A frequiência observada de prescrições coincidentes está entre parênteses.

Do total de 509 pacientes atendidos, $4,3 \%$ (22) tiveram atendimento médico e odontológico no mesmo dia, sendo que destes (22), 18,2 \% (4) tiveram prescrições coincidentes, conforme Quadro 11. Segundo informações do setor de farmácia da SESAU, para todas as prescrições que o paciente apresenta, são dispensados os medicamentos, não sendo observado se dois profissionais prescreveram o mesmo medicamento para o paciente. 


\section{Quadro 12}

Número de interações* medicamentosas de pacientes odontológicos, segundo tipo de interação e profissionais envolvidos, em prontuários de Unidades de Saúde de Campo Grande - MS, 2000.

\begin{tabular}{|c|c|}
\hline Profissional & Tipo de interação \\
\hline \multirow{2}{*}{$\begin{array}{l}\text { Médico prescreveu } \\
\text { posteriormente à } \\
\text { prescrição odontológica, } \\
\text { causando a interação } \\
\text { medicamentosa (2) }\end{array}$} & antibiótico bacteriostático + antibiótico bactericida (1) \\
\hline & dois medicamentos que causam irritação gástrica (1) \\
\hline \multirow{4}{*}{$\begin{array}{l}\text { Cirurgião-dentista } \\
\text { prescreveu } \\
\text { posteriormente à } \\
\text { prescrição médica, } \\
\text { causando a interação } \\
\text { medicamentosa (15) }\end{array}$} & antibiótico + anticoncepcional (10) \\
\hline & dois medicamentos que causam irritação gástrica (3) \\
\hline & $\begin{array}{l}\text { antibiótico + anticoncepcional e também dois } \\
\text { medicamentos que causam irritação gástrica (1) }\end{array}$ \\
\hline & penicilina e derivados + fenitoína - anticonvulsivante (1) \\
\hline $\begin{array}{l}\text { Médico e cirurgião- } \\
\text { dentista prescreveram no } \\
\text { mesmo dia, ocorrendo a } \\
\text { interação } \\
\text { medicamentosa (2) }\end{array}$ & dois medicamentos que causam irritação gástrica \\
\hline \multirow{2}{*}{$\begin{array}{l}\text { Cirurgião-dentista } \\
\text { prescreveu dois } \\
\text { medicamentos que } \\
\text { interagem entre si (59) }\end{array}$} & dois medicamentos que causam irritação gástrica (44) \\
\hline & penicilina + ácido acetilsalicílico (15) \\
\hline
\end{tabular}

* A frequiência observada de interações medicamentosas está entre parênteses.

Das 78 interações medicamentosas observadas, 94,9\% (74) foram causadas pelo cirurgião-dentista. Em 59 prescrições, o $\mathrm{CD}$ prescreveu dois medicamentos que interagem entre si. Nas 15 prescrições restantes, o CD prescreveu posteriormente à prescrição médica. Em relação a se o cirurgião perguntou ao paciente se estava utilizando outro medicamento, excluindo as 6 respostas ignoradas do questionário, 4 pacientes foram indagados pelo $\mathrm{CD}$ e 5 não foram. 


\section{Quadro 13}

Número de casos inusitados de prescrição medicamentosa, em prontuários de Unidades de Saúde de Campo Grande - MS, 2000.

\begin{tabular}{|l|c|}
\hline \multicolumn{1}{|c|}{ Caso inusitado } & $\mathbf{N}^{\mathbf{0}}$ \\
\hline Médico prescreveu para odontalgia & 5 \\
\hline $\begin{array}{l}\text { Médico prescreveu para odontalgia, após o término da medicação } \\
\text { prescrita pelo cirurgião-dentista }\end{array}$ & 1 \\
\hline $\begin{array}{l}\text { Médico modificou a prescrição odontológica, por solicitação do } \\
\text { farmacêutico da unidade. }\end{array}$ & 1 \\
\hline $\begin{array}{l}\text { Cirurgião-dentista prescreveu para saúde geral (ácido acetil } \\
\text { salicílico 100 mg para adulto) }\end{array}$ & 1 \\
\hline
\end{tabular}

Em relação ao médico ter modificado a prescrição odontológica, ocorreu o seguinte: o cirurgião-dentista prescreveu $7,5 \mathrm{ml}$ de eritromicina $250 \mathrm{mg}$ suspensão oral, o farmacêutico achou que a dose administrada estava incorreta para o paciente (criança, não foi possível identificar a idade da mesma), ao procurar o cirurgiãodentista para questionar sobre a dose, o profissional já tinha ido embora, então solicitou que o médico analisasse a prescrição, que a modificou para $2,5 \mathrm{ml}$ de eritromicina 125 mg. A correção feita pelo médico não foi correta, primeiramente, esta forma de apresentação (125 mg) não é um medicamento padronizado da SESAU, e em relação a dose, $2,5 \mathrm{ml}$ corresponde a $62,5 \mathrm{mg}$, em quatro doses diárias, totaliza $250 \mathrm{mg}$, dividindo por $30 \mathrm{mg}$ (que é a quantidade mínima por quilo de peso corporal por dia), dá 8 quilos e 300 gramas, que é o peso de uma criança de 7 a 8 meses, que tem no máximo os dentes incisivos decíduos recém-erupcionados, dificilmente apresentando algum problema bucal que fosse indicado o uso de antibióticos, além disto, questionando o farmacêutico, o mesmo não soube dizer a idade da criança, mas afirmou que não era um bebê. 


\section{DISCUSSÃo}

Das respostas dos cirurgiões-dentistas (636) sobre situações simuladas de utilização de medicamentos, correlacionando diagnóstico de enfermidades bucais e a prescrição medicamentosa, do questionário aplicado, $66,2 \%$ estavam corretas e 29,6 \% estavam incorretas. Apesar do maior percentual de acertos, este dado passa ser preocupante, pois hipoteticamente pode-se dizer que 188 pacientes teriam recebido uma prescrição inadequada, e não devem ser admitidos erros, quando colocamos em risco o estado de saúde das pessoas.

Analisando as prescrições odontológicas (509), em 78,8 \% destas, constatouse que o preenchimento estava incorreto e em $74,7 \%$, a posologia estava errada. Comparando com estudo anterior, no qual PINTO (1998), analisou 543 receitas odontológicas da rede pública de saúde de Campo Grande-MS, encontrando 60,2 \% de preenchimentos incorretos e $56 \%$ de posologias incorretas, observou-se que houve maior proporção de erros com o passar dos anos (para preenchimento $\chi^{2}=$ 42,47, $\mathrm{p}=0,000000 ;$ para posologia $\left.\chi^{2}=40,27, \mathrm{p}=0,000000\right)$.

Frente a estes resultados, surge um questionamento: por que os cirurgiõesdentistas apresentam dificuldades para prescrever medicamentos ? Alguns aspectos serão analisados a seguir.

\subsection{Anos de formado, pós-graduação e tempo de serviço do CD}

Dentre os cirurgiões-dentistas (159), a maioria possui tempo de formado $(99,4 \%)$ e de trabalho $(84,3 \%)$ superiores a cinco anos, prestando atendimento ambulatorial e plantão (66 \%). No atendimento de urgência / emergência odontológica, há maior necessidade de prescrever medicamentos quando comparado 
com o atendimento ambulatorial, pois concentra maior freqüência de pacientes com dor, inflamação e infecção.

Os dados descritos anteriormente, mostram que os cirurgiões-dentistas apresentam experiência clínica considerável, advinda da prática no serviço público, o que a princípio poderiam indicar que isto deveria propiciar maior qualidade na prescrição medicamentosa, no entanto, observou-se o seguinte: (a) não houve associação significativa entre maior número de respostas corretas referentes à utilização de medicamentos na Odontologia e as variáveis - anos de formado, $\mathrm{p}=$ 0,2492 e plantão, $p=0,3343$; (b) houve associação significativa entre maior tempo de trabalho e menor acerto das questões $(p=0,0412)$, tendo sido observadas as seguintes porcentagens de respostas corretas: menos que 5 anos $-71,9 \%$; de 5 a 15 anos $-68,7 \%$ e mais de 15 anos $-59,5 \%$.

Dos $\mathrm{CD}(\mathrm{s}), 45,3 \%$ está fazendo ou fez cursos de pós-graduação à nível de especialização, mestrado e doutorado, o que traduz em procura por aperfeiçoamento e maior conhecimento científico. Não foi encontrada associação estatisticamente significativa entre pós-graduação e maior acerto das questões sobre utilização de medicamentos na Odontologia $(p=0,1547)$.

\subsection{Conteúdo sobre farmacologia oferecido na graduação e cursos}

Uma parcela expressiva dos cirurgiões-dentistas $(63,5 \%)$ consideram deficiente o conteúdo sobre farmacologia oferecido na graduação, talvez isto justifique a procura por cursos relacionados à prescrição odontológica $(80,5 \%$ dos CDs). Não foi encontrada associação estatisticamente significativa entre as variáveis anteriormente citadas, e o número de respostas corretas e incorretas em relação à utilização de medicamentos na Odontologia (conteúdo graduação, $p=0,2352$; cursos sobre prescrição, $\mathrm{p}=0,1483$ ). 
BENITES (1999), estudou as características de prescrição dos pediatras que atuam na rede de saúde municipal de Campo Grande (MS), e observou que a aprendizagem de farmacologia pouco influi nos hábitos de prescrição do grupo estudado, havendo maior influência da propaganda de laboratórios.

Segundo CÁRDENAS e ISENRICH (1995), nas Escolas de Medicina no Peru, os cursos de farmacologia se incluem entre os estudos básicos nos primeiros anos da graduação, nos quais há o enfoque, principalmente, dos aspectos taxonômicos e descritivos dos fármacos. Nos anos clínicos, há o direcionamento para entidades nosográficas e diagnóstico, havendo pouca ênfase ao conhecimento profundo da farmacocinética, da farmacodinâmica e princípios terapêuticos. $\mathrm{O}$ resultado disto, é que o aluno no momento da prescrição, considera apenas a eficácia do medicamento, sem reparar nas possíveis reações adversas, interações etc..

Pode-se dizer que o que ocorre no Peru também acontece no Brasil. BRITTO e col. (1996), em um estudo em Faculdades de Odontologia de Belo Horizonte (MG), observaram que os alunos sentiam necessidade de mais informações sobre farmacologia básica e terapêutica clínica, principalmente quando já estavam realizando a prática odontológica com pacientes.

\subsection{Cursos recentes sobre prescrição, livros, guias, cartilhas e similares}

O cirurgião-dentista mesmo tendo recebido uma formação acadêmica para a prescrição de medicamentos na graduação, independente se foi satisfatória ou não, deveria se atualizar com freqüência, visto que surgem novos enfoques para o tratamento das doenças e também novas drogas. Neste sentido, buscou-se avaliar outras fontes de conhecimento científico.

Dentre os cirurgiões-dentistas, $82,4 \%$ recorrem a algum auxílio, como iivro, guia, cartilha, manual ou outro profissional, para prescrever medicamentos, e ainda, 
69,2 \% (110) dos CDs participaram de algum curso sobre prescrição nos últimos 12 meses (anteriores à aplicação do questionário). Foram cursos de curta duração, 71,8 $\%$ destes com carga horária máxima de 8 horas, $42,7 \%$ promovidos pela SESAU, $25,5 \%$ congressos, jornadas e similares, e $13,6 \%$ pelas entidades de classe (CRO e $\mathrm{ABO})$.

A SESAU teve maior porcentagem de indicação pelos cirurgiões-dentistas, devido ao fato de ter realizado, neste ínterim, um curso sobre atendimento odontológico para gestantes, para que o CD participasse da equipe multidisciplinar do Programa “Mãe Morena”. Neste curso, dentre outros assuntos, foi abordado a farmacologia aplicada aos diversos períodos de gestação. Não houve nenhuma referência à medicação apropriada para lactantes.

Não foi encontrada associação estatisticamente significativa entre cursos recentes e maior acerto das questões referentes à utilização de medicamentos na Odontologia ( $p=0,0789)$, isto talvez se deva ao fato de que os cursos promovem a atualização de alguns conceitos teóricos ou tendências, e não a sedimentação total do conteúdo científico exposto. A seguir estão descritos alguns resultados que podem confirmar esta observação.

O esperado é que houvesse maior porcentagem de acertos para a questão referente à utilização de medicamentos na gestante $(67,3 \%$ de respostas corretas), pela realização do curso com presença obrigatória para os cirurgiões dentistas da rede, no entanto isto não foi observado (diabético - 76,7 \%, criança - $62,9 \%$ e medicamentos contra-indicados na amamentação - 57,9\%).

Quanto ao cirurgião-dentista recorrer a algum auxílio para prescrever medicamentos, também não foi encontrada associação significativa $(p=0,8396)$ com maior acerto das questões referentes à utilização de medicamentos na Odontologia. 
Nos consultórios odontológicos das Unidades de Saúde não há a disponibilidade de guias ou similares sobre prescrição medicamentosa, então, a busca por auxílio depende da iniciativa do cirurgião-dentista, podendo ser casual.

\subsection{Guias ou similares sobre prescrição odontológica oferecidos pela}

\section{SESAU e protocolos de atendimento}

Conforme dito anteriormente, não há a disponibilidade de guias ou similares sobre prescrição medicamentosa nos consultórios odontológicos, o que foi observado foi a fixação em mural, de um protocolo de atendimento odontológico à gestante, contendo medicamentos de uso indicado e contra-indicado na gravidez, sem mencionar a posologia. Não havia referências à medicação apropriada para lactantes. Como as informações sobre farmacologia presentes no protocolo eram sucintas, não foi possível avaliar a influência deste, sobre a prescrição odontológica para gestantes.

Dentre os cirurgiões-dentistas, $41,5 \%$ responderam que a SESAU oferece algum tipo de auxílio para a prescrição odontológica, possivelmente devido a realização do curso de atendimento odontológico à gestante e a presença do protocolo de atendimento nas Unidades de Saúde.

\subsection{Prescrições odontológicas}

Da análise de 509 prescrições odontológicas, observou-se que os erros graves de preenchimento mais freqüentes foram: ausência de data $(18,1 \%)$ e ausência de identificação profissional (14,1\%). A ausência de data impossibilita ao paciente e aos demais profissionais que porventura tenham acesso à prescrição odontológica, de identificar o início e término da terapia medicamentosa. Além disto, o paciente pode apresentar a prescrição novamente, com intuito de automedicar-se. 
A não identificação do profissional na prescrição, pode eximi-lo da responsabilidade sobre o paciente. No serviço público é indispensável que se tenha o registro de qual profissional atendeu determinado paciente, para que seja avaliada a qualidade na prestação de serviços, além, é claro, dos aspectos legais desta identificação.

A falta de legibilidade parece não ser um problema nas prescrições odontológicas, visto que foi constatada em apenas $2,6 \%$.

Dentre os erros leves no preenchimento das prescrições odontológicas, em 72,3 \% o cirurgião-dentista não mencionou a quantidade necessária do medicamento ou fez de maneira incorreta. $O$ farmacêutico da unidade de saúde sempre corrige a quantidade dos medicamentos prescritos, no momento da dispensação, no entanto, em determinadas unidades de saúde onde o fluxo de pacientes é intenso, esta correção torna a dispensação mais lenta, prejudicando o andamento do serviço.

Em relação à indicação do uso do medicamento, interno ou externo, a grande maioria dos cirurgiões-dentistas faz de maneira correta, visto que estava incorreta em apenas 1,6 \% das prescrições, e ausente em 12,6\%. Das indicações incorretas observou-se como erro freqüente a indicação de "uso interno" para injetáveis.

Há boa adesão dos profissionais em relação à utilização do nome genérico dos medicamentos, apesar de 30,2 \% dos 159 cirurgiões-dentistas não conhecerem a lista de medicamentos da SESAU. A indicação pelo nome comercial ocorreu em 5,3 $\%$ das prescrições (geralmente o fármaco Penicilina $\mathrm{G}$ Benzatina, prescrito pelo nome comercial Benzetacil®), sendo também corrigida pelo farmacêutico da unidade de saúde. SANTOS (1999), em estudo sobre o fornecimento e o uso de medicamentos nos serviços de saúde do município de Ribeirão Preto (SP), observou 
que a utilização do nome comercial, ocorre predominantemente em prescrições de medicamentos injetáveis, em relação aos medicamentos utilizados por via oral .

Segundo PALMER e LISK (1997), os profissionais que trabalham no serviço público e prescrevem medicamentos genéricos, tendem a adotar esta prática também em outros serviços nos quais atuam. Isto sem dúvidas é benéfico, pois muitos cirurgiões-dentistas trabalham em outros serviços públicos ou consultórios próprios, nos quais, a prescrição de genéricos possibilita o acesso do paciente aos medicamentos disponíveis nas unidades de saúde ou diminui os custos para os adquiridos diretamente nas farmácias privadas.

Em relação à posologia das prescrições odontológicas, ocorreram os seguintes erros: tempo de administração diária (46,6 \%), geralmente indicando antibiótico de 8 em 8 horas; forma de apresentação (35,6\%), geralmente ausente; tempo total de administração $(32,2 \%)$, na maioria dos casos não mencionado e dose administrada $(31,4 \%)$, principalmente, dose incorreta para dipirona gotas e antibiótico suspensão oral.

A via de administração estava ausente em $96,1 \%$ das prescrições, e quando presente, se referiu aos medicamentos injetáveis.

De Martinez e Navarrete (1992) em estudo sobre prescrições médicas, constataram omissões em relação a via de administração, forma de apresentação (concentração do princípio ativo), tempo de administração diária, tempo total de administração e quantidade necessária do medicamento. Estas omissões foram freqüentes neste trabalho (vide Tabelas 8 e 10). 


\subsection{Medicamentos prescritos}

Em 509 prescrições, foram prescritos 771 medicamentos, isto é, em média 1,5 medicamento por prescrição odontológica, o mesmo encontrado em PINTO (1998) onde foram prescritos 811 medicamentos em 543 prescrições (mesmo universo de estudo). Considerando que a prescrição de antibiótico, em monoterapia, resolve grande parte dos problemas odontológicos (infecção), sendo coadjuvante o uso de analgésico e antiinflamatórios, esta média pode ser considerada satisfatória.

Do total de prescrições (509), observou-se os seguintes medicamentos mais prescritos: diclofenaco sódico $50 \mathrm{mg}$ comprimido (39,9\%), a ampicilina $500 \mathrm{mg}$ comprimido (37,5\%), o paracetamol $500 \mathrm{mg}$ comprimido (18,5\%) e a dipirona 500 $\mathrm{mg} / \mathrm{ml}$ gotas (15,1\%). No trabalho de PINTO (1998), do total de 543 prescrições, o medicamento mais prescrito foi a dipirona $500 \mathrm{mg} / \mathrm{ml}$ gotas $(65,8 \%$, seguido da ampicilina $500 \mathrm{mg}$ comprimido $(41,4 \%)$. O diclofenaco sódico $50 \mathrm{mg}$ comprimido foi prescrito em $10,7 \%$ e paracetamol $500 \mathrm{mg}$ comprimido em $0,18 \%$.

Comparando os trabalhos citados acima, não houve diferença estatisticamente significativa na porcentagem de prescrição de ampicilina $\left(\chi^{2}=1,68, p=0,194693\right)$, aparecendo como segundo medicamento mais prescrito em ambos. $\mathrm{O}$ que alterou do ano de 1998 para 2000 (estatisticamente significativo) foi o seguinte: a dipirona 500 $\mathrm{mg} / \mathrm{ml}$ gotas que era o medicamento mais prescrito em 1998, passa a ser o quarto $\left(\chi^{2}=277,76, p=0,000000\right) ;$ e o diclofenaco sódico $50 \mathrm{mg}$ comprimido que era o terceiro, passa a ser o mais prescrito no presente estudo $\left(\chi^{2}=120,09, p=0,000000\right)$.

Esta alteração da prescrição de um analgésico não-opióide para um antiinflamatório não-esteróide, pode revelar uma tendência na utilização deste último, que tem uso específico na Odontologia, para situações nas quais a reação inflamatória (dor e edema) estiverem causando alguma disfunção ou incapacitação 
das estruturas da boca, suplantando os benefícios de sua ocorrência (defesa do organismo). Estas situações são pouco freqüentes, mesmo em plantões odontológicos (FERREIRA e WANNMACHER 1995a).

No questionário dirigido aos pacientes, neste estudo, 7,4\% (24) dos que responderam ao questionário (324), referiram-se à inflamação como motivo da procura pelo atendimento odontológico, e 53,7\% (174) citaram a dor. É certo que este dado é subjetivo, no entanto, pode-se dizer que a necessidade de analgésicos não-opióides seria maior do que antiinflamatórios.

Por ocasião da análise das prescrições odontológicas, a dipirona $500 \mathrm{mg} / \mathrm{ml}$ gotas estava em falta em todas as farmácias das Unidades de Saúde, no entanto, poderia ter sido substituída pelo paracetamol ou pelo ácido acetilsalicílico. Foi observada menor porcentagem de prescrição de paracetamol (24,2 \%) nas prescrições odontológicas, comparando com o diclofenaco $(46,8 \%)$, considerando todas as formas de apresentação. O ácido acetilsalicílico foi prescrito em 4,1 \% das prescrições odontológicas.

CASTILHO e col. (1999), em estudo realizado a partir de questionários respondidos por 163 cirurgiões-dentistas, clínicos gerais, da região Metropolitana de Belo Horizonte, observaram que após os antimicrobianos, os antiinflamatórios nãoesteróides foi a segunda classe farmacológica mais indicada, possivelmente devido à qualidade da propaganda realizada pelos laboratórios farmacêuticos.

O antibiótico de primeira escolha coincidiu nos dois trabalhos, sendo a penicilina: em 1998, 47,2 \% de 543 prescrições odontológicas; e em 2000, 46,5 \% de 509 prescrições odontológicas (diferença estatisticamente não significativa, $\chi^{2}=$ 0,04, $p=0,849651)$. Como segunda opção, na pesquisa de PINTO (1998) foi 
utilizada a tetraciclina $(5,3 \%$ de 543 prescrições odontológicas), em 2000 , foi utilizada a cefalexina (5,7\% de 509 prescriçð̃es odontológicas).

BATTELLINO e BENNUN (1993), em estudo de emprego de medicamentos por 285 cirurgiões-dentistas, observaram também a utilização da penicilina como antibiótico de primeira escolha. Como antibiótico alternativo, nos casos de sensibilidade à penicilina, foi escolhido a eritromicina. As tetraciclinas e cefalosporinas foram as prescrições menos freqüentes.

A escolha da penicilina como primeira opção dentre os antimicrobianos é correta, visto que é relativamente não-tóxica, no entanto, a ampicilina não deveria ser a preferida, visto que é de amplo espectro, podendo não ser totalmente eficaz contra microorganismos gram-positivos (predominantes nas infecções odontológicas), neste caso seria melhor a penicilina $\mathrm{V}$ (uso oral, boa absorção), no entanto não está disponível nas unidades de saúde da SESAU.

A penicilina $\mathrm{G}$ é similar à penicilina $\mathrm{V}$ e está disponível nas unidades de saúde da SESAU, no entanto é de uso parenteral, não devendo ser prescrita simplesmente por questões de disponibilidade de medicamentos, neste caso deve haver solicitação para que a penicilina $\mathrm{V}$ seja incluída na lista de medicamentos. Segundo MONTGOMERY (1991b), a penicilina G é reservada principalmente para infecções graves, coberturas profiláticas e quando a via oral estiver comprometida (por exemplo, síndrome de má absorção e vômito).

Observou-se, neste estudo, que em todas as prescrições de penicilina de uso parenteral, foi utilizada a penicilina $G$ benzatina. De acordo com MONTGOMERY (1991b), este fármaco é inadequado para o tratamento de várias infecções agudas devido às concentrações séricas resultantes, é muito menos solúvel nos líquidos 
orgânicos e possui velocidade de absorção consideravelmente menor que a penicilina G procaína. Esta última está disponível nas unidades de saúde da SESAU.

Todos os tipos de penicilina disponíveis na lista da SESAU são sensíveis à penicilinase, que é uma enzima produzida pelos microorganismos, que inativa o antibiótico, desenvolvendo resistência às penicilinas. A resistência bacteriana pode ou não ocorrer, dependendo do tipo das bactérias envolvidas na infecção, caso ocorra, pode-se recorrer às cefalosporinas (mecanismo de ação semelhante à penicilina, ambas bactericidas), visto que não há a disponibilidade de penicilinas penicilinase-resistentes nas unidades de saúde. No presente estudo, de 509 prescrições odontológicas, a cefalosporina foi o antibiótico de segunda escolha $(5,7$ $\%)$, seguida dos seguintes antibióticos: eritromicina $(1,8 \%)$, tetraciclina $(1,2 \%)$, metronidazol $(1,2 \%)$ e clorafenicol $(0,6 \%)$.

A eritromicina é a opção quando o paciente é alérgico às penicilinas, visto que utilizando as cefalosporinas, pode haver reação de sensibilidade cruzada em pacientes sensíveis à penicilina. Tem espectro antimicrobiano similar ao da penicilina, no entanto, segundo MONTGOMERY (1991b), ocupa posição secundária por várias razões: é bacteriostática em vez de bactericida, pode haver rápido desenvolvimento de resistência à eritromicina durante o tratamento e é ligeiramente inferior às penicilinas na erradicação das infecções orodentárias.

A tetraciclina tem uso limitado, visto que é um antibiótico bacteriostático e de amplo espectro. Além disto, de acordo com MONTGOMERY (1991b), seu uso indiscriminado no passado, resultou no aparecimento de várias cepas bacterianas resistentes. É ainda utilizada para o tratamento de certas doenças periodontais, pois apresenta a vantagem de apresentar boa concentração no líquido gengival, atuando em bactérias resistentes a concentrações normalmente atingidas no plasma. 
De 509 prescrições, em 0,4 \% (2) foi observada a utilização de ácido tramexâmico injetável, que é um hemostático de uso sistêmico, que facilita a formação do coágulo, impedindo a destruição do mesmo. Esta porcentagem de utilização pode ser devido à pouca freqüência de quadros de hemorragia, o que não foi possível saber devido à ausência de dados sobre diagnóstico nas fichas de atendimento odontológico, ou também ao fato que, em presença de hemorragias após procedimentos odontológicos, medidas locais costumam ser bastante eficazes, tais como: compressão, sutura e demais técnicas hemostáticas locais (NELSON JUNIOR 1991, FERREIRA e WANNMACHER 1995c, ARMONIA e TORTAMANO 1998).

Quanto aos cirurgiões-dentistas utilizarem medicamentos que constam na lista de medicamentos da SESAU, dos 811 medicamentos prescritos em 1998, 97,7 \% constavam da lista, e em $2000,95,2 \%$. Não houve diferença estatisticamente significativa destas porcentagens $\left(\chi^{2}=6,98, p=0,008228\right)$, apesar de ter aumentado a porcentagem de cirurgiões-dentistas que conheciam a lista, de um ano para o outro, de 45,3 \% numa amostra de 53 CDs, para 69,8 \% de 159 CDs (diferença estatisticamente significativa, $\chi^{2}=10,34, p=0,001302$ ).

O fato do cirurgião-dentista conhecer ou não a lista de medicamentos da instituição, parece não influenciar a prescrição odontológica de medicamentos padronizados. Como o arsenal farmacológico utilizado na Odontologia é restrito, pode-se pensar que os profissionais que desconhecem a lista em sua totalidade, sabem da disponibilidade de alguns medicamentos padronizados, justamente os de interesse para os tratamentos odontológicos. 


\subsection{Grupos terapêuticos e forma de apresentação dos medicamentos}

Em relação aos grupos terapêuticos, não houve diferença estatisticamente significativa $\left(\chi^{2}=1,28, p=0,258661\right)$, nas porcentagens de prescrição de antibióticos, entre os estudos de PINTO 1998 (60,4\%) e 2000 (57\%), relativo ao total de prescrições, 543 e 509, respectivamente. No entanto, com o passar dos anos, aumentou a porcentagem de prescrição de antiinflamatórios não-esteróides, de 10,7 $\%$ para $46,8 \%$ (diferença estatisticamente significativa, $\chi^{2}=169,11, p=0,000000$ ); e diminui a porcentagem de prescrição de analgésico não-opióide, de 70,7 \% para 47,3 $\%$ (diferença estatisticamente significativa, $\chi^{2}=59,51, p=0,000000$ ). Quanto à tendência do aumento do uso de antiinflamatórios, já foram feitos comentários.

Dos 290 antibióticos prescritos, $6,9 \%$ (20) eram injetáveis; e dos 44 medicamentos injetáveis prescritos, 45,5\% (20) eram antibióticos injetáveis. Estes achados diferem dos encontrados por YOHKOH (1995), em estudo do atendimento odontológico em 29 escolas ou hospitais universitários no Japão, no qual observou o seguinte: dos antibióticos prescritos, $19,8 \%$ eram injetáveis e dos medicamentos injetáveis prescritos, $27 \%$ eram antibióticos.

Na posologia, o esquema "tome ... se sentir dor", ocorreu em: em 52,3 \% (126) de 241 prescrições de analgésicos não-opióides; em 2,5 \% (6) de 238 prescrições de antiinflamatório; e em 0,3 \% (1) de 290 prescrições de antibiótico. Este esquema está incorreto para os três grupos terapêuticos.

O alívio da dor é mais eficaz quando os analgésicos são dados precocemente, visto que o tratamento da dor já instalada é mais difícil, pois já foram desencadeados os mecanismos envolvidos na sensibilidade dolorosa. Os antiinflamatórios e os antibióticos são indicações específicas após avaliação profissional, . não condicionadas ao simples aparecimento de dor. 
Os antinflamatórios deverão ser utilizados quando as manifestações inflamatórias (dor, edema, trismo, limitação funcional) suplantarem o benefício da regeneração tecidual determinado pela reação inflamatória. Os antibióticos deverão ser utilizados para erradicação dos microorganismos, na presença de sinais clínicos de infecção, não se referindo às medidas sintomáticas, embora os sinais e sintomas desapareçam com o extermínio das bactérias, visto que cessa a produção de componentes bacterianos, geradores de reação inflamatória.

\subsection{Tipo de prescrição}

Os tipos de prescrição mais freqüentes, em relação ao total de 509 prescrições, foram: somente antibiótico $(19,8 \%)$, somente antiinflamatório nãoesteróide (16,9\%), analgésico não-opióide + antibiótico $(16,1 \%)$, antiinflamatório não-esteróide + antibiótico (15,7\%), somente analgésico não-opióide (15,1\%), e analgésico não-opióide + antiinflamatório não-esteróide $(10,8 \%)$. No estudo de PINTO (1998), do total de prescrições (543), observou-se os seguintes tipos de prescrição mais freqüentes: analgésico típico (não-opióide) + antibiótico $(30,8 \%)$, somente analgésico típico $(27,4 \%)$ e somente antibiótico (19 \%). A alteração do padrão de prescrição, voltada para o uso de antiinflamatórios, já foi comentada anteriormente.

Ocorreram outros tipos de prescrição odontológica, que apesar de pouco freqüentes, merecem alguns comentários, tais como: associação de antibióticos; o mesmo medicamento (antibiótico, antiinflamatório ou analgésico) por vias distintas (oral e parenteral); e associação de analgésicos não-opióides.

Foi observada a associação de antibiótico (ampicilina ou tetraciclina) com metronidazol, em 5 prescrições. A associação de tetraciclina e metronidazol está incorreta, pois poderá haver redução do efeito do metronidazol (bactericida), na 
presença de tetraciclina (bacteriostática). O metronidazol pode ser associado à ampicilina, para tratamento de infecções com predomínio de bactérias anaeróbias, em certas doenças periodontais, tais como: periodontite pré-puberal, periodontite juvenil localizada e periodontite do adulto refratária (RÖSING 1995).

Segundo FERREIRA e WANNMACHER (1995b), os antibióticos geralmente devem ser empregados em monoterapia, pois são bastante eficazes quando a indicação é adequada, coerente com a especificidade dos mesmos. A associação deve ser empregada em situações de necessidade de maior espectro de sensibilidade e eficácia antimicrobiana, ou para limitar a emergência de resistência bacteriana, visto que, acarretam maior custo e maior possibilidade de efeitos adversos.

$\mathrm{Na}$ administração do mesmo medicamento por vias distintas (oral e parenteral), pode haver o risco do paciente ingerir doses excessivas das drogas, podendo ocorrer efeitos tóxicos. Mesmo se o profissional explicar bem como se deve utilizar os medicamentos, o paciente pode se confundir ou mesmo propositadamente utilizar todos os medicamentos ao mesmo tempo, com intuito de minimizar mais rapidamente algum sintoma. Se não há algum impedimento da utilização por via oral, é preferível optar primeiramente por esta via, pedindo ao paciente que retorne, caso os sintomas não desapareçam, ou então, optar diretamente pela via parenteral, em presença de quadro agudo grave.

Em 2 prescrições, o cirurgião-dentista prescreveu ampicilina comprimido + penicilina injetável, para uso concomitante, havendo portanto uma dose excessiva do medicamento, ainda bem que a penicilina é um antibiótico relativamente atóxico. $\mathrm{O}$ farmacêutico da Unidade foi consultado sobre estes casos, tendo relatado que já havia procurado o cirurgião-dentista para conversar a respeito, no entanto o 
profissional acha correto este tipo de prescrição, não tendo sido feita qualquer correção nas prescrições. Em 3 prescrições, o cirurgião-dentista prescreveu diclofenaco via oral e diclofenaco injetável.

Em relação à associação de analgésicos não-opióides, observou-se: dipirona injetável + paracetamol via oral (certamente pela falta de dipirona via oral), Ácido acetilsalicílico + paracetamol, Ácido acetilsalicílico + dipirona e três analgésicos não-opióides, dipirona injetável + dipirona gotas + paracetamol. Nas prescrições em questão não havia nenhuma orientação, por escrito, se referindo ao uso concomitante ou não, e não foi possível nestes casos, identificar o profissional que procedeu a dispensação, para indagar a respeito.

De acordo com Furst e col. (1987) citado por WANNMACHER e FERREIRA (1995e, p. 93), não está indicada a associação de dois ou mais analgésicos nãoopióides, pois há evidências de que competem entre si pela ligação a proteínas plasmáticas, aumentando a velocidade de depuração daquele que permanece na forma não-conjugada. Segundo Ciancio 1989 citado por WANNMACHER e FERREIRA (1995e, p. 93), não há afeito analgésico adicional com esta associação, podendo aumentar a ocorrência de efeitos adversos gastrintestinais e renais.

\subsection{Anamnese}

Um dos requisitos básicos para assegurar a qualidade de qualquer prescrição, é conhecer a história clínica do paciente, isto é, realizar a anamnese completa. A princípio, nas Unidades de Saúde da SESAU, há duas formas do cirurgião-dentista obter tais informações: acessando o prontuário do paciente e perguntando diretamente para o mesmo.

Dos 324 pacientes que preencheram o questionário sobre a consulta odontológica, 63,9 \% (207) responderam que o cirurgião-dentista não perguntou 
sobre se tinham algum problema de saúde, $65,1 \%$ (211) não foram indagados se passavam mal ao utilizar algum medicamento e $67,6 \%$ (219) não foram questionados se estavam utilizando algum outro medicamento. De 220 pacientes do sexo feminino, $41,4 \%(91)$ do total não foram indagadas se estavam grávidas ou amamentando.

Dos 20 pacientes para os quais foi prescrito penicilina injetável, para 12 foi solicitada a realização do teste de sensibilidade, destes 12 pacientes, excetuando 5 que não responderam ao questionário, apenas 2 foram questionados pelo cirurgiãodentista, se passavam mal utilizando algum medicamento. Há consenso na literatura, que os testes de sensibilidade à penicilina tem valor limitado (vide comentários no capítulo da introdução), e que o procedimento correto consiste em perguntar ao paciente se ele já apresentou alguma reação com a utilização do referido antibiótico. Pode-se dizer que há deficiências na atualização do conhecimento científico destes profissionais, além da negligência em relação à realização da anamnese.

Observou-se então, que mais ou menos dois terços dos pacientes não foram submetidos à anamnese pelos cirurgiões-dentistas da SESAU. Isto demonstra que estes profissionais não procuram obter dos pacientes, informações básicas sobre o estado de saúde, de modo a dar subsídios para que se tenha um prescrição medicamentosa adequada, no entanto, costumam explicar sobre como utilizar os medicamentos prescritos; $81,5 \%$ dos pacientes responderam que receberam tais explicações do cirurgião-dentista.

Diante do fato da anamnese não ser um procedimento freqüente, será que há disponibilidade de dados sobre a saúde geral do paciente do prontuário médico da Unidade de Saúde ? Dos 159 cirurgiões-dentistas que responderam a respeito, 67,3 \% (107) disseram ter dificuldades para acessar o prontuário do paciente. O cirurgião- 
dentista tem que solicitar a impressão do prontuário completo do paciente, entretanto, pode ocorrer da auxiliar não saber acessá-lo, ou de não haver tempo hábil para isto, visto que são impressos todos os atendimentos, desde a primeira vez que o paciente procurou a Unidade de Saúde. Caso o paciente nunca tenha procurado atendimento em nenhuma Unidade de Saúde da SESAU, não teriam dados disponíveis.

Mesmo que houvesse maior disponibilidade do prontuário do paciente, há limitações na qualidade e quantidade dos dados registrados. São encontradas informações em relação aos procedimentos realizados nos atendimentos e solicitação de exames complementares, dificilmente é encontrado o diagnóstico, às vezes há a indicação do CID - Código Internacional de Doenças (ORGANIZAÇÃO MUNDIAL DA SAÚDE 1993b), no entanto, os cirurgiões-dentistas não saberiam os códigos, sem um guia ou livro. Não tem dados da história clínica, nem mesmo um questionário sobre a condição de saúde do paciente. A terapêutica medicamentosa, freqüentemente, não é registrada, ou é mencionada como "sintomática". Esta deficiência dos prontuários médicos, da rede municipal de saúde de Campo Grande / MS, foi relatada em outros trabalhos: ISHIKAWA (1997) e CUNHA (1999).

$\mathrm{Na}$ odontologia a escassez de dados é nítida, neste estudo, não foram encontrados dados referentes ao diagnóstico ou terapêutica medicamentosa prescrita, nos prontuários analisados via computador.

Dos 159 cirurgiões-dentistas, $50,3 \%$ (80) responderam no questionário aplicado, que: não há prontuário ou ficha clínica própria e adequada para fazer anotações; não há campo específico no registro informatizado de dados da SESAU, mesmo se anotar na ficha de atendimento, não sabe se as informações são digitadas; e que, no serviço público, não há preocupação com isto, apenas com o número de 
pacientes atendidos (não há orientações da Coordenação Odontológica), não faz parte da rotina (escassez de tempo), falta de costume e negligência.

Dos cirurgiões-dentistas que responderam que fazem o registro do diagnóstico e medicamentos prescritos, correspondendo a 46,5\% dos $\operatorname{CD}(\mathrm{s})(74)$, disseram que o fazem no atendimento ambulatorial, utilizando fichas clínicas, não havendo digitação posterior, e que no plantão não é possível, pois há apenas o registro dos procedimentos, via computador.

No entanto, na ficha de atendimento odontológico, que posteriormente é digitada, há um campo disponível, chamado de "Observações de Diagnósticos" (Anexo 6), para o profissional fazer as anotações que julgar necessárias. Há portanto um local para o registro de dados, que parece ser subutilizado pelos cirurgiõesdentistas. Quanto à suspeita que as informações podem não ser digitadas posteriormente, isto não ocorreria mais, devido ao fato que, atualmente, os próprios profissionais digitam as fichas de atendimento no final do turno.

CASTILHO e col. (1999), em estudo realizado a partir de questionários respondidos por 163 cirurgiões-dentistas, clínicos gerais, da região Metropolitana de Belo Horizonte, observaram que $43 \%$ destes não registravam as prescrições medicamentosas nas fichas clínicas de seus pacientes.

\subsection{Pacientes especiais}

A qualidade das informações sobre o estado de saúde dos pacientes é imprescindível, visto que o profissional pode estar prescrevendo algum medicamento inadequado para pacientes portadores de alguma enfermidade ou em situações fisiológicas / anatômicas específicas (pacientes especiais), como a gravidez e amamentação, crianças, idosos, ou uso contínuo de certos medicamentos. 
Os pacientes considerados especiais, totalizaram $31,6 \%$ (161) dos atendimentos efetuados (509) nos quais houve prescrição medicamentosa, no período de um mês (período de estudo proposto), nas Unidades de Saúde que oferecem atendimento odontológico 24 horas. Este percentual pode estar subestimado, devido às limitações do registro de dados nos prontuários, citadas anteriormente. Destes 161 pacientes, para 46,6 \% (75) foram feitas indicações medicamentosas inadequadas.

Foram observadas indicações de medicamentos inadequadas, principalmente com o uso de diclofenaco, em: hipertensos, pacientes com distúrbios gástricos, gestantes, diabéticos e asmáticos.

De acordo com Fuchs (1992) citado por FERREIRA e WANNMACHER (1995d, p. 201), os pacientes com doença cardiovascular tratados com diuréticos, bloqueadores alfa-adrenérgicos e inibidores da convertase, o efeito anti-hipertensivo é prejudicado pelo uso de antiinflamatórios não-esteróides (diclofenaco, ácido acetilsalicílico)

Em pacientes com distúrbios gástricos, os antiinflamatórios não-esteróides e os analgésicos não-opióides (paracetamol e ácido acetilsalicílico) são contraindicados, por seu efeitos inibidores da proteção gástrica (FERREIRA e WANNMACHER 1995d).

Nos pacientes diabéticos, o uso de antiinflamatórios não-esteróides (diclofenaco, ácido acetilsalicílico) e esteróides aumenta a glicemia. Dez por cento dos adultos com asma brônquica podem ter a doença precipitada por aspirina e os demais antiinflamatórios não-esteróides (FERREIRA e WANNMACHER 1995d).

$\mathrm{Na}$ gravidez, os antiinflamatórios não-esteróides devem ser evitados, pois podem provocar hipertensão pulmonar no feto (Secretaria Municipal de Saúde de Vitória 1998). É contra-indicada a tetraciclina para gestantes, pois causa deficiência 
na formação do esmalte dentário, coloração anormal dos dentes e retardo do crescimento ósseo na criança. A eritromicina não deve ser utilizada por lactantes, quando o lactente está com menos de um mês de idade, pois pode provocar icterícia (WANNMACHER e FERREIRA 1995g).

De 67 prescrições odontológicas para crianças, em 50,7 \% (34) ocorreu à indicação de diclofenaco. Este fármaco não é aprovado para uso infantil nos Estados Unidos (PITREZ 1995).

No questionário aplicado aos cirurgiões-dentistas (159), 71,7\% dos $\mathrm{CD}(\mathrm{s})$ (114) responderam que pedem autorização médica para utilizar medicamentos em paciente com algum problema de saúde, quando necessário a depender do quadro do paciente, com propósito de dividir responsabilidades, no entanto, mais no sentido de troca de idéias com o médico, dado que este profissional pode ter mais informações sobre o estado de saúde do paciente. Esta posição de troca de idéias com o médico é bastante positiva, e o cirurgião-dentista deve estar seguro dos seus conhecimentos sobre farmacologia, para poder argumentar.

Quanto a pedir autorização médica para utilização de medicamentos em grávidas ou lactantes, $25,8 \%$ dos $\mathrm{CD}(\mathrm{s})$ (41) pedem quando a gestante apresenta algum problema de saúde (recomendação da SESAU no protocolo de atendimento) e $35,8 \%$ (57) $\mathrm{CD}(\mathrm{s})$ pedem dependendo do período gestacional, visto que consideram difícil a prescrição até o $3^{\circ}$ mês e também quando há algum problema de saúde. Dentre os que nunca pedem (17), $2 \mathrm{CD}(\mathrm{s})$ acham que os medicamentos prescritos na Odontologia não interferem no feto ou na mãe. Vale ressaltar as indicações de medicamentos inadequadas, citadas anteriormente, para grávidas e lactantes.

E quando há emissão de autorização por escrito do médico, relacionada à prescrição de medicamentos para pacientes com problemas de saúde, grávidas ou 
lactantes, observou-se neste estudo o seguinte: $57,2 \%$ dos cirurgiões-dentistas (91) voltam a questionar o médico, se não concordam com alguma orientação, no entanto, $37,8 \%$ (60) sempre seguem independentemente se concordam ou não, visto que consideram muito difícil a troca de idéias com aquele profissional, e que jamais o paciente concordará com o $\mathrm{CD}$ e discordará do médico. Se o cirurgião-dentista se sentir inseguro e sem confiança nos próprios conhecimentos, será muito difícil argumentar com o médico e paciente.

\subsection{Prescrições coincidentes}

No atendimento nas Unidades de Saúde, freqüentemente, os pacientes consultam com mais de um profissional no mesmo dia, ou num curto período de tempo. Geralmente, são prescritos medicamentos nos diversos atendimentos, podendo ocorrer as prescrições coincidentes, isto é, prescrição do mesmo medicamento para tratar o mesmo problema ou não, ou prescrição de medicamentos distintos, para tratar o mesmo problema. Não há controle na farmácia da Unidade, e o paciente recebe todos os medicamentos que constarem nas diversas prescrições.

Do total de 509 pacientes atendidos, 1,4 \% (7) tiveram prescrições coincidentes, sendo que destas 7 coincidências, 4 ocorreram em atendimentos médicos e odontológicos efetuados no mesmo dia. Apesar deste percentual estar subestimado, devido a deficiências nos prontuários médicos, este é um problema sério, que pode estar oculto para as instituições. Além do gasto desnecessário com a dispensação de excesso de medicamentos, o paciente pode ter a saúde prejudicada pelo uso de doses elevadas dos mesmos, por reações adversas ou por interações medicamentosas.

VICENTE e col. (1999), a partir da análise de prontuários de menores de 12 anos de idade internados no Hospital Universitário / UFMS, no período de 1990 a 
1997, observaram maior ocorrência de reações adversas com o uso de antiinfecciosos, devido à utilização em larga escala. Consideram, portanto, indispensável a implantação de um programa de vigilância de reações adversas de medicamentos nas unidades de saúde.

\subsection{Interações medicamentosas}

Os tipos de interação mais observados foram: (a) dois medicamentos que causam irritação gástrica, penicilina + ácido acetilsalicílico e (b) antibiótico + anticoncepcional, causando a perda do efeito deste último. Das 509 prescrições odontológicas analisadas, em 11,6 \% (59), o cirurgião-dentista prescreveu dois medicamentos que interagem entre si; em $3 \%$ (15), a prescrição do CD foi posterior a do médico, causando a interação medicamentosa e em $0,4 \%$ (2), médico e cirurgião-dentista prescreveram no mesmo dia, ocorrendo a interação medicamentosa.

Segundo MEDAL e col. (1993), uma medida que pode ser tomada para evitar a interação medicamentosa, quando o profissional desconhece se o paciente já está utilizando outro medicamento, é a utilização de uma tarjeta de notificação, na qual conste: quais medicamentos está tomando e quanto. $\mathrm{O}$ impresso deveria ser entregue ao profissional em cada atendimento diferente.

Este procedimento confere maior confiabilidade nas informações, visto que na anamnese, o paciente pode não recordar todos os detalhes em relação à terapêutica medicamentosa a qual está sendo submetido. Como a SESAU dispõe de sistema informatizado de prontuários, esta notificação poderia ser impressa junto com as fichas de atendimento, no momento da consulta, evitando assim as prescrições coincidentes e as interações medicamentosas. 


\subsection{Prescrições inusitadas}

Outros fatos observados, merecem comentários mais pelo aspecto qualitativo, que pelo quantitativo, são eles: (a) médico prescrevendo em caso de odontalgia; (b) médico modificando a prescrição do cirurgião-dentista (não estava mais na Unidade de Saúde), por solicitação do farmacêutico e (c) cirurgião-dentista prescrevendo para outro problema de saúde geral (medicamento de uso crônico).

Os profissionais têm que buscar um trabalho integrado, entretanto, não podem atuar em áreas que não são de sua competência. Vale ressaltar que, se o cirurgiãodentista e o médico prescreverem algum medicamento que não seja de uso odontológico e médico, respectivamente, estarão cometendo uma infração penal (exercício ilegal de profissão), prevista no Código Penal Brasileiro (Art. 282), constituindo também, em infração ética, nos respectivos Códigos de Ética em vigor (CARDOZO e CALVIELLI 1988, RAMOS e col. 1995). 


\section{CONCLUSÕES}

\subsection{Conclusões}

Foram estudadas algumas variáveis em relação aos cirurgiões-dentistas que atuam nas Unidades de Saúde de Campo Grande - MS, destacando aspectos relacionados com a prescrição odontológica e indicação do uso de medicamentos da clientela que os demanda, e os resultados obtidos, permitem as seguintes conclusões:

- Dentre os cirurgiões-dentistas (159), a maioria possui tempo de formado (99,4 \%) e de trabalho $(84,3 \%)$ superiores a cinco anos, desenvolvendo atendimento ambulatorial e plantão (66 \%). Não foi encontrada associação significativa entre número de respostas corretas e incorretas referentes à utilização de medicamentos na Odontologia e as variáveis - anos de formado e plantão. Houve associação significativa entre maior tempo de trabalho e menor acerto das questões (menos que 5 anos $-71,9 \%$; de 5 a 15 anos $-68,7 \%$ e mais de 15 anos $-59,5 \%$ ).

- Dos $159 \mathrm{CD}(\mathrm{s}), 45,3 \%$ está fazendo ou fez cursos de pós-graduação à nível de especialização, mestrado e doutorado. Não foi encontrada associação estatisticamente significativa entre fazer pós-graduação e ter maior acerto das questões sobre utilização de medicamentos na Odontologia.

- Uma parcela expressiva dos cirurgiões-dentistas $(63,5 \%)$ consideram deficiente o conteúdo sobre farmacologia oferecido na graduação, talvez isto justifique a procura por cursos relacionados à prescrição odontológica $(80,5 \%$ dos CDs). Não foi encontrada associação estatisticamente significativa entre as variáveis anteriormente citadas, e o número de respostas corretas e incorretas em relação à utilização de medicamentos na Odontologia. 
- Dentre os cirurgiões-dentistas, $82,4 \%$ recorrem a algum auxílio, como livro, guia, cartilha, manual ou outro profissional, para prescrever medicamentos. Não foi encontrada associação significativa com maior acerto das questões referentes à utilização de medicamentos na Odontologia.

- Dos $159 \mathrm{CD}(\mathrm{s}), 69,2 \%$ dos CDs participaram de algum curso sobre prescrição nos últimos 12 meses (anteriores à aplicação do questionário). Não foi encontrada associação estatisticamente significativa entre cursos recentes e maior acerto das questões referentes à utilização de medicamentos na Odontologia.

- Dentre os cirurgiões-dentistas (159), 41,5\% responderam que a SESAU oferece algum tipo de auxílio para a prescrição odontológica.

- Nas situações simuladas de utilização de medicamentos (636), correlacionando o diagnóstico de enfermidades bucais e a prescrição medicamentosa, do questionário aplicado, $66,2 \%$ estavam corretas e $29,6 \%$ estavam incorretas.

- Através da análise das prescrições odontológicas (509), em 78,8 \% destas, constatou-se que o preenchimento estava incorreto e em $74,7 \%$, a posologia estava errada. Concluiu-se um aumento da proporção de erros de 1998 a 2000 (para preenchimento $\chi^{2}=42,47, \mathrm{p}=0,000000$; para posologia $\chi^{2}=40,27, \mathrm{p}=0,000000$ ).

- Dos erros graves de preenchimento, os mais freqüentes foram: ausência de data $(18,1 \%)$ e ausência de identificação profissional $(14,1 \%)$.

- Dentre os erros leves no preenchimento das prescrições odontológicas, em $72,3 \%$ o cirurgião-dentista não mencionou a quantidade necessária do medicamento ou fez de maneira incorreta. Em relação à indicação do uso do medicamento, intermo ou externo, a grande maioria dos cirurgiões-dentistas faz de maneira correta, visto que 
estava incorreta em apenas $1,6 \%$ das prescrições, e ausente em 12,6\%. Das indicações incorretas observou-se como erro freqüente a indicação de "uso interno" para injetáveis.

- Há boa adesão dos profissionais em relação à utilização do nome genérico dos medicamentos, apesar de $30,2 \%$ dos cirurgiões-dentistas não conhecerem a lista de medicamentos da SESAU.

- Em relação à posologia das prescrições odontológicas, ocorreram os seguintes erros: tempo de administração diária (46,6 \%), geralmente indicando antibiótico de 8 em 8 horas; forma de apresentação (35,6 \%), geralmente ausente; tempo total de administração (32,2\%), na maioria dos casos não mencionado e dose administrada $(31,4 \%)$, principalmente, dose incorreta para dipirona gotas e antibiótico suspensão oral.

- A via de administração estava ausente em $96,1 \%$ das prescrições, e quando presente, se referiu aos medicamentos injetáveis.

- A média de medicamento por prescrição odontológica foi de 1,5 , considerando que a prescrição de antibiótico, em monoterapia, resolve grande parte dos problemas odontológicos (infecção), sendo coadjuvante o uso de analgésico e antiinflamatórios, este valor pode ser considerado satisfatório.

- O diclofenaco sódico $50 \mathrm{mg}$ comprimido $(39,9 \%)$ foi o medicamento mais prescrito. $\mathrm{O}$ antibiótico de primeira escolha foi a penicilina.

- Observou-se, neste estudo, que em todas as prescrições de penicilina de uso parenteral, foi utilizada a penicilina $\mathrm{G}$ benzatina.

- Todos os tipos de penicilina disponíveis na lista da SESAU são sensíveis à penicilinase. 
- Dos 771 medicamentos prescritos, $95,2 \%$ constavam da lista de medicamentos da SESAU. O fato do cirurgião-dentista conhecer ou não a lista de medicamentos da instituição, parece não influenciar a prescrição odontológica de medicamentos padronizados.

- Em relação aos grupos terapêuticos, de 1998 a 2000, aumentou a porcentagem de prescrição de antiinflamatórios não-esteróides, de 10,7\% para 46,8 \% e diminui a porcentagem de prescrição de analgésico não-opióide, de 70,7 \% para 47,3 \%.

- Dos 290 antibióticos prescritos, 6,9\% eram injetáveis; e dos 44 medicamentos injetáveis prescritos, $45,5 \%$ eram antibióticos injetáveis.

- Na posologia, o esquema "tome ... se sentir dor", ocorreu para analgésicos nãoopióides, antiinflamatórios e antibióticos.

- Os tipos de prescrição mais freqüentes foram: somente antibiótico (19,8\%), somente antiinflamatório não-esteróide (16,9 \%), analgésico não-opióide + antibiótico (16,1\%), antiinflamatório não-esteróide + antibiótico $(15,7 \%)$, somente analgésico não-opióide $(15,1 \%)$, e analgésico não-opióide + antiinflamatório nãoesteróide $(10,8 \%)$. Pode-se perceber o uso de antiinflamatórios como padrão de prescrição.

- Ocorreram outros tipos de prescrição odontológica, tais como: associação de antibióticos; o mesmo medicamento (antibiótico, antiinflamatório ou analgésico) por vias distintas (oral e parenteral); e associação de analgésicos não-opióides.

- Dos 324 questionários respondidos pelos pacientes: 7,4\% referiram-se à inflamação como motivo da procura pelo atendimento odontológico, e 53,7 \% citaram a dor; $63,9 \%$ responderam que o cirurgião-dentista não perguntou sobre se tinham algum problema de saúde; $65,1 \%$ não foram indagados se passavam mal ao 
utilizar algum medicamento e $67,6 \%$ não foram questionados se estavam utilizando algum outro medicamento. De 220 pacientes do sexo feminino, $41,4 \%$ do total não foram indagadas se estavam grávidas ou amamentando.

- Há limitações na qualidade e quantidade dos dados registrados nos prontuários dos pacientes. São encontradas informações em relação aos procedimentos realizados nos atendimentos e solicitação de exames complementares, dificilmente é encontrado o diagnóstico, às vezes há a indicação do CID - Código Internacional de Doenças (é dificil saber os códigos, sem um guia ou livro).

- Dentre os cirurgiões-dentistas, $46,5 \%$ responderam que fazem o registro do diagnóstico e medicamentos prescritos.

- Os pacientes considerados especiais, totalizaram 31,6\% (161) dos atendimentos efetuados (509) nos quais houve prescrição medicamentosa, no período de um mês (período de estudo proposto), nas Unidades de Saúde que oferecem atendimento odontológico 24 horas. Destes 161 pacientes, para 46,6 \% foram feitas indicações medicamentosas inadequadas, principalmente o uso de diclofenaco em: hipertensos, pacientes com distúrbios gástricos, gestantes, diabéticos e asmáticos.

- De 67 prescrições odontológicas para crianças, em 50,7 \% ocorreu a indicação de diclofenaco.

- No questionário aplicado aos cirurgiões-dentistas (159), 71,7 \% dos CD(s) responderam que pedem autorização médica para utilizar medicamentos em paciente com algum problema de saúde, quando necessário a depender do quadro do paciente, com propósito de dividir responsabilidades, no entanto, mais no sentido de troca de idéias com o médico, dado que este profissional pode ter mais informações snbre o estado de saúde do paciente. 
- Quanto a pedir autorização médica para utilização de medicamentos em grávidas ou lactantes, $25,8 \%$ dos $\mathrm{CD}(\mathrm{s})$ (41) pedem quando a gestante apresenta algum problema de saúde (recomendação da SESAU no protocolo de atendimento) e 35,8 \% (57) $\mathrm{CD}(\mathrm{s})$ pedem dependendo do período gestacional, visto que consideram dificil a prescrição até o $3^{\circ}$ mês e também quando há algum problema de saúde. Dentre os que nunca pedem (17), $2 \mathrm{CD}(\mathrm{s})$ acham que os medicamentos prescritos na Odontologia não interferem no feto ou na mãe.

- E quando há emissão de autorização por escrito do médico, relacionada à prescrição de medicamentos para pacientes com problemas de saúde, grávidas ou lactantes, observou-se neste estudo o seguinte: $57,2 \%$ dos cirurgiões-dentistas voltam a questionar o médico, se não concordam com alguma orientação, no entanto, $37,8 \%$ sempre seguem independentemente se concordam ou não, visto que consideram muito difícil a troca de idéias com o médico, e que jamais o paciente concordará com o CD e discordará do médico.

- Do total de 509 pacientes atendidos, 1,4\% tiveram prescrições coincidentes, isto é, prescrição do mesmo medicamento para tratar o mesmo problema ou não, ou prescrição de medicamentos distintos, para tratar o mesmo problema. Isto ocorreu com analgésico não-opióide (dipirona, paracetamol), antiinflamatório não-esteróide (diclofenaco) e antibiótico (ampicilina, cefalexina).

- Os tipos de interação medicamentosa mais observados foram: (a) dois medicamentos que causam irritação gástrica, penicilina + ácido acetilsalicílico e (b) antibiótico + anticoncepcional, causando a perda do efeito deste último. Das 509 prescrições odontológicas analisadas, em 11,6 \%, o cirurgião-dentista prescreveu dois medicamentos que interagem entre si; em $3 \%$, a prescrição do CD foi posterior 
a do médico, causando a interação medicamentosa e em $0,4 \%$, médico e cirurgiãodentista prescreveram no mesmo dia, ocorrendo a interação medicamentosa.

\subsection{Sugestð̃es}

Levando em conta que ações esporádicas podem não surtir os efeitos esperados na melhoria da qualidade da prescrição medicamentosa, há a necessidade da implantação de um programa de monitoramento, no qual possam ser utilizados dados sobre avaliações de prescrições medicamentosas, para que os profissionais utilizem os medicamentos de maneira racional, no serviço público (EDWARDS e HUGMAN 1997, GILL e col. 1999, DE VRIES 1999a 1999b).

Os autores, BATTY e BARBER 1992, ARA e MARCHAND 1995, LINARES e col. 1995, WILLISON e col. 1995, MADRID e col. 1998, CASTRO 2000, abordam sobre as ações possíveis de serem implementadas no serviço público, a fim de melhorar a qualidade da prescrição de medicamentos; tendo como base esta literatura, sugere-se as seguintes:

- realização de cursos periódicos sobre farmacologia aplicada à Odontologia, para cirurgiões-dentistas e farmacêuticos das Unidades de Saúde;

- formação de grupos de leitura e discussão, com os profissionais das Unidades de Saúde, que estiverem envolvidos direta ou indiretamente com a prescrição medicamentosa. A periodicidade desta atividade poderá ser determinada, de modo a não interferir na rotina da Unidade de Saúde;

- envio de comunicados internos, com o objetivo de alertar os profissionais, em relação à prescrição de medicamentos que não são de suas competências, visto que se trata de infração ética e penal. Os profissionais têm que buscar um trabalho integrado, e um bom momento para discutir isto, poderia ser nos grupos de leitura sugeridos anteriormente; 
- reformulação da lista de medicamentos básicos, com a inclusão de outros medicamentos apropriados à prática odontológica;

- distribuição de guias ou manuais terapêuticos para os cirurgiões-dentistas, contendo os medicamentos padronizados da SESAU, explicações básicas sobre as patologias odontológicas, informações sobre preenchimento das prescrições medicamentosas e posologias adequadas, levando em conta o diagnóstico, condições especiais de saúde e idade;

- adoção de protocolos de atendimento, contendo normatizações em relação ao atendimento odontológico de pacientes especiais;

- implantação de um questionário único para a anamnese, acompanhando a ficha de atendimento odontológico, tanto no plantão como no ambulatório, sendo preenchido obrigatoriamente na primeira consulta e posteriormente complementado a cada atendimento;

- implantação de tarjeta de notificação, também acompanhando a ficha de atendimento odontológico, contendo medicamentos que o paciente está tomando e posologia, provenientes de consultas médicas e odontológicas;

- normatização do registro de dados, de modo a fornecer informações em relação ao diagnóstico e terapêutica empregada nos atendimentos odontológicos;

- formação de um comitê, a nível central, com o objetivo de: realizar estudos de utilização de medicamentos (EUMs), preconizados pela OMS; elaborar normas uniformes de tratamento medicamentoso; e avaliar os efeitos das intervenções nas prescrições (monitoramento qualitativo e quantitativo de prescrições odontológicas, registro de incidentes, uso de visitadores e conselheiros farmacológicos nas Unidades de Saúde, entrevista com os pacientes etc.); 
- distribuição de folhetos para os pacientes, abordando assuntos, como por exemplo: automedicação na odontologia, riscos da endocardite bacteriana, cuidados odontológicos com o bebê e gestante etc.. 


\section{REFERÊNCIAS}

Abreu CM, Flores GAL, Martins PG, Salvi RM. Risco do uso de medicamentos no período da lactação: estudo farmacocinético em populações especiais. Infarma 1996; $5(1 / 4): 12-5$.

Amaral JS, Neves ILI, Ribeiro PM, Vasconcellos MCC. Conduta clínica de cirurgiões-dentistas frente ao cardiopata. Rev Odontol Univ São Paulo 1994; 8 (4): $287-92$.

Ara A, Marchand B. Buscando remedio: atención básica y uso de medicamentos esenciales. Guía de aprendizaje y acción para el trabajador de Salud a nivel local. Nicaragua: Acción Internacional por la Salud; 1995.

Arbenz GO. Medicina legal e antropologia forense. Rio de Janeiro: Atheneu; 1988.

Armonia PL, Tortamano N. Como prescrever em Odontologia. $5^{a}$ ed. São Paulo: Editora Santos; 1998.

Battellino LJ, Bennun FR. Nivel de información y conducta farmacoterapéutica de los odontólogos, 1990. Rev Saúde Pública 1993; 27 (4): 291-9.

Batty R, Barber N. Ward pharmacy: a foundation for prescribing audit ? Quality in health care $1992 ; 4: 5-9$.

Benites ST. Características de prescrição dos pediatras que atuam na rede de Saúde Municipal de Campo Grande / MS. Saúde Farmacológica 1999 jul: 15-6. 
Bernaba JM. Aspectos legais e instrucionais, relativos à prescrição de medicamentos e substâncias equiparados a entorpecentes e colaterais, no campo odontológico. Rev Ass paul Cirurg Dent 1982; 36 (5): 540-6.

Britto TA de, Castilho LS de, Paixão HH. Os estudantes de odontologia e a (in)segurança para prescrever medicamentos. Arq Centro Estud Curso Odontol 1996; $32(1): 51-64$

Canto Pereira LHM do, Paula Ramos DL de, Crosato E. Ansiedade e dor em Odontologia - enfoque psicofisiopatológico. Revista da APCD 1995; 49 (4): 28590.

Cárdenas EZ, Isenrich LL. Hábitos de prescripción de los médicos peruanos y fatores que influyen en ellos. Bol Oficina Sanit Panam 1995; 118 (6): 479-87.

Cardozo HF, Calvielli ITP. Considerações sobre as receitas odontológicas. Odontólogo Moderno 1988; 15 (8): 20-3.

Carneiro CAN, Castro LLC de. Contribution to the rational use of drugs: study of the level of knowledge of physicians, pharmacists, nurses and administrators about the various aspects involved in the use of drugs in the hospitals of Campo Grande, MS Brasil. Pharmacoepidemiology and Drug Safety 1998; 7 (2): S 181.

Castilho LS, Paixão HH, Perini E. Prescrição de medicamentos de uso sistêmico por cirurgiões-dentistas, clínicos gerais. Rev Saúde Pública 1999; 33 (3): 287-94.

Castro LLC de. Farmacoepidemiologia no Brasil: evolução e perspectivas. Ciência \& Saúde Coletiva 1999; 4 (2): 405-9. 
Castro LLC de, organizador. Fundamentos de Farmacoepidemiologia. Campo Grande (MS): Grupo de Pesquisa em Uso Racional de Medicamentos (GRUPURAM); 2000. Farmacoepidemiologia: uma nova disciplina; p. 5-18.

Castro LLC de, Costa AM, Kozoroski AM, Rossini A, Cymrot R. Algumas características da prática da automedicação em Campo Grande, Mato Grosso do Sul. Saúde Farmacológica 2000; (2): 4-10.

CEME. Memento Terapêutico CEME 89/90 - Relação Nacional de Medicamentos Essenciais - Rename e Relação de Medicamentos Básicos RMB. $2^{a}$ ed. Brasília (DF); 1989.

Centers for Disease Control, World Health Organization. Epi Info. Epidemiologia em microcomputadores: um sistema de processamento de texto, banco de dados e estatísticas [programa de computador]. Atlanta: OPAS / WHO; 1990.

Chapman CR. Pain, Perception, and Illusion. In: Sterbach R. The Psychology of Pain. New York: Raven Press; 1986. p. 153-79.

Chetley A. Medicamento Problema. $2^{\mathrm{a}}$ ed. Chimbote Perú: Oficina de Coordinación de AIS LAC; 1994. Dipirona; 171-82.

Ciancio S, Reynard A, Zielezny M, Mather M. A survey of drug prescribing practices of dentists. NYS Dental Journal 1989 january: 29-31.

Cooper SA, Desjardins PJ. Analgésicos de ação periférica (não-opióides). In: Neidle EA, Yagela JA. Farmacologia e terapêutica para dentistas. $3^{\mathrm{a}}$ ed. Rio de Janeiro: Guanabara Koogan; 1991. p. 236-49. 
Costa AM, Castro LLC de. Racionalidade da automedicação orientada em Campo Grande-MS. . Saúde Farmacológica 1999 julho (ed. esp.): 17-18.

Costa EMOD. Perfil de utilização de medicamentos por lactantes do município de Londrina - PR. Londrina; 1999. [Dissertação de Mestrado - Universidade Estadual de Londrina].

Costa MCN, Macedo JN, Hermógenes JA. Prescrição, dispensação e uso de medicamentos em dois centros de saúde de Salvador, Bahia. Revista Baiana de Saúde Pública 1992; 19 (1/4): 9-18.

Cunha MCN. Avaliação do uso de medicamentos na Rede Pública Municipal de Campo Grande - MS. Campo Grande (MS); 1999. [Dissertação de Mestrado Universidade Federal do Mato Grosso do Sul].

De Martínez P, Navarrete AE. Estudio del sistema de dispensación de medicamentos a pacientes ambulatorios del Hospital Rosales. Revista de la O.F.I.L. 1992; 2 (3): 154-9.

De Vries CS, Thomp TLFJ, Blijleven W, De Jong-van den Berg LTW. Prescription data as a tool in pharmacotherapy audit (I) General considerations. Pharm World Sci 1999a; 21(2): 80-4.

De Vries CS, Van den Berg PB, Timmer JW, Reicher A, Blijleven W, Thomp TLFJ, De Jong-van den Berg LTW. Prescription data as a tool in pharmacotherapy audit (II) the development of an instrument. Pharm World Sci 1999b; 21(2): 85-90.

Doering PL, Kerber LM. Aspectos teóricos do uso de medicamentos durante a gravidez e amamentação. Infarma 1993; 2(6): 8-11. 
Dunn JR. Dentist-prescribed home bleaching: current status. Compendium 1998; 19 (8): $760-4$.

Edwards R, Hugman B. The challenge of effectively communicating risk-benefit information. Drug Safety 1997; 17 (4): 216-27.

Ferreira MBC, Wannmacher L. Princípios gerais do uso correto dos antiinflamatórios. In: Wannmacher L, Ferreira MBC. Farmacologia clínica para dentistas. Rio de Janeiro: Guanabara Koogan; 1995a. p. 105-6.

Ferreira MBC, Wannmacher L. Princípios gerais do uso correto de antimicrobianos. In: Wannmacher L, Ferreira MBC. Farmacologia clínica para dentistas. Rio de Janeiro: Guanabara Koogan; 1995b. p. 121-3.

Ferreira MBC, Wannmacher L. Fármacos usados em emergências e urgências durante $o$ atendimento odontológico. In: Wannmacher L, Ferreira MBC. Farmacologia clínica para dentistas. Rio de Janeiro: Guanabara Koogan; 1995c. p. $178-181$.

Ferreira MBC, Wannmacher L. Processos mórbidos e medicamentos que influem na prática odontológica. In: Wannmacher L, Ferreira MBC. Farmacologia clínica para dentistas. Rio de Janeiro: Guanabara Koogan; 1995d. p. 200-4.

Fonseca MRCC. Uso de medicamentos na gravidez: uma abordagem farmacoepidemiológica. Campinas; 1998. [Dissertação de Mestrado - Faculdade de Ciências Médicas da Universidade Estadual de Campinas].

Fresle DA, Wolfheim C. Public education in rational drug use: a global survey. Geneva: World Health Organization; 1997. 
Fuchs FD. Dipyrone: the risk of agranulocytosis should restrict its use. Ciência e Cultura 1988; 40: 1089-91.

Gill PS, Mäkelä M, Vermeulen KM, Freemantle N, Ryan G, Bond C, Thorsen T, Haaijer-Ruskamp FM. Changing doctor prescribing behaviour. Pharm World Sci 1999; 21 (4): 158-67.

Gomes KRO, Moron AF, Souza e Silva R de, Siqueira AF de. Prevalência do uso de medicamentos na gravidez e relações com as características maternas. Rev Saúde Pública 1999; 33 (3): 246-54.

Hurd WW. Menopausa. In: Berek JS, editor. Tratado de Ginecologia. $12^{\mathrm{a}}$ ed. Rio de Janeiro: Guanabara Koogan; 1998. p. 696-716.

Ishikawa AG. Condutas suicidas por medicamentos. Campo Grande (MS); 1997. [Dissertação de Mestrado - Universidade Federal do Mato Grosso do Sul].

Jones TC. Pharmacists, physicians and the delivery of health care. BJID 1999; 3: 201-2.

Kent G. Anxiety, Pain and Type of Dental Procedure. Behaviour Research and Therapy $1984 ; 22: 465-9$.

Lawney M. For the record. Understanding patient recordkeeping. NYSDJ 1995 june / july 40-8.

Lember M, Pikk A, Mattila K, Virjo I, Kermes R, Isokoski M. How Estonian and Finnish primary care doctors rate their need for common drugs. Eur $\mathbf{J}$ Clin Pharmacol 1997; 52: 437-40. 
Lifshitz A. La decisión terapéutica. Rev Med IMSS (Mex) 1995; 33: 439-44.

Linares RL, Carrilo RE, Gomez LR, Kroeger A. Materiales de ensenãnza sobre el suministro, prescripción y dispensación de medicamentos. Washington (DC): Organización Panamericana de la Salud; 1995. (OPAS - Serie Paltex para Ejecutores de Programas de Salud, 37).

López J. Médicos que dispensan y farmacéuticos que prescriben. ¿un beneficio o un riesgo ? Revista de La O.F.I.L. 1996; 6 (2): 81-7.

Lorenzetti BB, Ferreira SH. Mode of analgesic action of dipyrone: direct antagonism of inflammatory hyperalgesia. Eur J Pharmacol 1985; 114: 375-81.

Loro ROC. Cuidados que deverão ser observados pelos cirurgiões-dentistas na prescrição de medicamentos. Revista Odonto Ciência 1986; 1 (1): 15-23.

Madrid I, Velázquez G, Fefer E. Pharmaceuticals and Health Sector Reform in the Americas: an Economic Perspective. Washington (DC): World Health Organization; 1998. The Economic Impact of Rational Drug Use; p. 71-9.

Maia LC, Valença AMG. Estudo comparativo do efeito da dipirona, paracetamol e ácido acetilsalicílico sobre o sistema cardiovascular, alívio da dor e sangramento em cirurgias odontológicas eletivas. Um estudo “in vivo". Âmbito Odontol 1994; 3: 316.

Marquez JO, Ferreira SH. Regional dipyrone nociceptor blockade: a pilot study. Braz J Med Biol Res 1987; 20: 441-44. 
Medal MDB, Robles JDR, Melchor DEC, Gimeno FJA, Sena MAM. Impacto de las prescripciones medicas de ambito ambulatorio sobre el hospitalario. Farm Hosp $1993 ; 17$ (4): 206-9.

Mendes GL. Interação Medicamentosa. RGO 1986; 34 (4): 345-8.

Mendes GL. Antimicrobianos de uso corrente em Odontologia. In: Wannmacher L, Ferreira MBC. Farmacologia clínica para dentistas. Rio de Janeiro: Guanabara Koogan; 1995. p. 124-36.

Miller CS, Hall EH, Falace DA, Jacobson JJ, Lederman DA, Segelman AE, Lexington Ky. Need and demand for oral medicine services in 1996. Oral Surg Oral Med Oral Path Oral Radiol Endod 1997; 84: 630-4.

Montgomery EH. Princípios e mecanismos da antibioticoterapia. In: Neidle EA, Yagela JA. Farmacologia e terapêutica para dentistas. $3^{\mathrm{a}}$ ed. Rio de Janeiro: Guanabara Koogan; 1991a. p. 397-411.

Montgomery EH. Antibióticos antibacterianos. In: Neidle EA, Yagela JA. Farmacologia e terapêutica para dentistas. $3^{\mathrm{a}}$ ed. Rio de Janeiro: Guanabara Koogan; 1991b. p. 412-446.

Murrah VA, Merry JW, Little JW, Jaspers MT. Compliance with guidelines for management of dental school patients susceptible to infective endocarditis. Journal of Dental Education 1987; 51 (5): 229-32.

Naylor GD, Fredericks MR. Pharmacologic considerations in the dental management of the patient with disorders of the renal system. Dental Clinics of North America 1996; 40 (3): 665-83. 
Neder AC. Manual de prescrição odontológica. São Paulo: American Med, 1995.

Neidle EA, Picozzi A. Farmacologia geriátrica. In: Neidle EA, Yagela JA. Farmacologia e terapêutica para dentistas. $3^{\mathrm{a}}$ ed. Rio de Janeiro: Guanabara Koogan; 1991. p. 539-544.

Nelson Júnior TE. Hemostasia, hemostáticos e anticoagulantes. In: Neidle EA, Yagela JA. Farmacologia e terapêutica para dentistas. $3^{\mathrm{a}}$ ed. Rio de Janeiro: Guanabara Koogan; 1991. p. 350-61.

Neutel CI. Drug utilizacion patterns as indicators. Pharmacoepidemiology and Drug Safety 1998; 7: 131-3.

Nunes AMC. Importância do Sistema de Farmacovigilância para o uso racional de medicamentos em Pediatria. CIM Informa, Boletim do Centro de Informações de medicamentos da UFMS 1997; 7: 4-6. [Apresentado à Jornada Sulmatogrossense de Pediatria; 1997 jun 18; Campo Grande].

Organização Mundial da Saúde. Cómo investigar el uso de medicamentos en los servicios de salud. Genebra, 1993a. n.7.

Organização Mundial da Saúde. CID-10. Tradução do Centro da OMS para a Classificação de Doenças em Português. São Paulo: Editora USP; 1993 b.

Palmer L, Lisk D. ¿ Quénes prescriben mejor, los médicos o los dispensadores de medicamentos ? Foro Mundial de la Salud 1997; 18: 381-3.

Paunovich ED, Sadowsky JM, Carter P. The most frequently prescribed medications in the elderly and their impact on dental treatment. Dental clinics of North America 1997; 41 (4): 699-726. 
Pawlicki RE. Psychological / Behavioral Techniques in Managing Pain and Anxiety in the Dental Patient. Anesth Prog 1991; 38: 120-7.

Pepe VLE. Estudo sobre a prescrição de medicamentos em uma unidade de atenção primária. Rio de Janeiro; 1994. [Dissertação de Mestrado - Centro Biomédico, Instituto de Medicina Social da Universidade do Estado do Rio de Janeiro].

Pinto MFR. Características da prescrição de medicamentos dos cirurgiõesdentistas que atuam na Rede Municipal de Saúde de Campo Grande. Campo Grande (MS); 1998. [Monografia de Especialização em Saúde Pública - Escola Nacional de Saúde Pública].

Pitrez JLB. Prescrição de medicamentos em Odontopediatria. In: Wannmacher L, Ferreira MBC. Farmacologia clínica para dentistas. Rio de Janeiro: Guanabara Koogan; 1995. p. 172-77.

Ramos DLP, Crosato E, Medeiros JMF. Aspectos éticos e legais da prescrição de medicamentos em odontologia. Odontólogo Moderno 1995; 22 (2): 6-8.

Ranali J, Andrade ED. O cirurgião-dentista e a importância da prescrição de medicamentos. Jornal da Associação Paulista de Cirurgiões-Dentistas 1998 jul.

Rolle C, Ferraco L, Matarazzo E, Ostino G. Change in precribing patterns of general practioners in Italy before and after the Reform Drug Act. A case study of changes in the city of Turin. Pharm World Sci 1995; 17(5): 158-62. 
Rösing CK. Quimioterapia antimicrobiana em periodontia. In: Wannmacher L, Ferreira MBC. Farmacologia clínica para dentistas. Rio de Janeiro: Guanabara Koogan; 1995. p. 150-3.

Rossini A, Castro LLC de. Qualidade dos Medicamentos usados na automedicação em Campo Grande, MS, agosto-dezembro de 1995. Saúde Farmacológica 1999 julho (ed. esp.): 16-17.

Santos V dos. Indicadores selecionados do uso de medicamentos - OMS, no município de Ribeirão Preto - SP. São Paulo; 1999. [Tese de Doutorado Faculdade de Saúde Pública da USP].

Sanz EJ, Bergman U, Dahlström M. Paediatric drug prescribing. A comparison of Tenerife (Canary Islands, Spain) and Sweden. Eur J Clin Pharmacol 1989; 37: 658.

Secretaria Municipal de Saúde de Vitória (ES). Memento Terapêutico. REMUNE. Relação Municipal de Medicamentos Essenciais. $1^{a}$ ed. Vitória (ES); 1998. p. 16371.

Silva JRO. Reações alérgicas aos antibióticos. Acidentes da pinicilinoterapia: prevenção e tratamento. Odontólogo Moderno 1996; 23 (3): 21-3.

Silva MA. Verso e reverso do medicamento. Automedicação, questão de educação em saúde ? Campo Grande; 1998. [Dissertação de Mestrado Universidade Federal de Mato Grosso do Sul]. 
Simões MJ, Filho AF, Cardoso RA. Avaliação do consumo de medicamento segundo a classe farmacológica. Revista da Faculdade de Ribeirão Preto 1986; 23 (2): 21923.

Sixel PJ, Lopes MB, Maia LC. Observações atuais da prescrição de medicamentos em Odontologia. Revista Brasileira de Odontologia 1995; 52 (1): 2-6.

Sousa VM. Automedicação em Odontologia. RGO 1996; 44 (6):327-9.

Spencer P. The dental higienist and the senior client. PROBE 1997; 31 (3): 89-91.

Thornhill MH, Duxbury AJ. Dental prescribing: missing the cost to the patient an the NHS. British Dental Journal 1996; 180 (3): 111-5.

Thyer B, Matthews J. The effect of phobic anxiety on plasma B-endorphine: a singlesubject experiment. Behaviour Research and Therapy 1986; 24: 237-41.

Trummel CL. Drogas antiinflamatórias. In: Neidle EA, Yagela JA. Farmacologia e terapêutica para dentistas. $3^{\mathrm{a}}$ ed. Rio de Janeiro: Guanabara Koogan; 1991. p. 25069.

Vicente MG, Vitorasso E, Girardi M, Lima SM, Barbosa ZM, Castro LLC de. Reações adversas a medicamentos em crianças internadas no Hospital Universitário / UFMS, no periodo de 1990 a 1997. Saúde Farmacológica 1999; jul: 9-15.

Wannmacher L, Ferreira MBC. Farmacologia clínica para dentistas. Rio de Janeiro: Guanabara Koogan; 1995a. Processos farmacocinéticos e suas aplicações na prescrição; p. 23-31. 
Wannmacher L, Ferreira MBC. Farmacologia clínica para dentistas. Rio de Janeiro: Guanabara Koogan; 1995b. Interaçð̃es medicamentosas; p. 38-41.

Wannmacher L, Ferreira MBC. Farmacologia clínica para dentistas. Rio de Janeiro: Guanabara Koogan; 1995c. Autacóides; p. 59-66.

Wannmacher L, Ferreira MBC. Farmacologia clínica para dentistas. Rio de Janeiro: Guanabara Koogan; 1995d. Princípios gerais do uso correto de fármacos para o tratamento da dor; p. 69-73.

Wannmacher L, Ferreira MBC. Farmacologia clínica para dentistas. Rio de Janeiro: Guanabara Koogan; 1995e.Analgésicos não-opióides; p. 90-4.

Wannmacher L, Ferreira MBC. Farmacologia clínica para dentistas. Rio de Janeiro: Guanabara Koogan; 1995f. Antiinflamatórios não-esteróides; p. 107-11.

Wannmacher L, Ferreira MBC. Farmacologia clínica para dentistas. Rio de Janeiro: Guanabara Koogan; 1995g. Uso de fármacos durante a gestação e a lactação; p. $169-71$.

Wannmacher L. A importância da Farmacologia Clínica para a terapêutica racional. In: Wannmacher L, Ferreira MBC. Farmacologia clínica para dentistas. Rio de Janeiro: Guanabara Koogan; 1995a. p. 3-4.

Wannmacher L. Antiinflamatórios esteróides. In: Wannmacher L, Ferreira MBC. Farmacologia clínica para dentistas. Rio de Janeiro: Guanabara Koogan; 1995b. p. 112-7. 
Westerlund T, Almarsdóttir AB, Melander A. Factors influencing the detection rate of drug - related problems in community pharmacy. Pharm World Sci 1999; 21 (6): 245-50.

Willison DJ, Gaebel KA, Borden EK, Levine MAH, Poston JW, Goldsmith CH, Wong B. Experience in the development of a postmarketing surveillance network: the pharmacy medication monitoring program. Ann Pharmacother 1995; 29: 120813.

World Health Organization. Guide to Good Prescribing. A practical manual. Geneva; 1994.

Wynn RL. The top 50 drugs dispensed in pharmacies in 1996. General Dentistry 1997 september / october: 416-7.

Yerro IP. Los perfiles terapéuticos como hierramenta de análiis de la prescripción. Revista de la O.F.I.L. 1993; 3 (5): 303-8.

Yohkoh N. Trends in the use of antibiotics in dental practice survey among 17 private dental colleges and university hospitals in Japan. Oral Therap and Pharmacol 1984; 3: 156-63.

Yohkoh N. Trends in the use of antimicrobial agents in dental practice survey among 29 dental colleges and university hospitals in Japan. Dentistry in Japan 1995; 32: 128-30. 


\section{BIBLIOGRAFIA COMPLEMENTAR}

Contandriopoulos AP, Champagne F, Potvin L, Denis JL, Boyle P. Saber preparar uma pesquisa. Definição. Estrutura. Financiamento. $2^{a}$ ed. Trad. Souza SR de. São Paulo / Rio de Janeiro: Editora Hucitec / Abrasco; 1997.

Gil AC. Como elaborar projetos de pesquisa. $3^{\mathrm{a}}$ ed. São Paulo: Editora Atlas; 1996.

Holanda Ferreira $\mathrm{AB}$ de. Novo Dicionário da Língua Portuguesa. $2^{\mathrm{a}}$ ed. Rio de Janeiro: Editora Nova Fronteira; 1986.

Jornal Brasileiro de Medicina. DEF Dicionário de especialidades farmacêuticas. $29^{a}$ ed. Rio de Janeiro: Editora de Publicações Científicas Ltda; 2000/2001.

Universidade de São Paulo. Faculdade de Saúde Pública. Biblioteca / CIR. Guia de apresentação de teses. São Paulo; 1998. 


\section{GLOSSÁRIO}

Ácido nucleico / ácido ribonucleico (RNA) - molécula envolvida na transcrição e tradução da informação genética, formada pela polimerização de unidades constituídas por um açúcar, um grupo fosfato e uma base nitrogenada.

Aeróbios - organismos que necessitam de oxigênio livre, retirado do ar, para viver.

Agranulocitose - síndrome caracterizada por neutropenia intensa, acompanhada, com muita freqüência, de baixa considerável da taxa total de leucócitos. Apresenta sinais clínicos de infecção, como febre alta, ulcerações em locais diversos (boca, reto, vagina etc.), e pode ter origens diversas, como, p. ex., medicamentosa.

Agregação plaquetária - aglomerado de plaquetas sangüíneas.

AMP cíclico - monofosfato cíclico de 3',5'- adenosina, mediador químico na indução de dor.

Anaerobicida - que destrói os organismos anaeróbios.

Anaeróbios - organismo que pode viver privado do contato do ar ou oxigênio livre.

Anamnese - informação acerca do princípio e evolução duma doença até à primeira observação do profissional de saúde.

Aparelhos ortodônticos - aparelho utilizado para prevenção e correção dos defeitos de posição de dentes e problemas faciais associados.

Aplasia celular - desenvolvimento incompleto ou imperfeito das células de um organismo.

Aspectos taxonômicos - aspectos relativos à classificação. 
Atividade simpática - atividade de um setor do sistema nervoso autônomo, que é uma porção do sistema nervoso, que inerva musculatura cardíaca e lisa, e controla secreções glandulares diversas. Não se encontra sob o controle da vontade.

Bacteremia - processo infeccioso generalizado, em que germes são veiculados pelo sangue sem, contudo, neste se multiplicarem.

Bactericida - que destrói as bactérias.

Bacteriostático - que evita a multiplicação bacteriana.

Bloqueador alfa-adrenérgicos - são fármacos que impedem a ação dos transmissores adrenérgicos sobre os receptores $\alpha$.

Bradicinina - substância endógena indutora de dor, que tem papel importante na regeneração de um tecido lesado.

Cardiopatias congênitas - afecções do coração que o indivíduo apresenta desde o nascimento.

Cárie dentária - dissolução e desintegração do esmalte e da dentina pela ação de bactérias acidificantes e de seus produtos.

Choque anafilático - reação exagerada do organismo a uma substtância a ele estranha, ou que já estivera em contato anteriormente.

Citopenia - baixa no número de células.

Citoprotetor - que confere proteção às células.

Concentrações plasmáticas - concentração do medicamento no plasma sangüíneo.

Concentrações séricas - Concentrações plasmáticas 
Concentrações terapêuticas - concentração plasmática, no local de ação de um princípio ativo, que permite obter o efeito terapêutico desejado.

Convertase - enzima.

Coronariopatas - pessoas com doenças referentes às artérias que irrigam o coração.

Denominação genérica - é o nome pelo qual o fármaco é conhecido mundialmente, sem considerar o fabricante. Este nome é escolhido pelos órgãos oficiais, que no Brasil são ligados ao Ministério da Saúde.

Dentaduras - dentes artificiais, devidamente montados.

Dentina - parte do dente que circunda a polpa dentária e está recoberta por esmalte, na coroa, e por cemento, na raiz.

Depósitos antígeno-anticorpo - os antígenos são substâncias capazes de, penetrando no organismo, provocar a formação de anticorpos. Estes por sua vez, são capazes de interagir com os antígenos que levaram à sua síntese.

Desequilíbrio eletrolítico - desequilíbrio de fenômenos químicos provocados pela passagem de corrente elétrica.

Desnaturação proteica - alteração das proteínas.

DNA / ácido desoxirribonucléico - molécula que contém a informação genética, formada por duas cadeias polinucleotídicas constituídas por um açúcar, um grupo fosfato e uma base nitrogenada.

Doença periodontal - qualquer condição mórbida do periodonto, que é o conjunto formado por osso em que está implantado um dente, formação ligamentar disposta em torno dele e cemento.

Dopamina - transmissor neural no sistema nervoso central. 
Dose - porção do medicamento que se toma de uma vez.

Edema - acúmulo anormal de líquido em espaço intersticial extracelular.

Efeitos adversos - todos os efeitos indesejados de um fármaco.

Efeitos colaterais - efeitos indesejáveis que ocorrem em tecidos diferentes do sítioalvo, mesmo com doses terapêuticas.

Efeitos metabólicos - efeitos no metabolismo, que é o conjunto de mecanismos químicos necessários ao organismo para a formação, desenvolvimento e renovação das estruturas celulares, e para a produção da energia necessária às manifestações interiores e exteriores da vida, bem como às reações bioquímicas.

Efetividade - resultado verdadeiro e real de um tratamento ou serviço.

Eficácia - propriedade de produzir o efeito desejado.

Eixo hipotálamo-hipófise-adrenal - eixo localizado no crânio.

Embolia pulmonar - obliteração de um vaso sangüíneo por um êmbolo, no pulmão.

Encefalopatia - cegueira por doença do nervo óptico, da retina.

Encistamento - formação de cavidade fechada onde se acumulam secreções que anormalmente não podem escoar-se.

Endocardite bacteriana - inflamação do endocárdio causada por infecção bacteriana.

Endógeno - originado no interior do organismo, ou por fatores internos.

Endorfina - neurotransmissor, substância opióide endógena.

Endotoxinas - toxinas originadas no interior do organismo, ou por fatores internos.

Epinefrina - adrenalina 
Éritema - rubor congestivo da pele, por via de regra temporário, que desaparece momentaneamente à pressão do dedo.

Especialidades farmacêuticas - preparação farmacêutica comercializada por um fabricante em uma dada embalagem e com marca registrada ${ }^{\circledR}$.

Estomatite - inflamação da membrana mucosa da boca.

Estudos de utilização de medicamentos (EUMs) - são aqueles que compreendem a comercialização, distribuição, prescrição, dispensação e uso dos medicamentos em uma sociedade, com especial enfoque em suas conseqüências sanitárias, sociais e econômicas.

Etiopatogênicos - início do desenvolvimento das doenças.

Exógeno - contrário a endógeno, externo, de fora.

Exsudato inflamatório - matéria resultante de processo inflamatório e que, saindo de vasos sangüíneos, se deposita em tecidos ou superfícies teciduais, constituída de líqüido, células, fragmentos celulares; caracterizada por alto conteúdo protéico.

Fagócitos - célula que realiza a fagocitose.

Fagocitose - ingestão e destruição de uma partícula sólida ou de um microrganismo por uma célula.

Fármaco - toda substância ou associação de substâncias utilizadas para modificar ou explorar sistemas fisiológicos ou estado patológico, para beneficio do receptor. É o mesmo que princípio ativo.

Farmacocinética - estudo do destino dos fármacos no organismo após sua administração e abrange processos de absorção, distribuição, biotransformação e excreção. 
Farmacodinâmica - consiste no estudo dos mecanismos de ação dos fármacos (alterações bioquímicas ou fisiológicas que modifica as funções celulares) e de seus efeitos no organismo (clinicamente observáveis ou mensuráveis).

Farmacoepidemiologia - estudo dos medicamentos como determinantes da saúde e da doença na população em geral.

Farmacovigilância - conjunto de procedimentos de deteç̧ão, de registro e de avaliação de reações adversas para determinação de sua incidência, de sua gravidade e de sua relação de causalidade com a forma e a dosificação de um medicamento ou fórmula magistral, com o objetivo último da prevenção, com base no estudo sistemático e pluridisciplinar das ações dos medicamentos.

Fatores quimiotáticos - substâncias que exercem influência química sobre as células.

Fenda labial ou palatina - defeito congênito, fenda nos lábios e/ou palato.

Fibrina - proteína esbranquiçada, insolúvel, que constitui a parte essencial do coágulo sangüíneo, e provém da ação da trombina sobre o fibrinogênio.

Forma farmacêutica - forma sob a qual o medicamento é administrado / consumido (por exemplo: comprimido, cápsula, drágea, suspensão oral, xarope etc.).

Gengivite - inflamação das gengivas.

Glomerular - referente a glomérulo, que é uma estrutura de filtração do rim.

Glossite - inflamação da língua

Gram-negativos - são as bactérias que não conservam a coloração (violeta-degenciana e lugol) a que são submetidas, após tratamento por álcool. A técnica foi desenvolvida pelo médico dinamarquês, Hans Christian Joachim Gram. 
Gram-positivos - são as bactérias que retém a coloração (violeta-de-genciana e lugol) a que são submetidas, após tratamento por álcool. A técnica foi desenvolvida pelo médico dinamarquês, Hans Christian Joachim Gram.

Granuloma - neoformação constituída por tecido de granulação, massa de tecido não tumoral, com características proliferativas, fibrosantes e degenerativas, que se desenvolve, muitas vezes, em diferentes inflamações crônicas.

Hemostáticos - medicamento contra as hemorragias.

Hiperalgesia - exagero da sensibilidade à dor.

Hipertemia - excessiva elevação da temperatura no organismo.

Hipoplasias dentárias - subdensenvolvimento dos tecidos dentais, por efeito de redução da proliferação celular.

Histamina - é uma substância natural do organismo, com ação vasodilatadora e constrictora dos músculos lisos.

Homeostática - relativo a tendência à estabilidade do meio interno do organismo.

Isquemia tecidual - suspensão ou baixa, localizada, de irrigação sangüínea nos tecidos.

Leucotrienos - são substâncias naturais do organismo, que aumentam a permeabilidade vascular e atraem leucócitos para o sítio da lesão.

Linfócitos - variedade de glóbulos brancos ou leucócitos que se origina nos tecidos reticulares dos nodos linfáticos.

Lisossomos - estrutura da molécula. 
Macrófagos - células do organismo que realizam a fagocitose, presentes no exsudato inflamatório.

Matriz conjuntiva - local de formação de tecido conjuntivo.

Medicamento - preparação farmacêutica utilizada para modificar ou explorar um sistema fisiológico ou um estado patológico, em benefício da pessoa que o recebe.

Migração leucocitária - migração de leucócitos (glóbulo branco do sangue).

Neuromoduladores - substâncias químicas sintetizadas em várias partes da célula nervosa, presentes em funções fisiológicas e processos patológicos. Atuam incentivando os mecanismos inibitórios.

Neuropatia periférica - doença nervosa do sistema nervoso periférico.

Neurotransmissores - substâncias químicas sintetizadas em várias partes da célula nervosa, presentes em funções fisiológicas e processos patológicos.

Neutropenia - baixa do número de leucócitos neutrófilos no sangue.

Nível histopatológico - à nível das estruturas microscópicas dos tecidos afetados.

Nível molecular - à nível das moléculas (grupamentos estáveis de dois ou mais átomos).

Nível periférico do Sistema Nervoso Central - células nervosas ou neurônios.

Nível sérico - concentração plasmática.

Nível talâmico e cortical - à nível do tálamo (porção do talamencéfalo que constitui a parte média e maior do diencéfalo e se localiza entre o epitálamo e o hipotálamo) e do córtex cerebral (camada externa do cérebro).

Nosográficos - relativo a nosografia, descrição metódica das doenças. 
Opióides endógenos - substâncias naturais do organismo, com efeito analgésico.

Parede celular - parede da célula dos microorganismos, não presente nas células dos mamíferos.

Patologia - modificações estruturais e/ou funcionais produzidas pela doença no organismo.

Periodontite - inflamação do periodonto (conjunto formado por osso em que está implantado um dente, formação ligamentar disposta em torno dele e cemento).

Polimorfonucleares - células cujos núcleos se apresentam sob forma de lóbulos, ou divididas de tal maneira que dá a impressão de serem múltiplas.

Posologia - indicação das doses em que devem ser aplicados os medicamentos.

Pré-puberal - periodo de passagem progressiva da infância para a adolescência.

Prescrição de medicamentos - é uma ordem escrita, com letra legível e em vernáculo, devidamente preenchida e assinada por médico, veterinário, enfermeiro, farmacêutico e dentista. Todos esses profissionais deverão estar inscritos e habilitados nos respectivos Conselhos Regionais, representativos de cada classe, devendo atuar em suas competências legais.

Prescrição racional - prescrição dos medicamentos indispensáveis, nas quantidades necessárias para alcançar os resultados desejados, no tratamento dos sintomas e das enfermidades dos pacientes.

Processo patológico - modificações estruturais e/ou funcionais produzidas pela doença no organismo.

Prostaglandina - substância natural do organismo, presente na maioria dos tẹcidos e fluidos orgânicos. Atua na vasodilatação, na sensibilização dos nociceptores e na 
estimulação dos centros hipotalâmicos de termorregulação, estando implicada na produção de febre.

Protocolo de atendimento - formulário regulador de determinado serviço de saúde.

Psicótica - relativo às doenças mentais.

Rash cutâneo - erupçð̃es cutâneas.

RNA-polimerase - enzima que atua no RNA.

Serotonina - neurotransmissor do sistema nervoso central, isto é substância química sintetizada em partes das células nervosas.

Síntese - operação química por meio da qual as células vivas fabricam as várias substâncias de que necessita o organismo a que pertencem.

Sítio-alvo - local onde se localiza dado processo patológico.

Survey analítico - estudo analítico voltado à descrição de situações e idéias, utilizando, principalmente, de questionários ou outros tipos de inquéritos.

Teratogenia - produção de malformação congênita.

Tópico - quando a administração do medicamento tem como finalidade, produzir efeitos locais.

Trismo - alteração motora dos nervos trigêmios, que impossibilita a abertura da boca.

Uso externo - inscrição utilizada quando o medicamento não é tomado e nem absorvido no trato gastrintestinal (vias inalatórias, injetáveis, tópicas etc.). 
Uso interno - inscrição utilizada toda vez que o medicamento é tomado e absorvido no trato gastrintestinal (via oral).

Uso parenteral - quando o medicamento é administrado sem utilizar o tubo digestivo.

Uso racional - é o uso do medicamento, na dose correta e pelo período necessário para assegurar sua eficácia. Implica em conhecimentos específicos e atualizados por parte dos profissionais e compreensão do paciente sobre a importância do tratamento.

Uso sistêmico - quando o medicamento administrado entra na circulação sanguiínea, com a finalidade de produzir efeitos generalizados em todo corpo.

Valvulopatias - doenças das válvulas cardíacas.

Vasodilatação arteriolar - vasodilatação das artérias.

Vasodilatação venular - vasodilatação das veias.

Via oral - quando o medicamento é administrado através do contato com qualquer segmento do trato digestivo (vias sublingual, bucal, oral e retal).

Vias de administração - são as estruturas orgânicas com as quais o fármaco toma contato para sofrer absorção.

Xerostomia - secura excessiva da boca. 


\section{ANEXO 1 - QUESTIONÁRIO DIRIGIDO AOS CIRURGIÕES-DENTISTAS}

Curso de Doutorado em Saúde Pública - Faculdade de Saúde Pública / Universidade de São Paulo

Elenir Rose Jardim Cury Pontes - Campo Grande / 2000

Prezado (a) colega,

Garantindo seu anonimato, gostaria de contar com sua colaboração nesta pesquisa que está sendo realizada para conclusão de Curso de Doutorado em Saúde Pública. O questionário abaixo contém perguntas objetivas e subjetivas. As perguntas objetivas devem ser respondidas assinalando com " $X$ " unicamente a alternativa escolhida. O questionário será recolhido amanhã, durante seu turno de trabalho. Favor colocá-lo no envelope fornecido que possui fitas auto-colantes, visto que só serão abertos no final da coleta.

Antecipadamente, muito obrigada.

\section{Questionário}

1- Quantos anos você tem de formado (a)?
A- Menos de 5 anos ( )
B- Entre 5 e 15 anos ( )
C- Mais de 15 anos ( )

2- Você fez ou está fazendo algum curso de pós-graduação à nível de especialização, mestrado ou doutorado? Sim ( ) Não ( )

3- Há quanto tempo você trabalha como Cirurgião (ã)-Dentista na Rede Pública de Campo Grande ?
A- Menos de 5 anos ( )
B- Entre 5 e $15 \operatorname{anos}($ )
C- Mais de 15 anos ( )

3.1- Faz plantões na Rede Pública de Campo Grande?

$\operatorname{Sim}()$

Não ( )

4- Você considera que o conteúdo oferecido na graduação foi suficiente para embasar suas prescrições? Sim ( )

Não ( )

5- Você costuma recorrer a algum auxílio, como livro, guia, cartilha, manual ou outro profissional, para prescrever medicamentos? $\quad$ Sim ( ) Não ( ) 
6- Você costuma participar de cursos relacionados à prescrição odontológica ?

$\operatorname{Sim}($ ) Não ( )

6.1- Participou de algum curso sobre prescrição odontológica nos últimos 12 meses?

Sim ( ) Não ( )

Caso tenha participado de algum curso, cite:

- Carga horária: horas

- Quem promoveu o referido curso:

7- A Prefeitura Municipal oferece algum tipo de auxílio, como guia, cartilha ou manual, para prescrição odontológica? Sim ( )

Não ( )

8- Você conhece a lista de medicamentos da Prefeitura Municipal ? Sim ( ) Não ( )

9- Você pede autorização ao médico para utilizar medicamentos em pacientes com algum problema de saúde (pressão alta, diabetes, cardiopatias etc.) ?

A- ( ) Sim, sempre

B- ( ) Quando necessário, a depender do quadro apresentado pelo paciente

C- ( ) Não, nunca

Por que?

10- Você pede autorização ao médico para utilização de medicamentos em mulheres grávidas ou que estão amamentando ?

A- ( ) Sim, sempre

B- ( ) Às vezes, dependendo do período gestacional 
C- ( ) Quando a gestante apresenta algum problema de saúde (pressão alta, diabetes, cardiopatias etc.)

D- ( ) Nas duas situações citadas anteriormente

E- ( ) Nunca

Por que?

11- Quando há emissão de autorização por escrito do médico, em relação à prescrição de medicamentos para pacientes com problemas de saúde ou mulheres grávidas ou que estão amamentando, você:

A- ( ) Sempre segue as orientações médicas, independentemente se concorda ou não com as orientações dadas.

B- ( ) Volta a questionar o médico, se não concorda com alguma orientação.

C- ( ) Não leva em conta as orientações fornecidas pelo médico.

Por que?

12- Você tem disponíveis dados sobre a saúde geral do paciente do prontuário médico da Unidade de Saúde, no momento do atendimento odontológico ? $\operatorname{Sim}($ ) Não ( )

Por que? 
13- Você registra o diagnóstico e os medicamentos prescritos após o atendimento odontológico ? (Esta pergunta não se refere aos procedimentos odontológicos, visto que estes são sempre registrados)

$\operatorname{Sim}()$

Não ( )

Por que?

14- Marque a alternativa que contém os medicamentos e as respectivas posologias que você receitaria para o manejo dos seguintes casos:

OBS.: Considere que a medicação seja prescrita após o tratamento clínico realizado. 14.1- Mulher de 25 anos, grávida de 5 meses, alérgica à penicilina, queixa de dor pulsátil e sensação de dente crescido, apresentando um diagnóstico de periodontite apical aguda de origem infecciosa. Considere que a medida clínica adotada seja a drenagem do exsudato via canal, curativo e selamento do dente com cimento provisório:

A- ( ) Penicilina G. Benzatina 1.200.000UI Frasco/Ampola (1 injeção I.M. dose única) + Dipirona 500mg/ml gotas (25 a 30 gotas de $6 \mathrm{em} 6$ horas).

B- (X) Eritromicina $250 \mathrm{mg} /$ comprimidos (1 comprimido de 6 em 6 horas) + Dipirona $500 \mathrm{mg} / \mathrm{ml}$ gotas ( 25 a 30 gotas de $6 \mathrm{em} 6$ horas).

C- ( ) Ampicilina $250 \mathrm{mg} / 5 \mathrm{ml}$ suspensão ( $5 \mathrm{ml}$ de $6 \mathrm{em} 6$ horas) + Ácido Acetil Salicílico $500 \mathrm{mg}$ / comprimidos (1 comprimido de 6 em 6 horas).

D- ( ) Eritromicina $250 \mathrm{mg} /$ comprimidos (1 comprimido de $8 \mathrm{em} 8$ horas) + Diclofenaco Sódico $50 \mathrm{mg} /$ comprimidos (1 comprimido de $8 \mathrm{em} 8$ horas).

E- ( ) Ampicilina $500 \mathrm{mg} /$ comprimidos (1 comprimido de 6 em 6 horas) + Diclofenaco Sódico $50 \mathrm{mg} /$ comprimidos (1 comprimido de $8 \mathrm{em} 8$ horas).

14.2- Criança de 7 anos, $30 \mathrm{~kg}$, apresenta quadro febril e dor, com diagnóstico de abscesso apical agudo e presença de tumefação localizada. Considere que o tratamento adotado seja a drenagem do abscesso por incisão: 
A- ( ) Diclofenaco Sódico $50 \mathrm{mg} /$ comprimidos (1 comprimido de $8 \mathrm{em} 8$ horas) + Dipirona $500 \mathrm{mg} / \mathrm{ml}$ gotas (12 gotas de $8 \mathrm{em} 8$ horas).

B- (X) Ampicilina $250 \mathrm{mg} / 5 \mathrm{ml}$ suspensão (6 ml de 6 em 6 horas) + Dipirona $500 \mathrm{mg} / \mathrm{ml}$ gotas (12 gotas de $6 \mathrm{em} 6$ horas).

C- ( ) Penicilina G. Benzatina 600.000UI Frasco/Ampola (1 injeção I.M. dose única) + Ácido Acetil Salicílico $100 \mathrm{mg} /$ comprimidos (1 comprimido de $8 \mathrm{em} 8$ horas).

D- ( ) Eritromicina $250 \mathrm{mg} /$ comprimidos (1 comprimido de $8 \mathrm{em} 8$ horas) + Dipirona $500 \mathrm{mg} / \mathrm{ml}$ gotas (30 gotas de $6 \mathrm{em} 6$ horas).

E- ( ) Ampicilina $500 \mathrm{mg} /$ comprimidos (1/2 comprimido de 6 em 6 horas) + Diclofenaco Sódico $50 \mathrm{mg} /$ comprimidos (1/2 comprimido de 8 em 8 horas).

14.3- Homem de 30 anos, diabético, com dor desde a realização de uma extração dois dias antes, e infecção localizada num alvéolo, definindo um diagnóstico de alveolite. Considere que o procedimento escolhido seja a curetagem e limpeza do alvéolo:

A- ( ) Ácido Acetil Salícílico $500 \mathrm{mg} /$ comprimidos (1 comprimido de $6 \mathrm{em} 6$ horas);

B- ( ) Eritromicina $250 \mathrm{mg} /$ comprimidos (1 comprimido de $8 \mathrm{em} 8$ horas);

C- ( ) Diclofenaco Sódico $50 \mathrm{mg} /$ comprimidos (1 comprimido de 6 em 6 horas) + Dipirona $500 \mathrm{mg} / \mathrm{ml}$ gotas ( 25 a 30 gotas de 6 em 6 horas)

D- ( ) Ampicilina $500 \mathrm{mg} /$ comprimidos (1 comprimido de $6 \mathrm{em} 6$ horas) + Ácido Acetil Salicílico $500 \mathrm{mg} /$ comprimidos ( 1 comprimido de 6 em 6 horas).

E- (X) Ampicilina $500 \mathrm{mg} /$ comprimidos (1 comprimido de 6 em 6 horas) + Dipirona $500 \mathrm{mg} / \mathrm{ml}$ gotas (25 a 30 gotas de 6 em 6 horas).

14.4- Das alternativas abaixo, assinale uma que contém substâncias contraindicadas, isto é, que não devem ser prescritas para mães que estão amamentando:
A- ( ) Tetraciclina, Dipirona
B- ( ) Penicilina, Dipirona
C- ( ) Tetraciclina, Ácido Acetil Salicílico
D- (X) Tetraciclina, Metronidazol
E- ( ) Penicilina, Diclofenaco 


\section{ANEXO 2 - QUESTIONÁRIO DIRIGIDO AOS PACIENTES}

Estamos realizando uma pesquisa sobre o serviço que é oferecido para o Senhor(a) neste Centro de Saúde.

Tente lembrar o que o Senhor(a) conversou com o Dentista, durante a consulta !

Por favor, responda as perguntas, é muito importante!

Coloque corretamente o número de matrícula, é o que tem na carteira do posto.

Nome completo:

Matrícula: Data de nascimento:

1 Por que o Senhor(a) veio ao Dentista?

2 O (a) Senhor (a) tem algum outro problema de saúde, a não ser este problema no dente?
( ) Sim
( ) Não

2.10 Dentista perguntou se o (a) Senhor (a) tem algum outro problema de saúde, a não ser este problema no dente?

( ) Sim ( ) Não

30 (a) Senhor (a) já passou mal depois de tomar algum remédio ?
( ) Sim
( ) Não 
3.1 O Dentista perguntou se o (a) Senhor (a) já passou mal depois de tomar algum remédio?

$$
\text { ( ) } \operatorname{Sim}(\text { ) Não }
$$

4 O (a) Senhor (a) faz uso, no momento, de algum outro remédio que não está na receita?
( ) Sim
( ) Não

4.1 O Dentista perguntou se o (a) Senhor (a) faz uso, no momento, de algum outro remédio que não está na receita ?

( ) Sim ( ) Não

5 O Dentista explicou como se deve usar os remédios que ele receitou ?
( ) Sim
( ) Não

\section{SOMENTE PARA SENHORAS}

6 A Senhora está grávida ou amamentando ? ( ) Sim ( ) Não

6.1 O Dentista perguntou se a Senhora está grávida ou amamentando ?

( ) Sim ) Não 


\section{ANEXO 3 - IMPRESSO PARA CÓPIA E ANÁLISE DAS PRESCRIÇÕES ODONTOLÓGICAS}

Nome paciente:

Data nascimento:

Registro:

Via de administração / nome dos medicamentos / quantidade / posologia

2

3

4

Data prescrição:

Carimbo presente ( ) ausente ( )

CRO presente ( ) ausente ( )

Assinatura profissional presente ( ) ausente ( )

Legibilidade presente ( ) ausente ( ) 


\section{ANEXO 4 - POSOLOGIA}

\section{Quadro 14}

Medicamentos utilizados em atendimentos odontológicos e as respectivas posologias, Campo Grande - MS, 2000.

\begin{tabular}{|c|c|c|}
\hline Medicamento & Dose & $\begin{array}{l}\text { Intervalo entre } \\
\text { doses }\end{array}$ \\
\hline Ácido Acetil Salicílico 100 mg* & $\begin{array}{c}10 \mathrm{mg} / \mathrm{kg} \text { peso por } \\
\mathrm{vez}\end{array}$ & $6 / 6$ hs. ou $4 / 4$ hs. \\
\hline Ácido Acetil Salicílico $500 \mathrm{mg}$ & $500 \mathrm{mg}$ por vez & $4 / 4$ hs. \\
\hline $\begin{array}{l}\text { Ácido Tramexamico } 250 \mathrm{mg} \text { injetável } \\
\text { ampola } 5 \mathrm{ml}\end{array}$ & $250 \mathrm{mg}$ por vez & $\begin{array}{c}3 \text { ou } 4 \text { vezes por } \\
\text { dia }\end{array}$ \\
\hline Ampicilina $250 \mathrm{mg}$ & 1 a 2 g por dia & $6 / 6$ hs. \\
\hline Ampicilina $250 \mathrm{mg} / 5 \mathrm{ml}$ suspensão* & $\begin{array}{c}50 \text { a } 100 \mathrm{mg} / \mathrm{kg} \text { peso } \\
\text { por dia }\end{array}$ & $6 / 6$ hs. \\
\hline Ampicilina $500 \mathrm{mg}$ & 1 a 2 g por dia & $6 / 6$ hs. \\
\hline Cefalexina $250 \mathrm{mg} / 5 \mathrm{ml}$ suspensão* & $\begin{array}{c}25 \text { a } 50 \mathrm{mg} / \mathrm{kg} \text { peso } \\
\text { por dia }\end{array}$ & $6 / 6$ hs. \\
\hline Cefalexina $500 \mathrm{mg}$ & 1 a 2 g por dia & $6 / 6$ hs. \\
\hline Cloranfenicol $250 \mathrm{mg}$ & 1 a 2 g por dia & 6/6 hs. \\
\hline Diclofenaco $10 \mathrm{mg} / \mathrm{ml}$ gotas* & $\begin{array}{c}0,5 \text { a } 2 \mathrm{mg} / \mathrm{kg} \text { peso } \\
\text { por dia }\end{array}$ & $8 / 8$ hs. \\
\hline $\begin{array}{l}\text { Diclofenaco } 75 \mathrm{mg} \text { injetável ampola } 3 \\
\mathrm{ml}\end{array}$ & $75 \mathrm{mg}$ por dia & $\begin{array}{l}1 \text { ampola por dia, } \\
\text { não mais do que } \\
\text { dois dias }\end{array}$ \\
\hline Diclofenaco sódico $50 \mathrm{mg}$ & $150 \mathrm{mg}$ por dia & $8 / 8$ hs. \\
\hline Dipirona $500 \mathrm{mg}$ & $500 \mathrm{mg}$ por vez & $6 / 6 \mathrm{hs}$. \\
\hline \multirow[t]{2}{*}{ Dipirona $500 \mathrm{mg} / \mathrm{ml}$ gotas } & $\begin{array}{c}10 \mathrm{mg} / \mathrm{kg} \text { peso por } \\
\text { vez* }\end{array}$ & $6 / 6$ hs. \\
\hline & 20 a 25 gotas por vez & $6 / 6$ hs. \\
\hline Dipirona $500 \mathrm{mg}$ injetável ampola $2 \mathrm{ml}$ & $500 \mathrm{mg}$ por vez & $8 / 8$ hs. \\
\hline Eritromicina $2,5 \%$ suspensão* & $\begin{array}{c}20 \text { a } 50 \mathrm{mg} / \mathrm{kg} \text { peso } \\
\text { pordia }\end{array}$ & $6 / 6$ hs. \\
\hline Eritromicina $250 \mathrm{mg}$ & 1 a 2 g por dia & $6 / 6$ hs. \\
\hline Metronidazol $250 \mathrm{mg}$ & 1 a 2 g por dia & $8 / 8$ hs. \\
\hline \multirow[t]{2}{*}{ Paracetamol $200 \mathrm{mg} / \mathrm{ml}$ gotas } & $\begin{array}{c}6 \text { a } 10 \mathrm{mg} / \mathrm{kg} \text { peso } \\
\text { por vez* }\end{array}$ & 6/6 hs. \\
\hline & 25 a 50 gotas por vez & 6/6 hs. \\
\hline Paracetamol $500 \mathrm{mg}$ & $500 \mathrm{mg}$ por vez & $6 / 6$ hs. \\
\hline $\begin{array}{l}\text { Penicilina G Benzatina } 1.200 .000 \text { UI } \\
\text { frasco/ampola }\end{array}$ & 1.200.000 UI por vez & $\begin{array}{c}1 \text { ampola a cada } 7 \\
\text { dias }\end{array}$ \\
\hline Tetraciclina $250 \mathrm{mg}$ & 1 a 2 g por dia & $6 / 6$ hs. \\
\hline
\end{tabular}

Fonte: MENDES 1995, PITREZ 1995, WANNMACHER e FERREIRA 1995e, WANNMACHER e FERREIRA 1995f, ARMONIA e TORTAMANO 1998, SECRETARIA MUNICIPAL DE SAÚDE DE VITÓRIA (ES) 1998.

* Uso pediátrico 


\section{ANEXO 5 - TABELAS REFERENTES AO QUESTIONÁRIO DIRIGIDO} AOS PACIENTES

\section{Tabela 21}

Número de respostas dos pacientes em relação a se o cirurgião-dentista perguntou sobre terem ou não algum problema de saúde, durante o atendimento odontológico, em Unidades de Saúde de Campo Grande - MS, 2000.

\begin{tabular}{l|c|c|c|c}
\hline \multirow{2}{*}{ Problema de saúde } & \multicolumn{4}{|c}{ Se o cirurgião-dentista perguntou } \\
\cline { 2 - 5 } & NR $^{*}$ & Sim & Não & Total \\
\hline NR & 1 & 1 & 0 & 2 \\
\hline Sim & 1 & 24 & 42 & 67 \\
\hline Não & 6 & 84 & 165 & 255 \\
\hline Total & 8 & 109 & 207 & 324 \\
\hline
\end{tabular}

* NR = não respondeu a esta pergunta.

\section{Tabela 22}

Número de respostas dos pacientes em relação a se o cirurgião-dentista perguntou sobre terem ou não passado mal ao utilizarem algum medicamento, durante o atendimento odontológico, em Unidades de Saúde de Campo Grande-MS, 2000.

\begin{tabular}{l|c|c|c|c}
\hline \multirow{2}{*}{$\begin{array}{l}\text { Passar mal ao utilizar } \\
\text { algum medicamento }\end{array}$} & \multicolumn{4}{|c}{ Se o cirurgião-dentista perguntou } \\
\cline { 2 - 5 } & NR $^{*}$ & Sim & Não & Total \\
\hline NR & 0 & 3 & 1 & 4 \\
\hline Sim & 3 & 18 & 28 & 49 \\
\hline Não & 3 & 86 & 182 & 271 \\
\hline Total & 6 & 107 & 211 & 324 \\
\hline
\end{tabular}

* NR = não respondeu a esta pergunta. 


\section{Tabela 23}

Número de respostas dos pacientes em relação a se o cirurgião-dentista perguntou sobre estarem ou não utilizando algum outro medicamento, durante o atendimento odontológico, em Unidades de Saúde de Campo Grande - MS, 2000.

\begin{tabular}{l|c|c|c|c}
\hline \multirow{2}{*}{$\begin{array}{l}\text { Estar utilizando algum } \\
\text { outro medicamento }\end{array}$} & \multicolumn{5}{|c}{ Se o cirurgião-dentista perguntou } \\
\cline { 2 - 5 } NR* $^{*}$ & Sim & Não & Total \\
\hline NR & 3 & 0 & 2 & 5 \\
\hline Sim & 1 & 27 & 45 & 73 \\
\hline Não & 3 & 71 & 172 & 246 \\
\hline Total & 7 & 98 & 219 & 324 \\
\hline
\end{tabular}

* NR = não respondeu a esta pergunta.

\section{Tabela 24}

Número de respostas das pacientes" em relação a se o cirurgião-dentista perguntou sobre estarem ou não grávidas ou amamentando, durante $o$ atendimento odontológico, em Unidades de Saúde de Campo Grande - MS, 2000.

\begin{tabular}{l|c|c|c|c}
\hline \multirow{2}{*}{ Gravidez ou amamentação } & \multicolumn{4}{|c}{ Se o cirurgião-dentista perguntou } \\
\cline { 2 - 5 } & NR** $^{*}$ & Sim & Não & Total \\
\hline NR & 81 & 0 & 1 & 82 \\
\hline Sim & 1 & 5 & 12 & 18 \\
\hline Não & 2 & 40 & 78 & 120 \\
\hline Total & 84 & 45 & 91 & 220 \\
\hline
\end{tabular}

* Foram excluídos os questionários respondidos do sexo masculino, e do sexo feminino, as seguintes idades: $\leq$ a 12 anos e $>$ que 50 anos, devido ao ciclo reprodutivo da mulher (HURD, 1998).

** $\mathrm{NR}=$ não respondeu a esta pergunta 


\section{ANEXO 6 - FICHA DE ATENDIMENTO ODONTOLÓGICO}

FICHA DE ATENDIMENTO - PRONTUÁRIO

Matrícula: Documento: $\mathrm{RG}$ Data de Nascimento: / / Idade: Sexo:

Nome:

Tel :

Mãe ou Responsável:

Prontuário Antigo :

Endereço:

Bairro: Município: Campo Grande

CEP: $79100-000$

Assinatura do Paciente ou Acompanhante

ATENDIMENTO: em $/$ /

Recepção ocorrida às : hs.

Especialidade: 30 ODONTO

Registro Profissional Tipo do atendimento: OD

CRO

Nome do profissional

Observações de Diagnósticos:

Dente

Face

Procedimento Quantidade Assinatura/Carimbo do Profissional Responsável
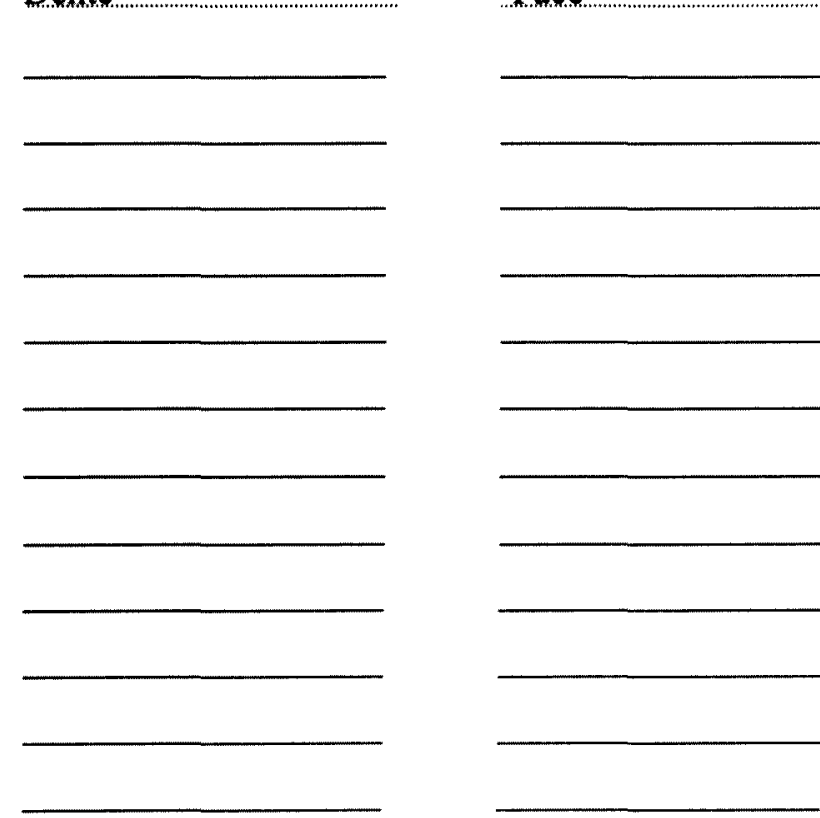